\author{
UNIVERSIDADE DE SÃO PAULO \\ FACULDADE DE ODONTOLOGIA DE BAURU
}

Avaliação longitudinal da inclinação axial mesiodistal dos molares superiores decorrente do uso do aparelho Pendulum associado ao aparelho fixo por meio de radiografias panorâmicas

CAROLINE ANDRADE ROCHA

BAURU

2010 



\section{Avaliação longitudinal da inclinação axial mesiodistal dos molares superiores decorrente do uso do aparelho Pendulum associado ao aparelho fixo por meio de radiografias panorâmicas}

Dissertação apresentada à Faculdade de Odontologia de Bauru da Universidade de São Paulo para obtenção do título de Mestre em Odontologia.

Área de concentração: Ortodontia

Orientador: Prof. Dr. Renato Rodrigues de Almeida

Versão corrigida 


\begin{tabular}{|c|c|}
\hline Rocha, Caroline Andrade & \\
R582a & Avaliação longitudinal da inclinação axial \\
mesiodistal dos molares superiores decorrente do uso \\
do aparelho Pendulum associado ao aparelho fixo por \\
meio de radiografias panorâmicas / Caroline Andrade \\
Rocha - Bauru, 2010. \\
159p. : il. ; $30 \mathrm{~cm}$ \\
Dissertação (Mestrado) -- Faculdade de \\
Odontologia de Bauru. Universidade de São Paulo. \\
Orientador: Prof. Dr. Renato Rodrigues de Almeida \\
\hline
\end{tabular}

Nota: A versão original desta dissertação encontra-se disponível no Serviço de Biblioteca e Documentação da Faculdade de Odontologia de Bauru - FOB/USP.

Autorizo, exclusivamente para fins acadêmicos e científicos, a reprodução total ou parcial desta dissertação, por processos fotocopiadores e outros meios eletrônicos.

Assinatura:

Data:

Projeto de pesquisa aprovado pelo Comitê de Ética em Pesquisa da Faculdade de Odontologia de Bauru, Universidade de São Paulo, em 24 de Junho de 2009.

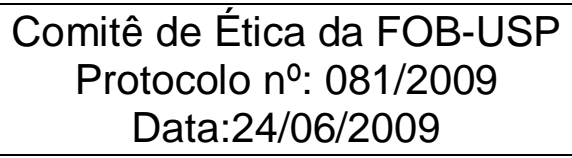




DADOS CURRICULARES

\section{CAROLINE ANDRADE ROCHA}

Nascimento

Filiação

$2004-2007$

$2008-2010$

$2009-2010$

Associações
12 de Dezembro de 1986

Assis - SP

Osvaldo Esperança Rocha

Miryam Cecília Gonçalves Andrade Rocha

Curso de Graduação em Odontologia pela Faculdade de Odontologia de Bauru da Universidade de São Paulo (FOB - USP)

Curso de Especialização em Ortodontia pela Uningá ACOPEN

Curso de Pós-Graduação em nível de Mestrado em Ortodontia, na Faculdade de Odontologia de Bauru, FOB - USP.

APCD - Associação Paulista de Cirurgiões-Dentistas 



\section{Dedicatóría}

Com todo o meu amor e gratidão

dedico este trabalho

à methor e mais amada mãe do mundo

Miryam Cecília Andrade Rocha 



\section{Agradeço a Deus}

Pela vida, pelo amor e por me acompanhar permanentemente.

Obrigada por me proporcionar momentos de intensa felicidade como a realização deste sonho. 



\section{Agradecimento especial}

Aos meus país, Miryam e Osvaldo, por todo o amor e dedícação

\section{Minha amada mãe,}

$\mathcal{N}$ ão tenho palavras para expressar o que você significa pra mim. Você é minha vida, minha methor amiga, minha alma gêmea, meu porto seguro. Agradeço todos os dias a Deus por ter me presenteado com um ser tão especial e dedicado. Você nunca poupou esforços pra me fazer a fitha mais amada e feliz do mundo. Sempre fez de tudo para que eu conseguisse realizar todos os meus sonfos. Me acompanhou em todos os passos da minha vida, dando o apoío e o carinho de que preciseí. Peço a Deus que continue te abençoando e iluminando com muita paz e saúde. Você sempre foi fundamental para tudo, sem você nada sería possivel. Muito obrigada pela total dedicação à minha formação profissional. Se estou aqui hoje é por você. $\mathcal{E}$ esta

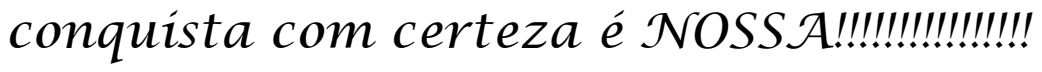

Te amo mais que tudo

\section{Meu querído paí,}

Muito obrigada por ser uma pessoa muito trabalhadora, um exemplo de garra e dedicação a tudo o que faz, não poupando esforços para atingir seus objetivos. Seu carinho, afeto e incentivo foram determinantes em minha existêncía.

Minha eterna gratídão a vocês 

Ao meu irmão Vitor

Mesmo que algumas vezes distante, sinto que posso contar com você. Obrígada pela sua amizade e incentivo.

\section{Ao meu amor}

Obrigada por todo amor e incentivo. Sem você ao meu lado, com certeza, tudo seria mais difícil. Você me presenteía com momentos de alegría, descontração e muito amor. Você me completa.

Te amo muíto!!

\section{À minha querida Nina}

Não posso deixar de te agradecer. Afinal, você é uma amiga muito especial. Sem palavras o seu olhar já diz tudo. Sua fiel companhia me faz muito bem. Você me ajudou muito nesta caminhada. Obrigada! 



\section{Agradecimento especial}

Ao meu orientador

Prof. Dr. Renato Rodrigues de $\mathcal{A l m e i d a}$

Pela ílustre orientação desta pesquisa, pela paciência e compreensão durante sua realização. Obrigada pela confiança depositada, pelos ensinamentos transmitidos, pelo convívio agradável e amizade transmitida.

Eu o admiro pela simplicidade, simpatía e profundos conhecimentos.

Foi uma honra ter um profissional humanista como meu orientador.

Meus sinceros agradecimentos. 



\section{Agradecimentos}

Ao Prof. Dr. Guitherme Janson, coordenador do curso de Mestrado em Ortodontía da FOB-USP, pela seriedade e dedicação com que conduziu todo o curso e pelos constantes ensinamentos, contríbuindo muito para minha formação científica. Minha sincera gratidão.

Ao Prof. Dr. Marcos Roberto de Freitas que, com sua simpatía e alegria, nos transmite os ensinamentos de Ortodontia de forma clara e objetiva. Minha eterna gratidão pelos votos de confiança depositados desde o início da especialização na Acopen. Obrígada por todo carinho e amizade.

À Prof. Dr $^{\mathrm{a}}$. Daniela Garib, por toda calma $e$ delicadeza com que ensina a Ortodontia. Obrigada por todo carinho e amizade que nos dedica.

Ao Prof. Dr. Arnaldo Pinzan, obrigada por todo o conhecimento transmitido e incentivo. Sua participação em minha formação foi extremamente valiosa.

Ao Prof. Dr. José Fernando Castanha Henriques, por toda atençâa e gentileza com que sempre trata os alunos e pelos valiosos ensinamentos. 

Aos funcionários da Disciplina de Ortodontia:

Vera, Sérgío, Wagner, Crís, Jeide e Daniel Bonné, pela amizade e pela constante disponíbilidade em nos ajudar. Muito obrígada!

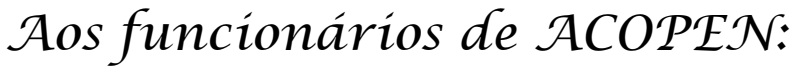

Lu e Dona Adélía, pela convívêncía prazerosa e por tanto carinho.

$\mathcal{A}$ minha querida turma de mestrado:

Amanda, Carolina, Daniel, Juliana, Laura, Manoela, Patrícia, Renata, Roberto, Suelen e Taiana

Obrígada pela amizade, aprendizagem e pela agradável convívêncía. Vocês foram muito importantes nesta etapa de minha vida. Contem sempre comigo!

A turma de doutorado pelo carinho e consideração, especialmente, ao Luiz Eduardo por toda disposição com que sempre me ajudou, com muita atenção, carinho e amizade. Sua ajuda foi essencial para esse trabalho. Muito obrigada! 

Às colegas do curso de especialização da ACOPEN:

Juliana, Susi, Kelen, Manoela, Rafaela e Manuela. Pelos inúmeros momentos de descontração e amizade. Os três anos de curso foram muito maís especiais ao lado de vocês.

Sentirei saudades...

À Profa. Dra $^{a}$. Karina Freitas, obrigada por toda sua atenção, paciência e amizade. Sempre disposta a ajudar, apoiando-me em todos os momentos de necessidade. Você é um exemplo de determinação! Obrigada por todo conhecimento transmitido. Sereí eternamente grata a você e toda sua família.

$\grave{\mathcal{A}}$ Prof $^{a}$. Dra . Renata Rodrigues de $\mathcal{A}$ lmeida, pelas inúmeras contríbuições na realização deste trabalho. 

ג̇ Faculdade de Odontologia de Bauru, Universidade de São Paulo, representada pelo Díretor, Prof. Dr. José Carlos Pereira

Ao Prof. Dr. Paulo César Rodrigues Conti, Presidente da Comissão de Pós-Graduação da Faculdade de Odontología de Bauru - USP

Aos funcionários da Pós-Graduação e Bíblioteca, pela atenção e carinho com que sempre me atenderam

Aos funcionários da Clinica de Radiologia, obrigada pela atenção e colaboração

Ao Prof. Dr. José Roberto Laurís, pela paciêncía e pelos ensinamentos de estatística

$\mathcal{A}$ todos os pacientes que foram essenciais para o meu aprendizado e para a realização deste trabalho

À CAPES, pela concessão da bolsa de estudos

E, a todos, que de alguma maneira, me auxiliaram nesta caminhada 

Resumo 



\section{RESUMO}

O objetivo deste estudo foi avaliar, por meio das radiografias panorâmicas, o comportamento longitudinal da inclinação axial mesiodistal dos molares superiores decorridos cinco anos após o tratamento realizado com o aparelho Pendulum seguido de aparelhagem ortodôntica fixa e comparar os resultados com os valores médios normais. A amostra consistiu de 20 pacientes (14 do gênero feminino e 6 , do masculino) com má oclusão de Classe II tratada por meio da distalização dos molares superiores. A média da idade, ao início do tratamento (T1), foi de 14,27 \pm 1,62 anos, ao final do tratamento (T2), 18,59 $\pm 1,82$ anos, e, cinco anos póstratamento (T3), 23,77 $\pm 2,04$ anos. A média do tempo de tratamento foi de 4,36 \pm 0,79 anos e de avaliação pós-tratamento foi de 5,18 $\pm 1,14$ anos. Como grupo controle, utilizou-se os valores angulares médios normais de molares superiores obtidos por Ursi (1989), sendo que essa obtenção partiu de radiografias panorâmicas de indivíduos com oclusão normal apresentando idades entre 12 e 17 anos. Para a análise estatística, utilizaram-se os traçados das radiografias panorâmicas nas 3 fases (T1, T2 e T3). Os dados obtidos foram analisados estatisticamente pelo teste ANOVA dependente seguido do teste de Tukey. As médias das inclinações axiais mesiodistais nas fases T1, T2 e T3 foram comparadas com os valores médios normais pelo teste $t$ independente. Os resultados apontaram que os primeiros molares superiores, ao término do tratamento ortodôntico, estavam mais inclinados para a distal, porém, cinco anos após, tenderam a verticalizarem-se naturalmente, voltando a ocupar uma posição próxima ao inicial. Quando comparados com os valores normais, somente o primeiro molar superior esquerdo apresentou, no período T2, valor estatisticamente significante diferente do normal. Os valores correspondentes para os segundos molares superiores não apresentaram estatisticamente significantes quando comparados entre si, nem quando comparados com os valores normais. O tratamento com o Pendulum seguido de aparelhagem ortodôntica fixa promove uma inclinação das coroas dos molares para a distal, tendendo esses dentes, entretanto, no longo tempo póstratamento, a verticalizarem-se.

Palavras-chave: Aparelho Pendulum. Radiografia Panorâmica. Inclinação axial mesiodistal. 

Abstract 



\section{ABSTRACT \\ Longitudinal evaluation of axial mesiodistal inclination in maxillary molars as a result of using the Pendulum device associated with fixed appliance, through panoramic radiographs}

The objective of this study was to evaluate, through panoramic radiographs, the longitudinal conduct of mesiodistal inclination in maxillary molars five years after the treatment performed with the Pendulum device followed by fixed appliance and compare the results with normal mean values. The sample consisted of 20 patients (14 female and 6 male) with Class II malocclusion treated with molar distalization. The average age at pretreatment (T1) was $14.27 \pm 1.62$ years, at posttreatment (T2), $18.59 \pm 1.82$ years and at the long-term posttreatment (T3) $23.77 \pm 2.04$ years. The average length of time of the treatment was $4.36 \pm 0.79$ years and the evaluation of the long-term posttreatment was $5.18 \pm 1.14$ years. As a control, it was used the normal mean angular values of molar obtained by Ursi (1989), and this achievement came from panoramic radiographs of subjects with normal occlusion ranging in age from 12 to 17 years. Panoramic radiographs were taken for statistic analysis in all 3 stages (T1, T2, T3). The obtained data were statistically analysed through ANOVA Test dependent followed by Tukey test. The mean mesiodistal axial inclinations stages T1, T2, T3 were compared with normal mean values by the independent $t$ test. The results showed that the first molars were more inclined to distal at posttreatment but five years later they tended to upright naturally, occupying the previous position, close to the original. When compared with normal values, only the left first maxillary molar showed in T2 a statistically different value to the normal. The correspondent values for the second maxillary molars did not show to be statistically significant when compared with each other, nor when compared with normal values. The treatment with the Pendulum, together with the orthodontic appliance, fosters an inclination of the molars to the distal, but tends to upright in the long-term posttreatment.

Key words: Pendulum appliance, Panoramic radiographs, Mesiodistal axial inclination 



\section{LISTA DE FIGURAS}

Figura 1. Fotografias intrabucais e radiografia panorâmica de uma paciente Classe II, divisão 1, antes do tratamento ortodôntico 88

Figura 2. Aparelho Pendulum instalado 89

Figura 3. Fotografias intrabucais e radiografia panorâmica da paciente ilustrada na figura 1 , após o término do tratamento ortodôntico.

Figura 4. Fotografias intrabucais e radiografia panorâmica da paciente ilustrada na figura 1 , cinco anos após 0 tratamento 92

Figura 5. Delimitação das estruturas dentoesqueléticas 93

Figura 6. Demarcação dos pontos de referência 94

Figura 7. Demarcação da linha de referência e longo eixo dentário. 95

Figura 8. Mensuração dos ângulos 95

Figura 9. Valores médios das inclinações axiais mesiodistais dos primeiros molares superiores direito (16) e esquerdo (26) 123

Figura 10. Valores médios das inclinações axiais mesiodistais dos segundo molares superiores direito (17) e esquerdo (27) 124 



\section{LISTA DE TABELAS}

Tabela 1. Médias, desvios-padrão, valor mínimo e máximo das idades inicial (T1), final (T2), pós-tratamento (T3), tempo de tratamento (T1-T2) e tempo pós-tratamento (T2-T3) do grupo Pendulum.

Tabela 2. Resultado para o cálculo do tamanho da amostra para diferença entre duas médias e um poder do teste de $80 \%$. 102

Tabela 3. Resultados do teste $t$ pareado e da fórmula de Dahlberg (1940), aplicados às variáveis 16, 26, 17 e 27, para estimativa dos erros sistemáticos e casuais, respectivamente $(\mathrm{N}=20)$ 102

Tabela 4. Resultados da análise estatística descritiva para a variável do primeiro molar direito, em todas as fases e períodos avaliados. 102

Tabela 5. Resultados da análise estatística descritiva para a variável do primeiro molar esquerdo, em todas as fases e períodos avaliados. 103

Tabela 6. Resultados da análise estatística descritiva para a variável do segundo molar direito, em todas as fases e períodos avaliados. 103

Tabela 7. Resultados da análise estatística descritiva para a variável do segundo molar esquerdo, em todas as fases e períodos avaliados. 103 

Tabela 8. Resultados da análise de variância (ANOVA) e teste de Tukey para as variáveis $16,26,17$ e 27 , entre os tempos inicial, final e cinco anos pós-tratamento (letras semelhantes significam que não há diferença estatisticamente significante).

Tabela 9. Valores médios normais (padrão) e desvios-padrão das inclinações axiais mesiodistais de cada dente, médias (média T1) e desvios-padrão (DP T1) dos valores das inclinações axiais obtidas na fase inicial (T1) do tratamento, valor de "t" e níveis de probabilidade de significância $(p)$. 104

Tabela 10 Valores médios normais (padrão) e desvios-padrão das inclinações axiais mesiodistais de cada dente, médias (média T2) e desvios-padrão (DP T2) dos valores das inclinações axiais obtidas na fase final (T2) do tratamento, valor de "t" e níveis de probabilidade de significância (p). 104

Tabela 11 Valores médios normais (padrão) e desvios-padrão das inclinações axiais mesiodistais de cada dente, médias (média T3) e desvios-padrão (DP T3) dos valores das inclinações axiais obtidas cinco anos pós-tratamento (T3), valor de " $\mathrm{t}$ " e níveis de probabilidade de significância $(p)$.

Tabela 12 Valores médios normais das inclinações axiais mesiodistais de cada dente, médias dos valores obtidos na fase inicial (T1), final (T2) e cinco anos póstratamento (T3). 105 



\section{SUMÁRIO}

1 INTRODUÇÃO

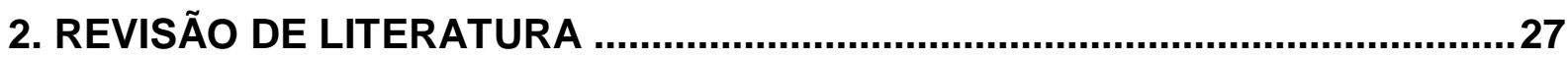

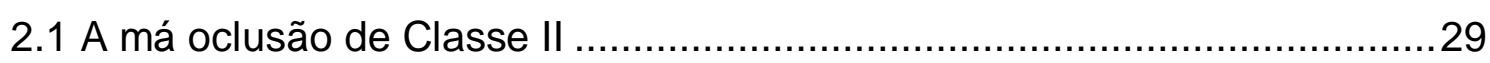

2.2 Tratamento da má oclusão de Classe II...................................................33

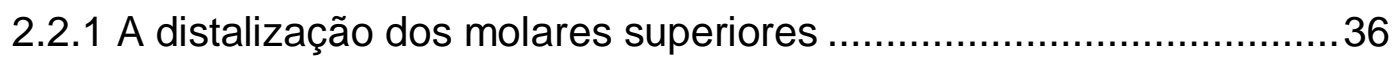

$2.3 \mathrm{O}$ aparelho Pendulum e as alterações promovidas ...................................39

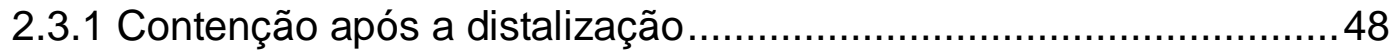

2.4 Estabilidade do tratamento da má oclusão de Classe II ..............................49

2.5 Considerações sobre a utilização da radiografia panorâmica

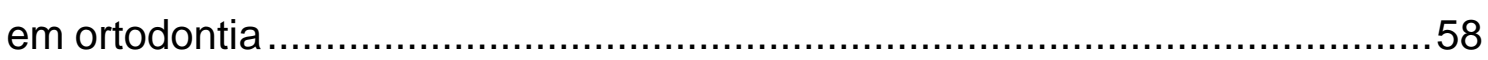

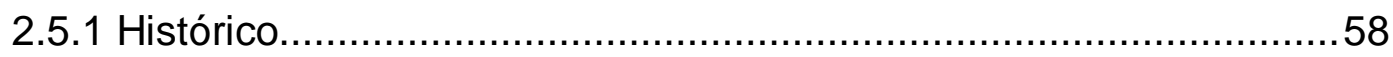

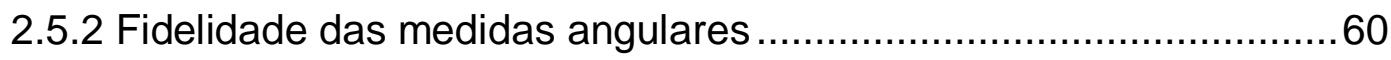

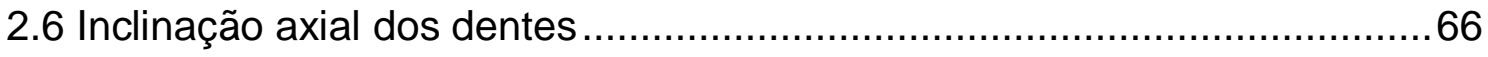

3. PROPOSIÇÃO

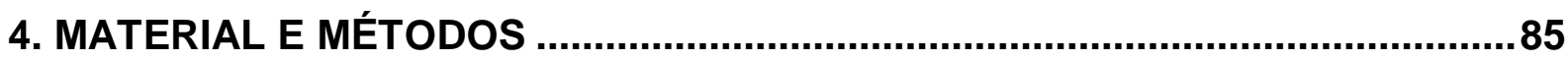

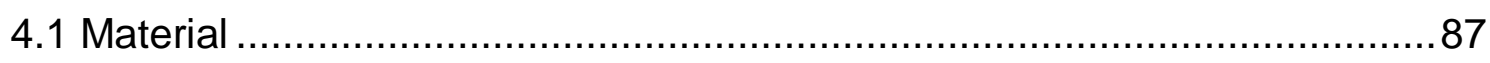

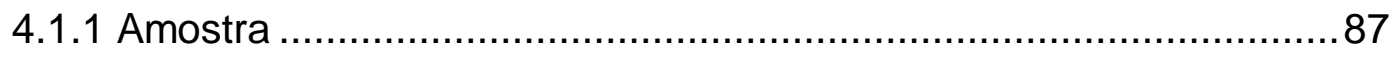

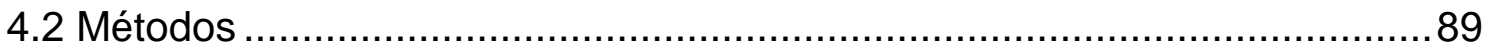

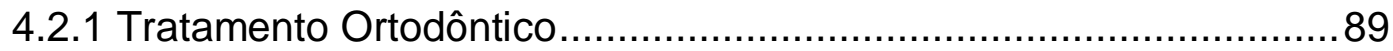

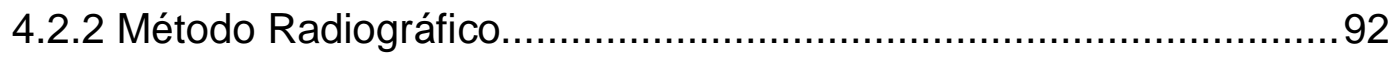

4.2.3 Elaboração do traçado.............................................................93

4.2.3.1 Delimitação das estruturas dentoesqueléticas .....................93

4.2.3.2.- Demarcação dos pontos de referência ...............................94

4.2.3.3 Demarcação da Linha de Referência e dos

Longos Eixos Dentários para Obtenção dos Ângulos .......................94

4.2.3.4- Mensuração dos ângulos ....................................................95 



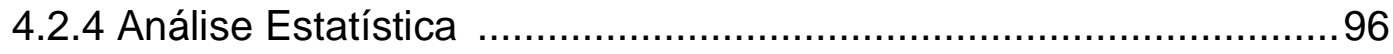

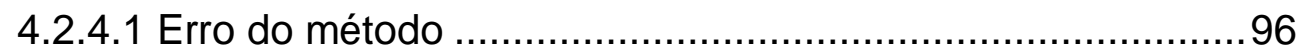

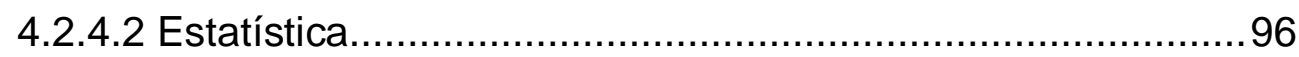

5. RESULTADOS

6. DISCUSSÃO

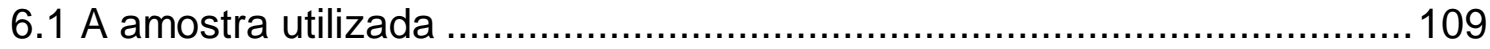

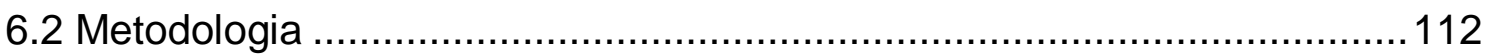

6.2.1 Radiografia panorâmica....................................................... 112

6.2.2 - Inclinação axial mesiodistal ................................................... 115

6.2.3 - Traçado de orientação..........................................................118

6.3 - Precisão da metodologia ..............................................................118

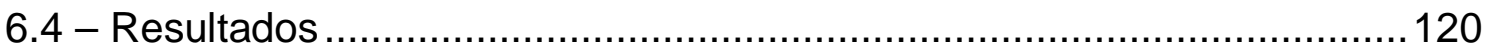

6.4.1 - Primeiros Molares Superiores Direito (16) e

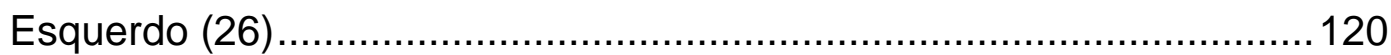

6.4.2 - Segundos Molares Superiores Direito (17) e

Esquerdo (27) ......................................................................... 123

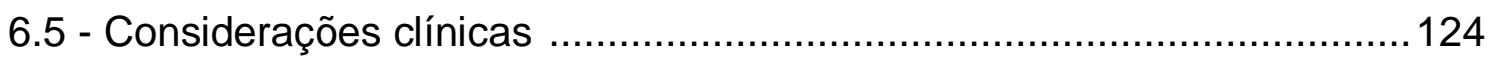

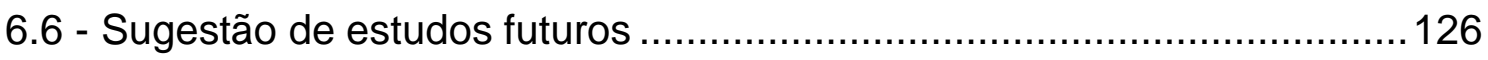

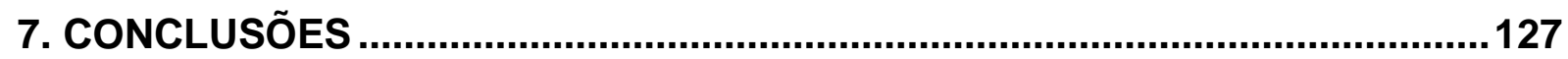

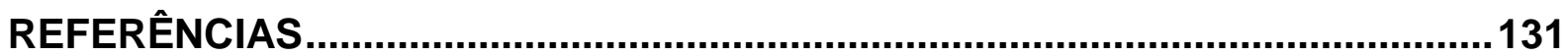

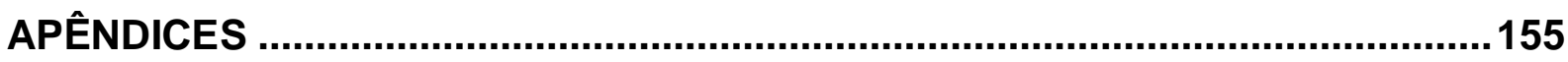

ANEXO 



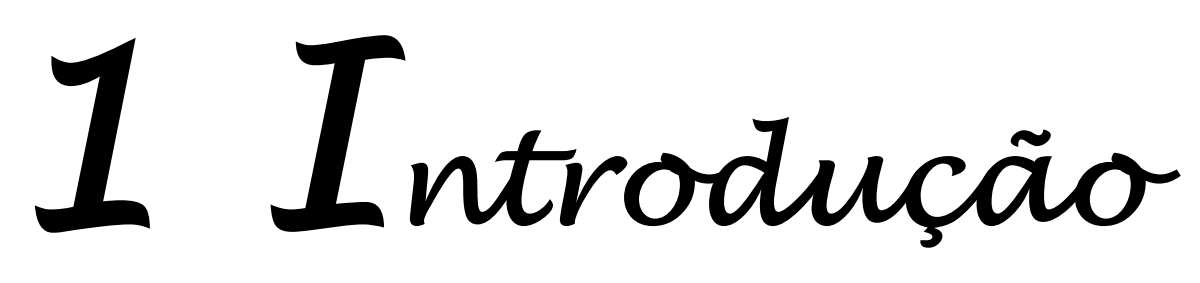





\section{INTRODUÇÃO}

O tratamento da má oclusão de Classe II sem comprometimento esquelético significativo consiste na distalização dos molares, pré-molares, caninos e incisivos superiores para uma relação molar normal, por meio dos aparelhos distalizadores de molares superiores (CETLIN; TEN HOEVE, 1983; MOYERS et al., 1980).

A não extração de pré-molares na correção de uma má oclusão de Classe II representa uma razão convincente para distalizar os molares superiores (SILVA FILHO et al., 2007). Inicialmente, preconizou-se a utilização do aparelho extrabucal (AEB) para a distalização dos molares superiores, rotineiramente empregado até os dias atuais (CIGER; AKSU; GERMEC, 2005). Com esse aparelho, é possível distalizar os primeiros molares superiores de corpo, fazendo com que a linha de ação de força passe pelo centro de resistência dos molares. Isso se obtém com a inclinação para cima do braço externo do aparelho extrabucal (AEB) (SILVA FILHO et al., 2007). Outra característica importante e exclusiva deste dispositivo é que ele apresenta as forças reacionais fora da boca, já que é um aparelho de ancoragem extrabucal, ou seja, os dentes somente respondem ao impacto da ação da força. Não respondem ao impacto da reação.

Apesar do conhecimento da sua eficácia na correção da má oclusão de Classe II, a utilização do aparelho extrabucal (AEB) pelos pacientes apresenta-se insatisfatória clinicamente, já que depende da colaboração direta dos mesmos (CLEMMER; HAYES, 1979; DORUK; AGAR; BABACAN, 2004). Segundo Clemmer e Hayes (1979) os pacientes utilizam o aparelho extrabucal em média $55,8 \%$ das horas recomendadas pelos ortodontistas.

Existem, entretanto, os aparelhos distalizadores intrabucais que independem da colaboração do paciente e que atuam induzindo um efeito dentário, sem influência esquelética. Dentre eles, destacam-se os aparelhos Pendulum, Distal Jet, Jones Jig, entre outros. Eles são considerados como um recurso prático para as correções dentárias anteroposteriores, visto que esses dispositivos promovem maior ganho de espaço no arco dentário superior e corrigem a relação molar de Classe II com redução da necessidade de colaboração do paciente (BRICKMAN; SINHA; NANDA, 2000; CARANO; TESTA, 1996; HILGERS, 1992; JONES; WHITE, 1992; 
NGANTUNG; NANDA; BOWMAN, 2001; PATEL et al., 2009). No entanto, os pacientes devem colaborar durante a mecânica de retração dos dentes anteriores, e correção da posição das raízes dos molares distalizados, geralmente, com a utilização de um aparelho extrabucal. O aparelho Pendulum foi desenvolvido por Hilgers em 1992. Sua eficácia na correção da relação molar de Classe II foi comprovada por vários autores (BUSSICK; MCNAMARA, 2000; BYLOFF; DARENDELILER, 1997; BYLOFF et al., 1997; CHAQUES-ASENSI; KALRA, 2001; FUZIY, 2001; GHOSH; NANDA, 1996; KINZINGER et al., 2000; KINZINGER et al., 2004). Vale salientar que essa movimentação se dá mais pela inclinação para distal da coroa do que pelo movimento de corpo do molar, já que, com a movimentação dos molares, a inclinação axial dos dentes se altera, com as coroas movendo-se mais distalmente do que as raízes, independentemente do tipo de distalizador utilizado, a explicação mecânica para a inclinação está na localização do ponto de aplicação da força em relação ao centro de resistência do molar e na impossibilidade em fazer com que a linha de ação de força passe pelo centro de resistência (ANGELIERI et al., 2006; BONDEMARK; KUROL, 1992; BRICKMAN; SINHA; NANDA, 2000; BUSSICK; MCNAMARA, 2000; BYLOFF; DARENDELILER, 1997; BYLOFF et al., 1997; CHAQUES-ASENSI; KALRA, 2001; FUZIY et al., 2006; GHOSH; NANDA, 1996; ITOH et al., 1991; JOSEPH; AUTCHART, 2000; RUNGE; MARTIN; BUKAI, 1999; SANTOS et al., 2007; SANTOS et al., 2006; SILVA FILHO et al., 2007). Na tentativa de evitar e corrigir a inclinação distal apresentada pelos molares são adicionadas dobras anti-inclinação de tal forma que o segmento intratubo forme um ângulo de $15^{\circ}$ em direção oclusal para se ter um maior controle sobre a inclinação distal das coroas dos molares e o uso do AEB noturno, cujo intuito é verticalizar as raízes.

A importância da obtenção de uma inclinação axial mesiodistal correta com as raízes paralelas entre si é frequentemente mencionada na literatura (ANDREWS, 1972; EDWARDS, 1971; GRABER, 1966; HATASAKA, 1976; HOLDAWAY, 1952; LEE, 1995; LUCCHESI; WOOD; NORTJE, 1988; MAYORAL, 1982; STRANG, 1952), porque o posicionamento dentário constitui um fator extremamente relevante para que a estabilidade do sistema estomatognático possa ser mantida por meio da neutralização das forças oclusais e da função normal (ROTH, 1981, 1987). O paralelismo radicular auxilia na manutenção do alinhamento dos dentes em suas bases apicais contribuindo para uma oclusão normal dos dentes superiores e 
inferiores (MAYORAL, 1982). Além disso, o correto posicionamento mesiodistal permite uma distribuição uniforme das forças oclusais por meio dos contatos proximais e contribuem sobremaneira na manutenção da estabilidade dos resultados obtidos pelo tratamento ortodôntico (EDWARDS, 1971; HATASAKA, 1976; MAYORAL, 1982).

A componente anterior de forças está intimamente relacionada com pontos de contatos dentários bem definidos, dependentes de uma inclinação axial mesiodistal correta e do relacionamento da oclusão de um dente contra dois dentes. Assim, a inclinação axial adequada deve estar incluída nos objetivos do tratamento ortodôntico, pois, além de tratar-se de um fator determinante para manutenção em longo prazo dos resultados atingidos com 0 tratamento, está diretamente relacionada com o alinhamento dentário (DEWEL, 1949).

A radiografia panorâmica é a mais utilizada para realizar a análise clínica do paralelismo radicular e da inclinação axial mesiodistal dentária, proporcionando condições satisfatórias para avaliação do posicionamento dentário antes, durante, ao término do tratamento e nos anos de acompanhamento pós-tratamento (ALMEIDA-PEDRIN; PINZAN; ALMEIDA, 2001; ALMEIDA-PEDRIN et al., 2006; ALMEIDA, 1999; CUOGHI; SELLA; MENDONÇA, 2010; LUCCHESI; WOOD; NORTJE, 1988; MAYORAL, 1982; SANTOS et al., 2006; SELLA; MENDONÇA; CUOGHI, 2009; SILVA FILHO et al., 2007; URSI et al., 1990; URSI, 1989).

Este trabalho visa avaliar longitudinalmente, através de radiografias panorâmicas, o comportamento da inclinação axial mesiodistal dos molares superiores decorrente do tratamento realizado com o aparelho Pendulum seguido de aparelhagem ortodôntica fixa e comparar com uma amostra de oclusão normal (URSI, 1989). 



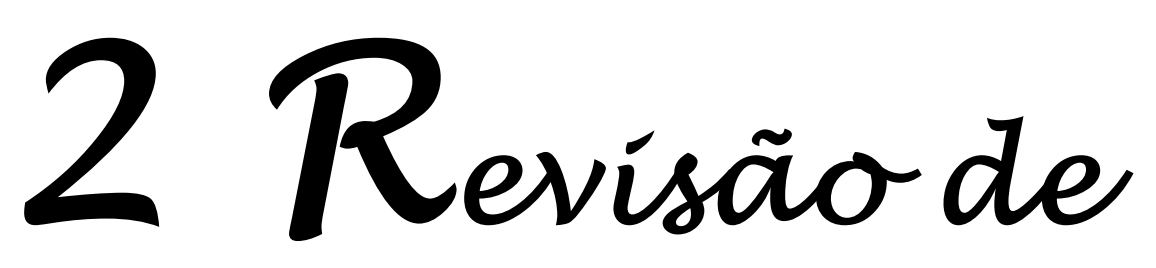

Literatura 



\section{REVISÃO DE LITERATURA}

Para uma melhor compreensão a revisão da literatura foi desenvolvida abordando os seguintes tópicos:

\subsection{A má oclusão de Classe II}

2.2 Tratamento da má oclusão de Classe II

2.2.1 A distalização dos molares superiores

2.3 $\mathrm{O}$ aparelho Pendulum e as alterações promovidas

2.3.1 Contenção após a distalização

2.4 Estabilidade do tratamento da má oclusão de Classe II

2.5 Considerações sobre a utilização da radiografia panorâmica em ortodontia

\subsubsection{Histórico}

2.5.2 Fidelidade das medidas angulares

2.6 Inclinação axial dos dentes

\subsection{A má oclusão de Classe II}

Angle (1907) definiu a má oclusão de Classe II como uma relação mesiodistal deficiente dos arcos dentários, com todos os dentes inferiores ocluindo distalmente em relação ao padrão normal, causando uma desarmonia acentuada dos incisivos e linhas faciais. Afirmou, também, que a obtenção da "oclusão normal" durante as fases da erupção dos dentes seria mais recomendada e poderia diminuir o período de contenção, além de admitir que o tempo de uso da contenção varia de acordo com a idade do paciente, a oclusão obtida, as causas da má oclusão, a quantidade do movimento dentário e a saúde dos tecidos moles (PROFFIT, 1994).

Com o advento da radiografia cefalométrica, observou-se que, além do determinante dentário, havia ainda fatores esqueléticos envolvidos no desenvolvimento da má oclusão de Classe II.

Assim, no decorrer do tempo, muitos autores procuraram estabelecer as principais características cefalométricas encontradas na Classe II, principalmente por essa má oclusão representar uma significativa porcentagem dos casos tratados nos consultórios odontológicos. De acordo com Massler e Frankel (1951) a proporção 
entre Classe I e Classe II, em um estudo da prevalência das más oclusões em adolescentes americanos entre 14 e 18 anos de idade, compreendeu 3:1, respectivamente. Em 1965, Ast et al. verificaram que 23,8\% dos estudantes do nível superior de Nova York possuíam a má oclusão de Classe II. Keski-Nisula et al. (2003) observaram uma prevalência de $33,1 \%$ do degrau distal em crianças finlandesas na dentadura mista. Em brasileiros, Silva Filho, Cavassan e Freitas (1989) encontraram uma frequência de $42 \%$ de Classe II, nas crianças naturais da cidade de Bauru - SP, na faixa etária de 7 a 11 anos.

Apesar da má oclusão de Classe I ser a mais prevalente na população, os aspectos antiestéticos da Classe II provocam o maior afluxo de pacientes em busca das correções estéticas e oclusais dessa oclusão irregular (GURGEL; ALMEIDA; PINZAN, 2001). Dentre os dois tipos de Classe II, a divisão 1 consiste na má oclusão mais frequente no meio ortodôntico (FREITAS et al., 2002).

Vários autores constataram que a má oclusão de Classe II, quando diagnosticada com base nas características oclusais, não se autocorrige em pacientes em crescimento. O padrão esquelético de Classe II se estabelece precocemente e se mantém até a puberdade, caso não haja intervenção ortodôntica (BACCETTI et al., 1997; HENRIQUES et al., 1998).

Bishara et al. (1995) ressaltaram em seu trabalho as características individuais da Classe II, divisão 1. Indicaram que os portadores dessa má oclusão apresentam uma maior sobressaliência horizontal, sobremordida profunda, maior ângulo ANB, incisivos superiores protruídos, convexidade facial aumentada, lábios protruídos e mandíbula retruída. Na Classe II, divisão 2, os incisivos superiores encontram-se retroinclinados, não havendo, no entanto, nenhuma diferença na morfologia dentoesquelética entre as más oclusões de Classe II, divisão 1 e 2 (PANCHERZ; ZIEBER; HOYER, 1997).

Com o objetivo de avaliar a frequência com que ocorrem as principais características da Classe II e a abordagem terapêutica mais adequada, McNamara Junior (1981) analisou telerradiografias em norma lateral de 277 crianças entre 8 e 10 anos. O autor observou que a má oclusão de Classe II pode resultar de várias combinações entre os componentes esqueléticos e dentários. Porém, as características mais prevalentes encontradas em sua amostra foram: posição maxilar retruída ou neutra; dentes anterossuperiores protruídos; retrusão 
mandibular; dentes anteroinferiores bem posicionados e desenvolvimento vertical excessivo do terço inferior da face.

As características cefalométricas de 50 jovens brasileiros possuindo Classe II, divisão 1, com idades variando de 9 a 15 anos, foram analisadas por Vale e Martins (1987). Observaram que a posição maxilar apresentou-se bastante variável, com discreta tendência ao prognatismo; os incisivos superiores apresentaram-se protruídos; a posição mandibular mostrou-se com grande variabilidade, com maior prevalência do retrognatismo mandibular; os incisivos inferiores apresentaram-se retruídos e houve um desenvolvimento vertical excessivo, representado pela altura facial anteroinferior aumentada.

Corroborando os resultados de McNamara Junior (1981), Karlsen (1994) verificou uma mandíbula retrognata e de comprimento diminuído, com acentuada tendência de subdesenvolvimento vertical dos molares superiores e inferiores, em pacientes possuindo Classe II, divisão 1, com ou sem sobremordida profunda.

Contudo, Rosemblum (1995) criticou severamente o estudo realizado por McNamara Junior (1981). O autor afirmou que as medidas mais confiáveis para o correto diagnóstico da Classe II baseiam-se no Plano de Frankfurt e não na linha SN (utilizada por McNamara Junior), as quais demonstraram prevalência da protrusão maxilar em $56,6 \%$ dos casos, contra $26,7 \%$ de retrusão mandibular, ao contrário dos dados apresentados por McNamara Junior (1981).

Henriques et al. (1998) avaliaram longitudinalmente 25 jovens apresentando má oclusão de Classe II, divisão 1 , dos 9 aos 12 anos, não tratados. Verificaram que, em $75 \%$ dos casos, a mandíbula apresentou-se retruída, enquanto a maxila variou entre retruída, bem posicionada e protruída. O padrão de crescimento denotou variabilidade, com distribuição uniforme de indivíduos com predominância de crescimento vertical, horizontal e equilíbrio dos vetores. Os incisivos superiores apresentaram-se geralmente protruídos e tenderam a perpetuar esta característica com o crescimento.

A grande maioria dos autores (CRAIG, 1951; HENRIQUES et al., 1998; KARLSEN, 1994; MARTIN, 1958; MCNAMARA, 1981; NELSON, 1953; OPPENHEIM, 1928; VIGORITO, 1973) afirma que há uma maior prevalência da retrusão mandibular na má oclusão de Classe II, em detrimento de uma maior protrusão maxilar, como comprovado mais recentemente por (BERTOZ, 2003; SANTOS, 2003). Bertoz et al. (2003) analisaram 55 jovens com má oclusão de 
Classe II, com idades variando entre 6 e 11 anos. Em 60\% da amostra, a maxila encontrou-se bem posicionada ou ainda retruída, e a mandíbula apresentou retrusão em relação à base do crânio. Verificou-se ainda que 60 a 70\% dos indivíduos analisados apresentaram crescimento vertical. Os incisivos superiores demonstraram uma tendência excessiva de vestibularização e protrusão, e os inferiores, em cerca de $50 \%$ da amostra, estavam vestibularizados, sendo que na outra metade apresentavam-se bem posicionados e protruídos. Já Santos (2003) observou em 55 jovens brasileiros, com média de idade de 13 anos e 6 meses, e má oclusão de Classe II, que: a maxila encontrava-se bem posicionada e a mandíbula retruída em relação à base do crânio; a mandíbula apresentava dimensão menor e a maxila normal; o padrão vertical apresentou-se preponderante, e os incisivos superiores e inferiores apresentaram-se inclinados para vestibular.

Com o intuito de comparar as más oclusões de Classe II, divisão 1 e Classe II, divisão 2, Pancherz, Zieber e Hoyer (1997) realizaram um estudo com crianças nas idades de 8 a 10 anos e 11 a 13 anos. Os resultados revelaram que ambas não são entidades clínicas simples e, com exceção da posição dos incisivos superiores, não se constatou nenhuma outra diferença morfológica entre elas. Independentemente da idade, ampla variação na morfologia dentoesquelética prevaleceu em ambas as más oclusões. Buscando um maior consenso na literatura, Hitchcock (1973) e Servoss (1975) afirmaram que as características cefalométricas observadas na Classe II, divisão 1, constituem-se numa combinação entre protrusão dos dentes anterossuperiores, prognatismo maxilar associada à retrusão mandibular.

Observa-se na literatura que os resultados pertinentes às características principais da Classe II divergem bastante. Já em 1953, Fisk et al. afirmaram que a má oclusão de Classe II poderia se apresentar em pelo menos seis situações: maxila protruída, dentes superiores protruídos, mandíbula subdesenvolvida, mandíbula com tamanho normal, mas retruída, dentes inferiores retruídos ou qualquer combinação dos fatores anteriormente citados, fato corroborado por Henry (1957). Ackerman e Proffit (1969) relataram que as más oclusões incluídas na mesma classificação de Angle (1899) poderiam ser somente análogas (mesmo relacionamento oclusal) e não necessariamente homólogas (com todas as características esqueléticas iguais). Assim, a má oclusão de Classe II pode estar associada a uma ou à combinação das seguintes condições: 
- protrusão maxilar esquelética adicionada ou não a um tamanho maxilar aumentado;

- protrusão dentária superior;

- retrusão mandibular esquelética associada ou não a uma mandíbula de tamanho diminuído;

- retrusão dentária inferior;

- ângulo da base do crânio obtuso.

A falta de consenso sobre as características dentofaciais da Classe II é um indicador da ampla variabilidade dentro da população (BISHARA et al., 1997). Sassouni (1970) analisando a maxila e a mandíbula nos sentidos horizontal e vertical, apresentou 128 variações da Classe II, com diferentes tipos de tratamento em consonância com tal variabilidade (BERTOZ, 2003). Esse aspecto torna-se compreensível à medida que diferentes interações entre os tecidos ósseos, dentários e moles levam à discrepância dentária descrita como distoclusão (BISHARA et al., 1997).

\subsection{Tratamento da má oclusão de Classe II}

Muitas terapias apresentam-se disponíveis aos ortodontistas para 0 tratamento da Classe II. Essas incluem os diferentes aparelhos extrabucais, aparelhos ortopédicos funcionais, diversos protocolos de extrações dentárias e os distalizadores de molares superiores (MCNAMARA, 1981; MOYERS et al., 1980). conhecimento e o correto diagnóstico da Classe II tornam-se imprescindíveis na medida em que cada aparelho difere nos efeitos promovidos na estrutura craniofacial, inclusive redirecionando o crescimento nas regiões envolvidas. Assim, as diferentes terapêuticas afetam a estrutura craniofacial de várias formas e a variedade disponível de aparelhos para 0 tratamento da Classe II reflete a diversidade de etiologias (MC DONALD, 1973). A escolha do melhor tratamento depende da idade e do diagnóstico preciso das alterações inerentes a cada paciente apresentando uma relação de Classe II dentária (MCNAMARA, 1981; MOYERS et al., 1980).

De maneira geral, diante de uma Classe II esquelética, em idade precoce e, preferencialmente, com padrão de crescimento equilibrado ou horizontal, indica-se o tratamento ortopédico. Se o fator problemático for a protrusão maxilar, pode-se 
empregar os diferentes tipos de aparelhos extrabucais (AEB), dependendo do padrão de crescimento do paciente; ou mesmo, na dentadura mista precoce, o splint maxilar ou AEB conjugado, com 0 intuito de restringir o crescimento maxilar (JOHNSON, 1994).

Se a Classe II estiver presente a expensas de uma retrusão mandibular, na fase de crescimento do paciente, indica-se o tratamento ortopédico que objetiva estimular o crescimento mandibular por meio dos aparelhos ortopédicos funcionais, que podem ser: ativador, bionator, Herbst, Bimler, dentre outros (JOHNSON, 1994; MCNAMARA, 1981).

Em idade mais avançada, na ausência de crescimento, uma Classe II esquelética acentuada somente será corrigida corretamente por meio da cirurgia ortognática associada ao tratamento ortodôntico. Porém, diante de uma Classe II esquelética de grau suave a moderado, e que, portanto, tolera uma "camuflagem ortodôntica", o tratamento de eleição será por meio das extrações. Geralmente, em se tratando da Classe II, o protocolo das extrações restringe-se somente aos primeiros pré-molares superiores ou conjuntamente aos segundos ou primeiros prémolares inferiores, na presença de apinhamento no arco dentário inferior (PROFFIT, 1994).

No decorrer do tempo, observa-se uma tendência bastante acentuada para um tratamento ortodôntico mais conservador, evitando-se ao máximo as extrações dentárias. Proffit (1994) comprovou uma diminuição estatisticamente significante nos índices das extrações dentárias realizadas na Universidade da Carolina do Norte, USA, entre 1968 e 1993. Em 1968, os tratamentos com extrações somavam 76\% dos casos tratados e, em 1993, somente $28 \%$. O declínio mais significativo ocorreu no tratamento da Classe I com apinhamento, sendo 50\% com extrações em $1963 \mathrm{e}$, aproximadamente, $10 \%$ em 1993. Já para o tratamento da Classe II, poucas alterações foram observadas, com índices não significantes estatisticamente, 16\% em 1968 e 8\% em 1993. Recentemente, vários autores têm proposto tratamentos para a Classe II de forma a evitar as extrações dentárias. De acordo com Moyers et al.(1980), Cetlin e Ten Hoeve (1983) e Gianelly (1998), para a Classe II dentária, sem comprometimentos esqueléticos significativos, o tratamento mais indicado consiste na retração de todos os dentes superiores para uma relação de molares, caninos e incisivos normais, sem alterações acentuadas na relação esquelética, na dimensão vertical ou comprometimento do arco dentário inferior. 
Quanto às contraindicações específicas das extrações, pode-se citar o tratamento de pacientes que ainda apresentam potencial de crescimento ativo dos maxilares e/ou estão com o desenvolvimento dentário incompleto e o tratamento de pacientes que apresentam padrão horizontal de crescimento com sobremordida excessiva, por haver maior dificuldade no fechamento dos espaços das extrações devido ao fato da musculatura peribucal se apresentar mais forte, além de aumentar a complexidade e o tempo de tratamento (ARVYSTAS, 1985; BELL; JACOBS; LEGAN, 1984).

Considerando a existência de várias formas de tratamento para a correção da Classe II, a seleção do protocolo dependerá, entre outros fatores, da época de intervenção, da gravidade da má oclusão, da falta de espaço nos arcos dentários superior, inferior ou em ambos e da idade do paciente (BRUSOLA, 1989; STRANG, 1957). A decisão pelo tratamento ortodôntico com ou sem extrações dentárias é guiada pela morfologia facial, pelo padrão de crescimento, pelo grau de motivação do paciente com o tratamento, pela magnitude da protrusão dos lábios, pela presença de apinhamento e pela estabilidade dos resultados obtidos com os tipos de tratamento disponíveis (BAUMIRIND, 1996; BISHARA; CUMMINS; JAKOBSEN, 1995; LITT; NIELSEN, 1984).

Um dos primeiros autores a abordar uma terapêutica sem extrações para 0 tratamento da Classe I e II com apinhamento e protrusão foram Cetlin e Ten Hoeve (1983). Os principais objetivos clínicos constituíam de obtenção de espaço nos arcos dentários superior e inferior, intrusão dos incisivos superiores e preservação da ancoragem máxima durante 0 tratamento, evitando-se efeitos adversos no crescimento facial. Para a obtenção de espaço no arco dentário inferior, foi utilizada uma placa lábioativa que agiu movimentando os molares distalmente, além de aumentar a dimensão transversal do arco dentário. No arco dentário superior, almejou-se o movimento de corpo para distal dos molares, essencial para evitar as recidivas para mesial. Para isso, utilizou-se de um aparelho removível com molas digitais de uso contínuo nos primeiros molares superiores, associado a um AEB de uso noturno, tração baixa ou alta, dependendo do padrão esquelético do paciente. A distalização dos molares levou, em média, 10 meses, com a colaboração fundamental do paciente. Após a obtenção dos espaços no arco dentário, os incisivos superiores foram retraídos e intruídos. Os autores concluíram que o tratamento sem extrações, quando bem indicado, proporciona ótimos resultados no 
que tange à estética, função, estabilidade e saúde bucal, sem alterar negativamente o potencial de crescimento facial.

Para a realização do tratamento das más oclusões de Classe II sem extrações dentárias, pode-se optar pelo emprego de aparelhos extrabucais (ARVYSTAS, 1985; GRABER, 1955; HERSCHCOPF, 1990), dos distalizadores intrabucais (BOLLA et al., 2002; CARANO; TESTA, 1996; JONES; WHITE, 1992), dos aparelhos fixos associados aos elásticos de Classe II (NELSON; HANSEN; HAGG, 1999; WEBER, 1971) ou dos aparelhos ortopédicos, em pacientes que ainda apresentam expressivo potencial de crescimento (DERRINGER, 1990; JANSON et al., 2004; JOHNSTON, 2002). Contudo, quando não há crescimento e nota-se uma deficiência mandibular severa associada a um padrão de crescimento vertical, pode ser necessária uma abordagem cirúrgica para garantir estética facial agradável, função normal e estabilidade das correções (FOGLE et al., 2004; SCOTT CONLEY; JERNIGAN, 2006).

A utilização de ancoragem absoluta como dos mini-implantes, das miniplacas entre outros elimina completamente a necessidade de colaboração e parece ser uma alternativa útil a esse problema, sendo indicada também para o tratamento da Classe II em pacientes adultos, pois estes podem se apresentar relutantes à utilização de aparelhos antiestéticos (BLOCK; HOFFMAN, 1995; CELENZA; HOCHMAN, 2000; ROBERTS; MARSHALL; MOZSARY, 1990).

Segundo Valarelli (2006) a proporção de sucesso do tratamento da Classe II sem extração é maior, quanto menor for a severidade da má oclusão inicial.

\subsubsection{A distalização dos molares superiores}

Gianelly (1998) afirmou que a distalização caracteriza-se pela movimentação para distal dos molares superiores, no estágio inicial do tratamento, para converter a relação molar de Classe II em I. O próprio autor atentou, em entrevista realizada em 1996, que, na presença de apinhamento na dentadura permanente associado a uma Classe I ou II, o tratamento por meio das extrações torna-se preferível, a menos que o perfil facial e/ou a profundidade da sobremordida o contraindique (GIANELLY, 1996). Na má oclusão de Classe II, com o arco dentário inferior em condições aceitáveis, pode-se iniciar o tratamento com a distalização dos molares superiores. Se não se observar progresso, parte-se então para a extração dos pré-molares 
superiores, exceto nos casos onde o perfil facial e a sobremordida profunda contraindiquem esse procedimento.

Os distalizadores intrabucais (Distal Jet, Jones Jig, Pendulum e outros) são indicados para a correção das más oclusões de Classe II dentárias e são descritos como vantajosos por não requererem a colaboração do paciente para que a distalização dos molares superiores ocorra com sucesso. Entretanto, não promovem total eliminação da necessidade de colaboração dos pacientes. Esses aparelhos, de modo geral, promovem a distalização e inclinação da coroa dos molares superiores, associada a uma mesialização e inclinação dos dentes de ancoragem, protrusão dos incisivos e aumento da altura facial anteroinferior (ALMEIDA et al., 2000).

O movimento distal dos primeiros molares superiores torna-se facilitado quando realizado antes da irrupção dos segundos molares superiores. Devido a isso, a época favorável para distalizar os molares compreende o período da dentadura mista. Indicam-se forças contínuas para a movimentação, já que essas movimentam os dentes mais rapidamente que as forças intermitentes. A quantidade de movimentação obtida encontra-se na proporção aproximada de $1 \mathrm{~mm} / \mathrm{mês}$, embora haja uma grande variação individual. Contudo já se sabe que os molares se movimentam basicamente por meio de inclinação axial da coroa para distal. Se os molares forem movimentados de corpo ao longo de um fio rígido, sua proporção de movimentação diminui para $0,5 \mathrm{~mm} / \mathrm{mês}$. Isso sugere que um fator que influi na proporção da distalização é o tipo de movimentação. O movimento mais rápido ocorre quando o molar é inclinado para distal. Contudo, se os segundos molares não se apresentarem irrompidos, a proporção aumenta para mais de $1 \mathrm{~mm} / \mathrm{mês}$ (GIANELLY, 1998).

A distalização deve prosseguir até que os molares atinjam uma sobrecorreção de aproximadamente 2mm (GIANELLY, 1998). A sobrecorreção é necessária por duas razões principais:

- a perda de ancoragem invariavelmente ocorre durante a retração dos pré-molares, caninos e incisivos, e a sobrecorreção serve para compensar essa perda de ancoragem. Em outras palavras, a sobrecorreção constitui-se num "preparo de ancoragem" (GIANELLY, 1998);

- os molares distalizados geralmente se movimentam pela inclinação para distal, com a movimentação maior da coroa do que da raiz. Após a sobrecorreção, o movimento para anterior subsequente dos molares leva a uma verticalização das 
raízes, movimentando as coroas mais para mesial do que as raízes (GIANELLY, 1998).

Os molares distalizados possuem alta tendência de recidivar para mesial, particularmente se os segundos molares estiverem presentes. Essa tendência foi documentada por Andreasen e Naessig (1968) ao notarem que 90\% da distalização do molar produzida pelo AEB foi perdida em uma semana, após a remoção do AEB, sem o uso de qualquer tipo de contenção. O autor recomendou, para a manutenção da posição do molar, o uso de aparelhos de contenção, como, por exemplo, o AEB de uso noturno.

Além disso, os molares não devem ser utilizados como ancoragem por pelo menos 4 a 5 meses após sua distalização, pois a perda de ancoragem pode ocorrer prontamente mesmo com o uso do AEB (GIANELLY, 1998). Isso reflete a natureza instável dos molares imediatamente após a sua distalização. Recomenda-se, por isso, que a mecânica de retração seja iniciada somente 4 a 5 meses pósdistalização. Todavia, isso não se torna uma inconveniência, porque os pré-molares e caninos distalizam-se por si próprios durante esse período de tempo (ARMSTRONG, 1971).

Os terceiros molares superiores irrompidos ou semi-irrompidos tendem a impedir a distalização dos primeiros e segundos molares. Por essa razão, quando possível, indica-se a extração desses dentes (GIANELLY, 1998). Segundo Gianelly (1998), o prognóstico e o índice de sucesso dessa terapêutica dependem da faixa etária apresentada pelos pacientes, que podem então ser divididos em três grupos:

- GRUPO 1: quando os primeiros molares são distalizados na dentadura mista tardia, o procedimento apresenta $90 \%$ ou mais de sucesso. E a correção do molar se dá dentro de 4 a 8 meses.

- GRUPO 2: na adolescência, quando os primeiros molares distalizam após a irrupção dos segundos molares superiores, eles tendem a se mover mais lentamente e a perda de ancoragem aumenta. A relação molar de 1/2 Classe II é corrigida razoavelmente bem. A relação de Classe II completa torna-se mais difícil de resolver. Em muitos momentos, o tratamento alcança o sucesso embora se recomende que haja controle da ancoragem dos incisivos superiores, com o uso de elásticos de Classe II, quando o aumento do trespasse horizontal exceder $2 \mathrm{~mm}$.

- GRUPO 3: no adulto, o sucesso é altamente variável e observam-se muitas dificuldades. 
Deve-se atentar para a grande variação individual observada, indicando que a capacidade de distalizar os molares superiores ainda não permite um prognóstico confiável e totalmente previsível. Sfondrini, Cacciafesta e Sfondrini (2002) realizaram uma revisão das principais técnicas utilizadas para a distalização dos molares superiores e concluíram que, em pacientes Classe I ou suave Classe II esquelética, quando a cooperação for satisfatória, e em casos em que a ancoragem anterior for crítica, a melhor opção de tratamento consiste no emprego do aparelho extrabucal. Se o paciente não cooperar, os aparelhos distalizadores que não requerem a cooperação dos pacientes são indicados, atentando para o controle dos efeitos colaterais. Apenas nos casos de pseudo ou verdadeira Classe III esquelética, com apinhamento no arco dentário superior e relação molar de Classe II, o uso dos distalizadores intrabucais são preferíveis ao aparelho extrabucal, devido à perda de ancoragem anterior ser bem-vinda para o tratamento desses pacientes.

Para a realização do tratamento distalizador, várias formas de tratamento foram idealizadas. Inicialmente, foram sugeridos aparelhos que dependiam da colaboração dos pacientes como os aparelhos extrabucais. Embora o aparelho extrabucal tenha se mostrado efetivo no tratamento da má oclusão de Classe II, para se obter resultados satisfatórios, é fundamental a cooperação do paciente. Portanto, métodos alternativos que não dependam de colaboração dos pacientes têm apresentado maior evidência desde o final da década de 70. Dentre estes dispositivos pode-se destacar o sistema 3D (WILSON, 1978b) e o BDA (WILSON, 1978a), os magnetos (GIANELLY et al., 1988), as molas (MIURA et al., 1988) e os arcos superelásticos (LOCATELLI et al., 1992), o Jones jig (JONES; WHITE, 1992), o Pendulum (HILGERS, 1992), o distal Jet (CARANO; TESTA; SICILIANI, 1996) e o IBMD (KELES; SAYINSU, 2000), entre outros.

\subsection{O aparelho Pendulum e as alterações promovidas}

O aparelho Pendulum foi preconizado por Hilgers (1992) objetivando o tratamento da má oclusão de Classe II com a mínima colaboração do paciente. O aparelho consiste de um botão de resina acrílica localizado no palato, o qual serve como ancoragem, e molas construídas com fio de titânio-molibdênio (TMA) 0.032", as quais se encaixam nos tubos linguais dos molares, exercendo forças moderadas e contínuas, já que o fio TMA permite uma deflexão duas vezes maior que o aço 
inoxidável previamente à deformação permanente (BURSTONE, 1980). As molas são adaptadas ao palato e possuem uma pequena alça horizontal para facilitar os ajustes transversais, um helicóide e uma alça para a retenção no corpo de resina. A denominação do aparelho baseia-se na forma com que as molas agem, como se fosse um pêndulo, partindo da linha média do palato em direção aos molares superiores. A porção anterior do aparelho é estabilizada de várias formas. Originalmente, fez-se por meio de apoios oclusais colados nos molares decíduos ou nos primeiros e segundos pré-molares. Porém Hilgers (1992) afirma que o método mais estável de retenção do aparelho consiste na cimentação de bandas nos primeiros pré-molares ou primeiros molares decíduos e grampos de apoios oclusais nos segundos pré-molares. Essas extensões podem ser removidas, durante 0 tratamento, para permitir o deslocamento natural dos segundos pré-molares para distal. Havendo a necessidade de expansão transversal, adapta-se um parafuso expansor no acrílico da região mediana do palato, transformando-se no aparelho denominado Pend-X, que nada mais é do que uma modificação do aparelho original.

O aparelho Pendulum está indicado para o tratamento da má oclusão de Classe II dentária, isto é, sem comprometimento esquelético significativo, potencial de crescimento craniofacial reduzido e sem uma quantidade expressiva de apinhamento e/ou protrusão no arco inferior (HILGERS, 1992; MACEDO; AIDAR, 2001; RONDEAU, 1995). Pode ainda ser utilizado como recuperador de espaço quando o comprimento do arco superior for deficiente devido à perda precoce dos molares decíduos (MURRELL; LEVIN; KALBFLEISCH, 1996).

A maior contraindicação apontada por Hilgers (1992) diz respeito aos pacientes dolicofaciais, em decorrência da tendência de abertura da mordida anterior promovida pelo uso do aparelho Pendulum. Ursi e Almeida (2002) contraindicam a utilização deste aparelho nos casos de trespasse horizontal aumentado, mordida aberta anterior, ausência de selamento labial, presença de segundos molares irrompidos sem espaço para distalização (presença de terceiros molares) e distância 6-PTV inadequada acompanhada de uma Classe II completa.

Hilgers (1992) afirmou que o aparelho Pendulum proporciona um movimento distal dos molares superiores de $5 \mathrm{~mm}$, num período de 3 a 4 meses. Posteriormente, outros autores como Ghosh e Nanda (1996); Byloff e Darendeliler (1997) realizaram estudos para avaliar os efeitos decorrentes da utilização do aparelho Pendulum e Pend- X respectivamente. No trabalho de Byloff e Darendeliler 
(1997) os autores observaram que o espaço criado deveu-se em $75 \%$ pela distalização dos molares e $25 \%$, pela mesialização dos pré-molares, diferentemente dos dados obtidos por Ghosh e Nanda (1996), em que, de cada $1 \mathrm{~mm}$ de distalização, ocorreu $0,75 \mathrm{~mm}$ de mesialização dos pré-molares; em pacientes Classe II. Os resultados mostraram que a proporção de distalização compreendeu $1,02 \mathrm{~mm} / \mathrm{mês}$, sendo em média de $3,37 \mathrm{~mm}$ a $4,08 \mathrm{~mm}$; o período médio de tratamento consistiu em 4 meses; a perda de ancoragem compreendeu 2,55mm; a presença dos segundos molares superiores não interferiu na distalização obtida; a inclinação distal do primeiro molar superior apresentou-se acentuada em $14,5^{\circ}$ a $8,36^{\circ}$, a inclinação mesial dos primeiros pré-molare s variou de $1,29^{\circ}$ a $7,52^{\circ}$, houve intrusão dos primeiros molares superiores, porém, no estudo de Ghosh e Nanda (1996), essa não foi significativa; ocorreu extrusão dos segundos pré-molares e dos primeiros pré-molares superiores; aumento na distância entre os primeiros molares superiores e, entre os segundos molares; protrusão do lábio superior e inferior; aumento do trespasse horizontal; redução do trespasse vertical e vestibularização dos incisivos superiores.

No estudo realizado por Ghosh e Nanda (1996), os autores observaram efeitos esqueléticos promovidos pelo aparelho Pendulum, sendo que o maior deles ocorreu na AFAl, que aumentou 2,79mm em média e 2 vezes mais em pacientes que apresentavam FMA $>24^{\circ}$. O plano mandibular incl inou inferiormente em média $1,09^{\circ}$, proporcionando a redução do trespasse vertic al $(1,39 \mathrm{~mm})$. Os resultados mostraram que o aparelho Pendulum afeta primariamente os dentes e o osso alveolar, embora possua efeitos indiretos nas estruturas esqueléticas e tecidos moles. Contrariamente, Byloff e Darendeliler (1997) não determinaram qualquer efeito esquelético ocasionado pelo aparelho sem a ocorrência de mordida aberta dentária ou esquelética.

As alterações dentoalveolares e esqueléticas promovidas pelo aparelho Pendulum em pacientes que apresentavam má oclusão de Classe II foram analisadas por alguns autores (BUSSICK; MCNAMARA, 2000). Bussick e McNamara Jr (2000) analisaram a quantidade e a natureza da distalização dos molares superiores e o efeito na ancoragem anterior (pré-molares e incisivos), assim como as alterações esqueléticas sagitais e verticais das dimensões da face. A amostra foi composta por 101 pacientes (56 do gênero feminino e 45, do masculino) com idade inicial média de 12 anos, sendo o tempo total de tratamento de 7 meses. 
As molas foram ativadas $60^{\circ}$ a 90ㅜ, produzindo uma força de 200 a 250 gramas. Para avaliar o efeito do tratamento em relação ao estágio de desenvolvimento dentário, a amostra foi dividida em subgrupos: de acordo com a presença $(n=33)$ e, ausência $(n=68)$ dos segundos molares decíduos e, de acordo com o grau de erupção dos segundos molares permanentes irrompidos $(n=44)$ e, não irrompidos $(n=57)$. Além disso, o estudo analisou a resposta do aparelho frente aos diversos padrões faciais indicados pelo ângulo do plano mandibular (FMA), havendo 30 pacientes com ângulo baixo (FMA < que 21ํ), 38, com ângulo neutro (FMA entre 21ำ e 26) e, 33, com ângulo alto (FMA > 269. Os resul tados indicaram que o aparelho Pendulum atuou principalmente no arco dentário superior, promovendo, entretanto, efeitos de pequena significância sobre as estruturas esqueléticas e os tecidos moles. Os primeiros molares superiores distalizaram em média 5,7mm, com uma inclinação distal de 10,6ํㅡ e os dentes de ancoragem anterior sofreram mesialização de 1,8mm, sendo que os pré-molares apresentaram inclinação mesial de $1,5^{\circ}$ e os incisivos, uma inclinação para vestibular. Desse modo, a distalização dos molares contribuiu em $76 \%$ do total do espaço obtido enquanto $24 \%$ deveram-se a perda de ancoragem dos pré-molares, sendo que, para cada $1 \mathrm{~mm}$ de distalização, houve $0,32 \mathrm{~mm}$ de perda de ancoragem.

Com relação à movimentação vertical, observou-se que os molares permanentes intuíram $0,7 \mathrm{~mm}$ e os pré-molares extruíram $1,0 \mathrm{~mm}$, enquanto os molares inferiores mesializaram $0,2 \mathrm{~mm}$ e extruíram $0,7 \mathrm{~mm}$ sem significância estatística. O trespasse vertical diminuiu $1,7 \mathrm{~mm}$, e o horizontal aumentou $0,8 \mathrm{~mm}$. 0 lábio superior e inferior protruíram 0,6mm, e 1,0mm, respectivamente. As alterações verticais ocorreram em menor magnitude, apresentando o ângulo do plano oclusal, do plano mandibular e a AFAI um suave aumento durante o tratamento. Nenhuma diferença na quantidade de distalização foi observada com relação à presença ou não dos segundos molares irrompidos havendo, entretanto, uma influência nas alterações verticais, sendo que o grupo que possuía os segundos molares irrompidos apresentou um significante aumento na AFAl e no FMA. Com relação ao padrão de crescimento facial, não houve diferença entre os grupos analisados (FMA alto, neutro e baixo). A distalização indicou uma maior extrusão dos molares e um maior aumento da AFAl em relação à distalização na dentadura mista. Os autores concluíram que o aparelho Pendulum deve ser utilizado apenas em pacientes que realmente iriam se beneficiar pela distalização dos molares, e, para se obter a 
máxima distalização e o mínimo aumento na AFAl, o aparelho deveria ser instalado em pacientes que apresentassem os segundos molares decíduos e ausência dos segundos molares permanentes irrompidos, embora não tenha sido constatada nenhuma abertura significante da mordida.

Fuziy (2001) desenvolveu uma pesquisa para avaliar as alterações sagitais, verticais e transversais decorrentes da utilização do aparelho Pendulum para distalizar os primeiros molares superiores. A amostra foi composta por 32 pacientes (23 do gênero feminino e 9, do masculino) com má oclusão de Classe II, divisão 1 e idade inicial média de 14 anos e 10 meses. Foram analisadas as telerradiografias em norma lateral e em 45ㅜ, além dos modelos iniciais e após a distalização promovida pelo aparelho Pendulum, sendo o período médio de tratamento foi 5,85 meses. $O$ autor utilizou dobras de anti-inclinação para controlar a posição dos molares superiores, além de realizar uma sobrecorreção. A contenção foi realizada com o Botão de Nance. Com base nos resultados obtidos e na metodologia utilizada, pode-se concluir que a força suave e continua impulsionada pelas molas de TMA não promoveu alterações esqueléticas significantes na maxila e mandíbula. Os primeiros e segundos molares superiores distalizaram em média $4,83 \mathrm{~mm}$ e $4,84 \mathrm{~mm}$, respectivamente, sendo que a inclinação para distal foi $12,66^{\circ}$ e $16,23^{\circ}$ respectivamente. $O$ efeito do aparelho sobre a unidade de ancoragem promoveu uma mesialização dos primeiros pré-molares de $1,87 \mathrm{~mm}$ com inclinação para mesial de $2,51^{\circ}$, e dos incisivos centrais, de $1,08 \mathrm{~mm}$, e in clinação vestibular, de $3,40^{\circ}$. Os molares distalizaram em média $1,06 \mathrm{~mm}$ por mês, sendo que a abertura do espaço ocorreu devido a $78,72 \%$ de distalização dos molares e $30,72 \%$ de mesialização dos pré-molares. Com relação à movimentação vertical dos dentes, os segundos molares apresentaram uma intrusão de $0,78 \mathrm{~mm}$ e os primeiros pré-molares superiores, uma extrusão de $1,52 \mathrm{~mm}$. O trespasse horizontal aumentou $1,56 \mathrm{~mm}$ e o vertical reduziu $1,03 \mathrm{~mm}$. Devido a essas alterações dentárias, houve uma rotação do plano mandibular no sentido horário, refletindo em um aumento significante da AFAl de $1,94 \mathrm{~mm}$. As alterações transversais foram comprovadas pelo aumento de $0,71 \mathrm{~mm}$ na região dos molares e $0,12 \mathrm{~mm}$ na região dos primeiros pré-molares. Devido ao aumento do trespasse horizontal, o ângulo nasolabial apresentou um aumento de $1,35^{\circ} \mathrm{e}$ o lábio superior, uma protrusão de $0,29 \mathrm{~mm}$.

Toroglu et al. (2001) avaliaram os efeitos do aparelho Pendulum em pacientes com má oclusão de Classe II, considerando o padrão de crescimento facial (FMA) e 
as alterações após 3 meses de contenção. A amostra constituiu-se de 30 pacientes (18 do gênero feminino e 12, do masculino) divididos em dois grupos: grupos 1, composto por 16 pacientes com ângulo do plano mandibular baixo (FMA menor ou igual a 249 e grupo 2, com 14 pacientes com ângulo do plano mandibular alto (FMA maior ou igual a 299. Analisaram-se as telerradiog rafias iniciais, finais e após 3 meses de contenção. O tempo médio de tratamento para o grupo 1 foi de 5,03 meses e 5,7 meses, para o grupo 2, porém sem diferença significante. $O$ grupo 2 (FMA alto) apresentou uma maior quantidade de distalização $(5,9 \mathrm{~mm})$ e de inclinação para distal do que o grupo com FMA baixo $(1 \mathrm{~mm})$. Na análise da unidade de ancoragem, o grupo 1 (FMA baixo) indicou maior quantidade de mesialização do que 0 grupo 2, sendo que os pré-molares mesializaram $6,6 \mathrm{~mm}$ e $4,8 \mathrm{~mm}$, respectivamente, e os incisivos $4,1 \mathrm{~mm}$ no grupo 1 e 2,1 $\mathrm{mm}$ no grupo 2. Desse modo, os autores relataram que quanto maior a resistência a distalização maior seria a perda de ancoragem. Os incisivos do grupo 2 (FMA alto) apresentaram uma maior quantidade de extrusão. $O$ trespasse horizontal e o grau de protrusão do lábio superior e inferior aumentaram nos dois grupos devido à vestibularização dos incisivos superiores. Durante o período de contenção, observou-se que houve uma perda de ancoragem na região dos molares de $1,5 \mathrm{~mm}$ para o grupo 2 (FMA alto) e $1,7 \mathrm{~mm}$ para o grupo 1 (FMA baixo) e os incisivos e pré-molares revelaram uma recidiva aos seus lugares iniciais. Desse modo, o resultado deste estudo permitiu concluir que o Pendulum promoveu a distalização dos molares superiores sem a cooperação do paciente, havendo, porém a necessidade de uma boa contenção pós-distalização a qual poderia ser realizada com o Botão de Nance e o uso noturno da ancoragem extrabucal, além da realização de uma sobrecorreção da relação molar.

Chaques-Asensi e Kalra (2001) desenvolveram um estudo para determinar os efeitos promovidos pelo aparelho Pendulum. Para isso, analisaram 26 pacientes (10 do gênero masculino e 16 do feminino) com idade inicial média de 11 anos e 2 meses, sendo o tempo médio de tratamento 6,5 meses ( 0,8 mês). A análise dos resultados mostrou que os molares superiores distalizaram $5,3 \mathrm{~mm}$, inclinaram para distal $13,1^{\circ} \mathrm{e}$ intruíram $1,2 \mathrm{~mm}$. Os primeiros pré-mo lares superiores ou primeiros molares decíduos mesializaram 2,2 $\mathrm{mm}$, inclinaram para mesial 4,8 ${ }^{\circ}$ e extruíram 1,2 $\mathrm{mm}$ e os incisivos centrais superiores protruíram $2,1 \mathrm{~mm}$ e inclinaram para vestibular $5,1^{\circ}$. O trespasse horizontal aumentou $1,8 \mathrm{~mm}$ e o ve rtical diminuiu $1,8 \mathrm{~mm}$. A altura 
facial anteroinferior aumentou $2,8 \mathrm{~mm}$, enquanto que o FMA aumentou $1,3^{\circ}$, tendo por isso, os autores contraindicado o uso em pacientes que apresentassem AFAI aumentada ao início do tratamento e/ou mordida aberta.

Kinzinger et al. (2005) verificaram a qualidade da ancoragem dentária anterior durante o uso do aparelho Pendulum modificado para determinar a época mais favorável dessa medida terapêutica em relação ao estágio da dentição. A amostra foi composta por 30 pacientes (14 do gênero feminino e 16, do masculino) com idade inicial média de 11 anos e 5 meses. 0 tempo médio de tratamento foi de 22 semanas (5,5 meses). Todos os pacientes apresentavam os primeiros molares completamente irrompidos e os segundos e terceiros não irrompidos e foram divididos em 3 grupos de 10 pacientes cada um, de acordo com os dentes utilizados como ancoragem anterior. $\mathrm{O}$ grupo 1 apresentava os primeiros e segundos molares decíduos, o grupo 2 utilizou os primeiros pré-molares e segundos molares decíduos e o grupo 3 , apenas os pré-molares. Os resultados deste estudo demonstraram que os molares decíduos e pré-molares poderiam ser utilizados como ancoragem do aparelho Pendulum, entretanto, a quantidade de distalização foi maior, a inclinação para distal menos pronunciada e menor efeito na unidade de ancoragem quando se utilizou apenas o pré-molar como ancoragem. Desse modo, quando se utilizam os pré-molares e molares decíduos como ancoragem, obtêm-se mais efeitos indesejáveis, como maior inclinação dos molares para distal e maior protrusão dos incisivos.

Devido à escassez de trabalhos na literatura que avaliavam os efeitos do tratamento com aparelho Pendulum seguido de aparelhagem ortodôntica fixa, Angelieri et al. (2006) analisaram as telerradiografias iniciais, após a distalização dos molares superiores, após o alinhamento e nivelamento dentários e na finalização do tratamento ortodôntico fixo. A amostra foi composta por 22 pacientes (15 do gênero feminino e 7, do masculino) com idade inicial média de 14,5 anos. $O$ tempo médio de distalização dos molares compreendeu 5,85 meses e o tempo total de tratamento, 3,61 anos. Os resultados deste estudo demonstraram que o aparelho Pendulum promoveu uma distalização dos molares superiores, com inclinação para distal, protrusão do dentes anteriores e aumento da AFAl devido à rotação no sentido horário da mandíbula. No período pós-distalização houve uma mesialização dos primeiros molares $(2,1 \mathrm{~mm})$ mesmo havendo realizado o reforço de ancoragem (Botão de Nance e ancoragem extrabucal cervical com uso somente a noite). 
Terminado o tratamento ortodôntico fixo, os incisivos, pré-molares e primeiros molares mostravam-se no mesmo posicionamento inicial, apesar de todos os pacientes terem apresentado relação molar de Classe I ao final do tratamento. Dessa maneira, pode-se concluir que a mecânica empregada corrigiu a má oclusão de Classe II devido às alterações dentoalveolares promovidas (não houve efeitos esqueléticos significantes) e, secundariamente, ao crescimento mandibular para anterior, constatado durante a utilização do aparelho ortodôntico fixo.

Angelieri et al. (2008), comparou os efeitos cefalométricos promovidos pelo aparelho extrabucal cervical e o aparelho Pendulum, associados ao aparelho ortodôntico fixo. A amostra inicial foi dividia em 2 grupos. O grupo 1 composto por 30 pacientes tratados por meio do aparelho extrabucal cervical associado ao aparelho ortodôntico fixo por um período médio de 3,28 anos e grupo 2, composto por 22 pacientes, tratados com o aparelho Pendulum seguido do aparelho ortodôntico fixo por um tempo médio de 4,12 anos. Foram avaliadas telerradiografias em norma lateral ao início e ao final do tratamento ortodôntico. Os grupos Pendulum e AEB foram compatibilizados em relação a idade inicial, gênero da amostra, severidade da má oclusão de Classe II, características cefalométricas iniciais e índice de prioridade de tratamento (IPT) inicial e final. Apenas o tempo de tratamento mostrou-se incompatível entre os grupos, havendo a necessidade da anualização dos dados referentes ao grupo Pendulum. O grupo AEB apresentou redirecionamento do crescimento maxilar, resultando na restrição do vetor de crescimento maxilar para anterior e melhora da relação maxilomandibular. No grupo Pendulum, verificaram-se somente efeitos dentoalveolares, ocorrendo, além disso, um aumento da altura facial posterior no grupo $A E B$, em decorrência da maior extrusão dos primeiros molares superiores. Por outro lado, esta maior extrusão dos primeiros molares superiores não resultou em uma rotação horária da mandibula. Ambos os aparelhos corrigiram a má oclusão de Classe II de forma semelhante, com a estabilização do complexo dentoalveolar superior, proporcionado pelos aparelhos distalizadores, enquanto que o complexo dentoalveolar inferior avançou em direção anterior, devido ao crescimento mandibular. Não houve diferença nas repercussões de ambos os tratamentos no perfil facial tegumentar. O uso mais acentuado dos elásticos de Classe II no grupo Pendulum resultou em uma maior inclinação para vestibular/mesial dos incisivos e molares inferiores. 
Em 2009, Pinzan-Vercelino et al. desenvolveram um estudo com o propósito de comparar os graus de eficiência do tratamento da má oclusão de Classe II, realizado com o aparelho Pendulum e com extrações de dois pré-molares superiores. A amostra constituiu-se dos modelos de gesso e das telerradiografias de 48 pacientes com má oclusão de Classe II, divididos em dois grupos de acordo com o protocolo de tratamento, sendo que ambos os grupos utilizaram o aparelho fixo. $O$ grupo 1, composto por 22 pacientes (7 do gênero masculino e 15, do feminino) foi tratado com o aparelho Pendulum e o grupo 2, constituído de 26 pacientes (14 do gênero masculino e 12, do feminino) tratado com extrações de dois pré-molares superiores. Para a comparação entre os graus de eficiência, os resultados oclusais foram avaliados em modelos de gesso por meio do índice oclusal PAR, enquanto que o tempo de tratamento de cada grupo foi calculado a partir das anotações clínicas presentes nos prontuários. Os resultados demonstraram que o grupo 2 apresentou um maior grau de eficiência do que o grupo 1, com um tempo de tratamento significantemente menor.

Almeida-Pedrin et al. (2009) realizaram um estudo retrospectivo, onde compararam os efeitos cefalométricos, as alterações no arco dentário e a eficiência do tratamento da Classe II com o aparelho Pendulum, extrabucal cervical, ou extração de dois pré-molares superiores todos associados ao aparelho ortodôntico fixo. A amostra foi composta modelos de gesso e telerradiografias de 82 pacientes com má oclusão de Classe II, divididos em três grupos. No grupo 1 ( $n=22$, tempo de tratamento, 3,8 anos) os pacientes foram tratados com o aparelho Pendulum, no grupo 2 ( $n=30$, tempo de tratamento 3,2 anos) os pacientes utilizaram aparelho extrabucal cervical, já no grupo 3 ( $n=30$, tempo de tratamento 2,1 anos) foram tratados a partir da extração de dois pré-molares superiores. Os resultados apontaram que os três protocolos de tratamento produziram efeitos cefalométricos similares. $\mathrm{O}$ índice de prioridade de tratamento demonstrou que resultados oclusais também foram semelhantes entre os grupos enquanto que índice de eficiência do tratamento apresentou valores maiores para o grupo de extração. Concluindo que os protocolos de tratamento comparados foram similares do ponto de vista oclusal e cefalométrico. O tratamento da má oclusão de Classe II através da extração de dois pré-molares superiores foi mais eficiente devido ao menor tempo de tratamento.

Kinzinger et al. (2010) realizaram um estudo com o objetivo de avaliar os efeitos da ancoragem convencional no desenvolvimento das raízes dos pré-molares 
durante $\circ$ tratamento com $\circ$ Pendulum. Os molares superiores foram distalizados com o aparelho Pendulum modificado (Pendulum K) em 36 pacientes (14 do gênero masculino e 22, do feminino) com idade média de 12,3 anos. Foram tomadas duas radiografias panorâmicas de cada paciente, uma inicial e outra após a distalização do molar. Posteriormente, foi medido por vestibular o comprimento dos pré-molares cuja raiz ainda não estava completamente desenvolvida. Para avaliar o desenvolvimento radicular foi calculada a diferença entre o comprimento dos dentes, no início e final do tratamento. Durante o tratamento foi observado um aumento no comprimento do dente na região de ancoragem. A biomecânica do Pendulum $\mathrm{K}$ permite que a transferência das forças para as unidades de ancoragem permaneçam dentro de limites fisiológicos, possibilitando o desenvolvimento normal das raízes dos pré-molares.

\subsubsection{Contenção após a distalização}

A mesialização dos molares durante a terapia ortodôntica fixa que se segue a fase de distalização foi observada por Burkhardt, McNamara e Baccetti (2003). Os autores verificaram uma recidiva da distalização dos molares de $87 \%$ em relação à primeira fase do tratamento (uso do Pendulum), embora a relação molar normal tenha sido mantida e o trespasse horizontal, corrigido. De acordo com os autores, a manutenção da relação molar e da correção do trespasse horizontal, mesmo com a recidiva da distalização, pode ser explicada por um padrão de crescimento favorável e compensações dentoalveolares.

Para estabilização dos molares distalizados, Hilgers (1992) propôs: 1) Instalação do aparelho ortodôntico fixo conjuntamente a um arco-utilidade superior que contém os molares em suas posições utilizando os incisivos superiores como ancoragem. Os pré-molares são retraídos com o uso de cadeias elastoméricas. 2) Inserção de um Botão de Nance confeccionado durante a consulta de remoção do aparelho Pendulum. De acordo com o autor, essa consiste na forma mais estável e confiável de contenção dos molares superiores. 3) Instalação do aparelho ortodôntico fixo associado a um arco com Omega por mesial ao primeiro molar superior. Recomendou ainda a associação de um Botão de Nance. 4) Uso do AEB por poucos meses até a distalização completa dos pré-molares e caninos. Embora requerida a colaboração do paciente, essa compreende um curto período de tempo. 
Posteriormente, Rondeau (1995) revisando a literatura, sugeriu outros meios de contenção. $O$ aparelho Pendulum pode ser modificado em um aparelho de contenção pelo corte da extensão da porção de resina acrílica ao primeiro pré-molar e pela desativação das molas TMA. Outra forma compreende a combinação da barra transpalatina ao Botão de Nance, proporcionando ancoragem adequada para a retração dos pré-molares e caninos, ou mesmo a utilização do aparelho RickANator, que consiste em um Botão de Nance modificado, em que a região anterior de acrílico constitui-se em um plano de mordida anterior, desocluindo os dentes posteriores. E indicado nos casos nos quais ha sobremordida profunda e os incisivos apresentam-se lingualizados.

Mesmo após a aparelhagem fixa, os molares distalizados possuem alta tendência de recidivar para mesial, particularmente se os segundos molares estiverem presentes. Essa tendência foi documentada por Andreasen e Naessig (1968) os autores notaram que $90 \%$ da distalização do molar, produzida pelo AEB, foi perdida uma semana após a remoção do AEB, sem o uso de qualquer tipo de contenção, portanto recomendaram, para a manutenção da posição do molar, o uso de aparelhos de contenção, como, por exemplo, o AEB de uso noturno. A maioria dos trabalhos que avaliaram os efeitos do aparelho Pendulum, recomendam a sobrecorreção dos molares em uma super Classe I devido a tendência a recidiva, visto que se observa uma inclinação dos molares distalizados (ANGELIERI et al., 2006; BURKHARDT; MCNAMARA; BACCETTI, 2003; BYLOFF; DARENDELILER, 1997; BYLOFF et al., 1997; CHAQUES-ASENSI; KALRA, 2001; GHOSH; NANDA, 1996; HILGERS, 1992; URSI; ALMEIDA, 2002).

\subsection{Estabilidade do tratamento da má oclusão de Classe II:}

Sabendo da importância do correto posicionamento mesiodistal dos longos eixos dentários para a manutenção da estabilidade dos resultados obtidos pelo tratamento ortodôntico, Holdaway (1952) sugeriu a incorporação de angulações nos braquetes substituindo as dobras de segunda ordem nos fios de nivelamento. Segundo o autor, os braquetes devem ser angulados para compensar a folga do fio ortodôntico dentro de suas canaletas nos dentes submetidos a maiores movimentações. Este artifício também pode ser empregado no preparo de ancoragem e na substituição das dobras artísticas, resultando numa inclinação mais 
divergente dos longos eixos dentários, e proporcionando uma anatomia mais natural, principalmente no segmento anterossuperior do arco dentário. $\mathrm{O}$ autor alertou ainda que muitos casos eram concluídos sem a obtenção do paralelismo radicular. Nos locais das extrações, as raízes dos dentes adjacentes apresentavam uma configuração em "V", sendo este um dos fatores predisponentes à reabertura de espaço.

Young (1964) observou que cada dente encontra-se posicionado conforme o tipo de esforço requisitado, sendo que as suas distintas inclinações correspondem a um modelo perfeito de estabilidade sob função. A inclinação para distal de seus ápices possibilita a oclusão de dois dentes antagonistas numa posição bastante vantajosa, permitindo que a força oclusal seja transmitida paralelamente às suas raízes. Quando isto não ocorre, observa-se danos aos tecidos de sustentação e aos dentes.

Segundo Wheeler (1965), normalmente os dentes apresentam suas coroas inclinadas para mesial em graus variáveis e embora diferentes crânios apresentem discrepâncias quanto aos valores absolutos, geralmente observa-se uma tendência a essa inclinação mesial. $O$ autor afirmou que cada dente apresenta a inclinação que melhor resiste às forças mastigatórias e se algum dente encontrar-se mal posicionado, sua eficiência funcional torna-se prejudicada, assim como, sua estabilidade. Esta disposição espacial específica garante a manutenção dos pontos de contato proximais dentários e a correta dissipação das forças funcionais.

Considerando-se que o paciente que possui uma má oclusão de Classe II, divisão 1, pode, geralmente, apresentar uma associação de alterações dentárias, musculares, ósseas e nervosas, torna-se necessário o restabelecimento da harmonia entre todos esses sistemas para se obter estabilidade dos resultados do tratamento.

Uhde, Sadowsky e BeGole (1983) buscaram determinar se as alterações póstratamento (mínimo de 12 anos) das relações dentárias estão relacionadas a Classe de Angle da má oclusão original, dentre outras coisas. Estudaram 72 casos com más oclusões de Classe I ou II, com idade média de 20 anos, tratados com e sem extrações. Como resultados, observaram que a alteração pós-tratamento da relação molar era sempre em direção a Classe II. A medida que a relação molar se alterou em direção ao valor original após o tratamento, a distância intermolares superiores diminuiu e o overjet aumentou, ambos em direção aos valores originais. Concluíram 
que, apesar das relações anterossuperiores dos molares tenderam a se alterar em direção a Classe II após o tratamento, elas foram relativamente estáveis em ambos os casos de Classe I e Classe II e não relacionadas com a presença ou não de extrações.

Nashed e Reynolds (1989) avaliaram cefalometricamente 50 casos com má oclusão de Classe II, divisão 1, tratados ortodonticamente, visando analisar os dados resultantes das características craniofaciais que poderiam prever o sucesso na redução do overjet durante e após o tratamento. Os pacientes apresentavam, ao início do tratamento, um overjet entre 10 a $15 \mathrm{~mm}$. Os autores não encontraram fortes predictores para a redução e estabilidade do overjet. Observaram também que quanto maior a redução do overjet com o tratamento, maior a probabilidade de o mesmo apresentar uma recidiva.

Weiland (1994) realizou um estudo que tinha por finalidade verificar a influência das discrepâncias oclusais na estabilidade em longo prazo do tratamento ortodôntico. Os modelos de estudo e os registros cefalométricos de 40 pacientes (9 Classe I, 24 Classe II, divisão 1 e 7 Classe II, divisão 2) foram avaliados antes do início do tratamento, ao final e pelo menos 9 anos após a remoção da contenção. Como resultado, encontrou que a largura e o comprimento do arco diminuíram significativamente após a contenção. A posição dos incisivos inferiores permaneceu relativamente estável, enquanto a dos molares inferiores se moveu substancialmente para frente. A irregularidade anteroinferior aumentou após o tratamento, e 60\% dos casos apresentaram um alinhamento insatisfatório. A quantidade de deslize mandibular diminuiu com o tempo e teve uma influência estatisticamente significante, embora clinicamente apenas moderada no aumento da irregularidade anteroinferior, ou seja, contribuiu com apenas $15 \%$ da variação na irregularidade. Os molares inferiores, que se moveram para frente durante e após o tratamento, foram responsáveis pela diminuição do comprimento do arco. Os autores afirmaram que, para melhorar a estabilidade, deve-se manter a menor distância possível entre a relação crítica e a máxima intercuspidação habitual, e ótimas relações oclusais devem ser obtidas ao final do tratamento.

Já Binda et al. (1994) analisaram as alterações pós-contenção de variáveis esqueléticas, dentárias e de tecido mole na má oclusão de Classe II, divisão 2, independentemente do tipo de tratamento. Os pacientes foram avaliados ao início e ao final do tratamento, e 2 e 5 anos pós-contenção. Observavam que muitas das 
alterações que ocorreram nesses períodos foram consequentes ao crescimento mandibular natural e as adaptações das alterações induzidas pelo tratamento e que todas as medidas apresentaram alterações significantes, principalmente nos dois primeiros anos após o término do tratamento. A recidiva da sobremordida encontrase relacionada à recidiva da inclinação dos incisivos superiores que ocorre nesse tipo de má oclusão. As alterações com o tempo foram maiores para os pacientes do gênero masculino do que para o feminino, sendo também, menores para os grupos com idades mais avançadas. Durante o tratamento, o ângulo interincisivos e o overbite diminuíram, e, na fase pós-contenção, ambos aumentaram significantemente. Os autores não avaliaram a estabilidade da relação molar.

No mesmo ano Bishara et al. (1994) estudaram pacientes com má oclusão de Classe II, divisão 1, com abordagem sem extrações de pré-molares, e com extrações de quatro primeiros pré-molares, tratados com a técnica do Arco de Canto, sendo que o resultado final desses tratamentos foi considerado sucesso. Uma série de parâmetros foi medida em modelos de gesso, antes, durante e pelo menos 2 anos após o final do tratamento. Como resultados, observaram que, no estágio pós-tratamento, os dois grupos experimentaram um aumento similar na discrepância entre o tamanho dentário e o comprimento do arco.

Harris et al. (1994) avaliaram duas amostras de casos com má oclusão de Classe II, divisão 1, todos tratados por um único especialista, examinados dentro de uma média de 5 anos após o tratamento. Um grupo tinha sido tratado durante a adolescência (aproximadamente 12 anos de idade), o outro, na idade adulta (aproximadamente 28 anos). Observou-se que dois tipos de alterações ocorreram na mesma extensão em ambos os grupos e indicaram previsibilidade independentemente da idade: o primeiro molar superior sofre leve inclinação anterior da coroa e movimento mesial de corpo; a correção molar total voltou-se ligeiramente para relação de Classe II por volta de $1 \mathrm{~mm}$. Essa alteração foi estatisticamente equivalente nos dois grupos. O primeiro molar superior migrou para mesial bem mais nos pacientes adolescentes que nos adultos. Isso não afetou a correção molar total, visto que o molar inferior também foi para frente pelo crescimento diferencial da mandíbula, sendo este maior nos adolescentes do que nos adultos. Houve um crescimento apreciável para frente tanto da maxila quanto da mandíbula nos adolescentes, mas não nos adultos. Nestes, a maior alteração ficou por conta do movimento desfavorável, tanto de corpo como de inclinação para mesial do molar 
superior, que, mesmo assim, ficou mais estável nos adolescentes. Portanto, as correções ortodônticas foram estáveis em ambos os grupos, mas por motivos diferentes.

Um ano depois Fidler et al. (1995) examinaram a estabilidade em longo prazo da má oclusão de Classe II, divisão 1, de Angle, com resultados oclusais satisfatórios ao final do tratamento ativo, procurando por predictores da recidiva e por características associadas com um tratamento de sucesso. A amostra consistiu de 78 pacientes Classe II, divisão 1, tratados com ou sem extrações dentárias, por um período médio de 14 anos pós-contenção. Os resultados demonstraram não ter havido nenhuma alteração pós-contenção para as relações dos molares, prémolares e caninos e uma recidiva de $0,5 \mathrm{~mm}$ para o overjet e o overbite. A recidiva máxima foi de 3,5 $\mathrm{mm}$ para a relação molar, pré-molar e canino, $3 \mathrm{~mm}$ para o overjet e 4,5 mm para o overbite. A análise de regressão múltipla revelou não existir associação alguma entre as características do tratamento nem entre as alterações esqueléticas e dentárias do tratamento e a recidiva do overjet. Entretanto, a recidiva do overjet associou-se a recidiva das relações molar, pré-molar e canino, ao aumento pós-contenção no overbite, a pró-inclinação pós-contenção dos incisivos superiores e a verticalização pós-contenção dos incisivos inferiores. As alterações do tratamento ativo incluíram um redirecionamento e uma inibição do crescimento maxilar e uma retração dos incisivos superiores. O crescimento mandibular adicional foi favorável durante e após o tratamento. Concluiu-se que a correção satisfatória da má oclusão de Classe II, divisão 1 de Angle por meio da adaptação do crescimento diferencial e de movimentos dentários parece ser bem estável.

Otuyemi e Jones (1995) utilizaram o índice PAR para avaliar o tratamento e os resultados pós-contenção em longo prazo de 50 casos de má oclusão de Classe II, divisão 1. Foram empregados os modelos de estudo para registro da oclusão pré, pós-tratamento, 1 ano pós-tratamento e 10 anos pós-tratamento, estando esta última avaliação sem contenções. Os resultados sugeriram um tratamento ortodôntico de alto padrão, indicado pela porcentagem média de redução do índice PAR. Entretanto, a manutenção dos resultados pós-tratamento após 1 e 10 anos póscontenção apenas foi alcançada em 60 e 38\% dos casos, respectivamente. 0 principal fator envolvido nessa deterioração foi relatado como sendo o apinhamento anteroinferior. Concluíram que, apesar de uma má oclusão de Classe II tratada com 
sucesso aparentemente apresentar uma tendência a deteriorar após o tratamento, muito desse resultado é o retorno do apinhamento anteroinferior.

Elms, Buschang e Alexander (1996) avaliaram em modelos de gesso a estabilidade do tratamento da má oclusão de Classe II desenvolvido em 42 pacientes com o aparelho fixo associado ao extrabucal e que apresentaram bons resultados ao término do mesmo. Foi observado um aumento de 0,5 mm no trespasse horizontal e de 0,4 $\mathrm{mm}$ no trespasse vertical. $O$ índice de irregularidade dos incisivos inferiores aumentou apenas $0,4 \mathrm{~mm}$ depois do tratamento. Os autores concluíram que as ações com vistas a solução da má oclusão de Classe II sem extração mostraram-se altamente estáveis. Logo após, os próprios autores, publicaram a avaliação cefalometrica dos mesmos pacientes citados na pesquisa anterior. Os resultados demonstraram que o ângulo ANB diminuiu $2^{\circ}$ durante 0 tratamento, devendo-se isso, possivelmente, a diminuição do ângulo SNA, que foi de $1,6^{\circ}$. O molar inferior inclinou-se $4^{\circ}$ para trás. El es afirmaram que, de acordo com seus resultados, a cada $3^{\circ}$ de inclinação do molar p ara trás, haverá cerca de $1^{\circ} \mathrm{de}$ recidiva dessa inclinação.

A estabilidade de diferentes aparelhos foi comparada por Omblus et al. (1997) que avaliaram os efeitos esqueléticos e dentários em longo prazo do tratamento com os aparelhos Herbst e Bass. Avaliaram os casos ao início do tratamento, após 6 meses da remoção dos aparelhos e após o final do crescimento. Seis meses após a remoção dos aparelhos, o tratamento com o Bass pareceu ter um efeito maior na posição da mandíbula. A correção do overjet e da relação molar foi mais completa com o Herbst devido às alterações dentárias. De um modo geral, as alterações esqueléticas e dentárias do início ao final do crescimento foram de mesma magnitude para os 2 aparelhos avaliados. Ambos os tratamentos foram efetivos na correção das más oclusões de Classe II severas. Como se pode observar, após a revisão de literatura sobre a estabilidade da correção da má oclusão de Classe II, os estudos são, em sua maioria, direcionados a um determinado tipo de aparelho ou protocolo de tratamento, ou uma comparação dos mesmos. Cefalogramas laterais e modelos de estudo de 55 pacientes foram avaliados por Lenz e Woods (1999) a fim de determinar a existência de relação entre as posições e angulações dos incisivos, como também entre as suas alterações e a estabilidade oclusal em longo prazo. Nenhuma relação significante pode ser encontrada entre as alterações em longo prazo que ocorrem num número de 
medidas incisais comumente utilizadas e as posições dos incisivos durante 0 tratamento, ou alterações em longo prazo no ângulo do eixo facial, ângulo ANB, ou o índice PAR. As alterações nos incisivos que aconteceram em longo prazo nos pacientes individualmente não estavam necessariamente associadas com alterações oclusais negativas. Considerando que as posições dos incisivos sempre se alteram em longo prazo, sugere-se que a utilização de normas recomendadas para as posições dos incisivos ao final do tratamento sejam empregadas mais como um guia clinico funcional geral e estético, em vez de fator de previsão da estabilidade.

Yavari et al. (2000) examinaram uma amostra de pacientes com Classe II, divisão 1 , com um overjet de no mínimo $3 \mathrm{~mm}$, cujo tratamento se deu sem a realização de extrações, nas fases pré, pós-tratamento e pós-contenção (pelo menos 2 anos), e encontraram relativa estabilidade de todas as variáveis analisadas: trespasses vertical e horizontal, apinhamento anteroinferior, posição do incisivo inferior, distâncias intermolares e intercaninos. Relataram também a discrepância de seus resultados com os da literatura, mostrando a necessidade de reavaliação da filosofia de tratamento e da estabilidade em longo prazo. Segundo os autores, a diferença em suas conclusões pode estar relacionada à mecânica utilizada, visando a preservação da forma do arco, a extração dos terceiros molares, e ao fato de que todos os pacientes da amostra foram tratados por apenas um especialista.

Woods, Lee e Crawford (2000) executaram um estudo com modelos de estudo de 65 pacientes nos estágios pré, pós-tratamento e pelo menos 6,5 anos após a remoção de todos os aparelhos de contenção. Não especificaram o tipo de má oclusão dos pacientes. O método de avaliação da oclusão foi o índice PAR, calculado nos modelos de cada paciente, nos três estágios avaliados. Calculou-se a média do índice PAR da amostra total e posteriormente para cada subgrupo, além da porcentagem média de alteração do índice PAR entre as fases estudadas. $O$ índice PAR sofreu uma redução de $85,6 \%$ com o tratamento e teve um aumento de $15,2 \%$ no período pós-contenção. Os autores afirmaram que nem todas as alterações oclusais são negativas e, em alguns casos, e mesmo possível que ocorra uma considerável melhora oclusal durante ou após o tratamento. Concluíram que nem o índice PAR ao final do tratamento, nem a quantidade de alterações oclusais ocorridas durante ou após o tratamento possibilitaram a previsão da quantidade ou do tipo de alteração oclusal em longo prazo. 
Melsen e Dalstra (2003) analisaram a estabilidade do movimento distal dos molares superiores provocado pelo AEB cervical. A amostra foi composta por 20 pacientes com má oclusão de Classe II, na fase da dentadura mista, com idade inicial variando de 8,1 a 10,4 anos. Antes de o tratamento iniciar-se, foram inseridos marcadores intraósseos de titânio, sendo quatro na maxila e cinco na mandíbula. Os pacientes utilizaram o AEB cervical 12 horas por dia, por um período de oito meses. Os autores concluíram que a relação de Classe I obtida com o AEB não se mostrou mais estável quando comparada aos aparelhos funcionais ou aos aparelhos intrabucais.

Janson et al. (2004) avaliaram cefalometricamente a estabilidade das alterações do tratamento com o aparelho extrabucal conjugado ao Ativador seguido de aparelhos fixos, após um período médio de 5 anos. Os resultados demonstraram uma estabilidade em longo prazo das alterações dentoalveolares anteroposteriores. Semelhantemente, as posições anteroposteriores da maxila e da mandíbula não exibiram recidiva no período pós-tratamento. Entretanto, houve ligeira recidiva da correção da relação maxilomandibular, provavelmente por ter a maxila retomado o seu desenvolvimento normal e a mandíbula ter apresentado uma velocidade de crescimento significantemente inferior ao grupo controle. $O$ trespasse vertical revelou uma recidiva estatisticamente significante e diretamente proporcional a quantidade de sua correção. Além disso, a avaliação individual dos pacientes, baseada na relação molar, demonstrou uma recidiva em 13,05\% dos casos. Essa recidiva mostrou-se relacionada à rotação horária da mandíbula, a redução do ângulo SNB e ao aumento de Co-A, todos significantes, no período pós-tratamento.

Ciger, Aksu e Germec (2005) estudaram as alterações pós-tratamento e póscontenção de 18 pacientes com má oclusão de Classe II, divisão 1 tratados com AEB cervical e aparelhos fixos e sem extrações. Foram avaliados os modelos e os cefalogramas, em média 5,3 anos pós-contenção. Os resultados pós-contenção demonstraram que a maxila permaneceu estável, a mandíbula se moveu para anterior, e o overjet aumentou suavemente (em média 1,25 mm). Com relação às variáveis estudadas nos modelos, os índices de irregularidade superior e inferior diminuíram com o tratamento e aumentaram após a remoção das contenções. No estudo de Pirttiniemi et al. (2005) os autores pesquisaram os efeitos em longo prazo do tratamento precoce com o aparelho extrabucal (AEB) nas estruturas craniofaciais. A amostra se compôs de 68 crianças com idade média de 7,6 anos, com uma 
tendência a oclusão de Classe II e um apinhamento moderado. A amostra foi dividida em 2 grupos. No primeiro, o tratamento com AEB foi iniciado imediatamente. No segundo, que serviu como controle, apenas procedimentos interceptores mínimos foram realizados durante dois anos. Após esse período, nos oito anos seguintes, este grupo recebeu tratamento ortodôntico com aparelhos fixos e, quando necessário, extrações. Os resultados demonstraram que a diferença mais evidente entre os grupos foram os arcos dentários mais amplos e longos no grupo com AEB, o que pode ser apenas parcialmente explicado pela alta taxa de extrações no grupo controle. Com relação às medidas cefalométricas, a diferença mais significante foi na orientação do plano maxilar. O índice PAR, mostrando o resultado geral do tratamento, obteve médias similares nos 2 grupos, na última avaliação realizada (pós-contenção). A deficiência do tratamento precoce com o AEB foi a média de tratamento total mais longa, resultando do tratamento em 2 fases.

Alessio Jr (2009) analisou cefalometricamente e, por meio de modelo de estudo, a estabilidade das alterações decorrentes do tratamento da má oclusão de Classe II, corrigida com o aparelho Pendulum, seguido de aparelhagem ortodôntica fixa, 5 anos pós-tratamento. A amostra consistiu de 20 pacientes (14 do gênero feminino e 6 , do masculino). Os resultados mostraram uma grande estabilidade das variáveis cefalométricas, sendo estatisticamente diferentes somente a inclinação do primeiro molar e a posição anteroposterior do lábio superior. Notou-se a inclinação para mesial do primeiro molar superior durante o período controle avaliada pelo ângulo MS.PP. A avaliação do índice PAR demonstrou que o tratamento com 0 aparelho Pendulum seguido pelo aparelho fixo foi estável 5 anos pós-tratamento, concluindo que o tratamento da Classe II com o aparelho Pendulum e o aparelho fixo foi estável em longo prazo. No entanto, sugere-se uma melhor avaliação da inclinação axial dos primeiros molares superiores através da radiografia panorâmica que se destacou por ser um método confiável para a tomada de medidas angulares, sendo, portanto, um método mais preciso para a visualização da real posição da inclinação das coroas dos molares (URSI et al., 1990). Visto que a avaliação da inclinação dos molares na cefalometria pode levar a resultados falso-positivos devido a sobreposição dos dentes do lado direito e esquerdo. 


\subsection{Considerações sobre a radiografia panorâmica em ortodontia}

\subsubsection{Histórico}

Preliminarmente cumpre-nos esclarecer a grande diversidade de termos existentes para se referir às radiografias panorâmicas. Com o intento de não prejudicar a compreensão dos textos revisados, optou-se por discorrer sucintamente sobre esta divergência terminológica. Os termos pantomografia, pantomograma, ortopantomografia, radiografia ortopantomográfica, ortopantomograma, panoramografia, radiografia rotatória, elipsopantomografia, elipsopantomograma e radiografia panorâmica, todos sinônimos, são utilizados para designar a técnica radiográfica que permite a visualização de toda a região maxilomandibular e estruturas adjacentes, com uma ou, no máximo, duas exposições (ALVARES; TAVANO, 1993; FREITAS; ROSA; SOUZA, 1998).

Com o intuito de se obterem exames radiográficos com um padrão de qualidade da imagem considerado tecnicamente bom, com o máximo de nitidez, mínimo grau de distorção e com grau médio de contraste, desenvolveram-se várias técnicas radiográficas, entre elas a técnica da radiografia panorâmica que permitia a visualização de toda a região maxilomandibular e estruturas adjacentes em um único filme radiográfico (FREITAS, 1993; FREITAS; TORRES, 1998).

Foi em 1948 que o finlandês Paatero (1948) publicou o primeiro artigo científico relatando a utilização da pantomografia, que consistia em um novo método tomográfico empregado para radiografar uma superfície curva em uma película radiográfica e que se limitava apenas à realização de radiografias da região do crânio. Paatero (1948) foi o responsável pelo desenvolvimento do primeiro aparelho e obtenção da primeira radiografia de uma pessoa, o que demonstra como este pesquisador representa um marco histórico para a Odontologia. Seus estudos constituem a base do aprimoramento de praticamente todos os aparelhos panorâmicos.

Desse modo, Nelsen e Kumpula (1952) descreveram um novo aparelho para obtenção da denominada radiografia panorâmica, que sensibilizava automaticamente a película radiográfica e produzia a imagem de todo o arco dentário. Os autores enfatizaram que a técnica da radiografia panorâmica não iria substituir a da radiografia intrabucal, e sim, complementá-la. Além disso, o paciente 
devia estar posicionado corretamente durante a tomada radiográfica, mantendo uma relação adequada com o filme radiográfico e a fonte de radiação para que o profissional obtivesse uma imagem radiográfica com qualidade.

Dois anos mais tarde, Paatero (1954) publicou um artigo no qual explicava o novo método radiográfico para obtenção da pantomografia e o funcionamento do aparelho que consistia em uma cadeira motorizada, um porta-filme giratório e uma fonte de raios $X$ imóvel. No momento da obtenção da pantomografia de uma estrutura curva como o crânio, o objeto e a película radiográfica giravam com uma velocidade idêntica e em direção opostas e o filme deveria apresentar o formato semelhante ao do arco dentário. Assim, como Nelsen e Kumpula (1952), Paatero (1954) relatou inúmeros fatores que poderiam interferir na obtenção de uma radiografia com boa qualidade de imagem, havendo entre esses fatores, um destaque para o correto posicionamento da cabeça do paciente durante a obtenção da radiografia panorâmica. Para ser possível uma boa imagem, o Plano de Frankfurt deveria apresentar-se paralelo ao plano do solo, podendo, porém, clinicamente, o Plano de Camper ser utilizado como referência.

Em 1956, Blackman constatou que, para evitar a formação de imagens maiores que o objeto, o porta-filmes deveria receber um contorno tal que se aproximasse à forma dos arcos dentários e o paciente deveria ser posicionado com o plano de Camper ou de Frankfurt paralelo ao plano horizontal. Na prática clínica, no entanto, tornou-se necessário, também, o uso do plano oclusal como referência para o posicionamento correto do paciente. Além disso, afirmou que a pantomografia não pretendia substituir os métodos radiográficos intra e extrabucais já existentes, mas sim, melhorar os meios de diagnóstico odontológico e que o objetivo atual dos pesquisadores era aperfeiçoar o aparelho para, então, empregá-lo na obtenção de radiografias de crianças, o que permitiria a realização de uma pesquisa longitudinal sobre o processo de erupção dentária.

Em 1960, Blackman continuou a difundir este método de visualização das estruturas dentoesqueléticas e declarou que a técnica permitia o exame de pacientes em qualquer idade, podendo ser utilizada como rotina.

No ano seguinte, Paatero (1961) apresentou um novo aparelho radiográfico denominado de Ortopantomógrafo, que utilizava três eixos de rotação independentes, diferente dos primeiros aparelhos desenvolvidos que apresentavam apenas um ou dois eixos de rotação. Com o Ortopantomógrafo tornou-se possível a 
obtenção das ortopantomografias, que possibilitavam a visualização de toda a área da maxila e da mandíbula que eram projetadas perpendicularmente em um filme radiográfico.

Depois de um correto desenvolvimento do aparelho radiográfico, muitos estudos foram realizados a partir dessa técnica radiográfica. No próximo tópico serão abordados os trabalhos relativos à fidelidade da medição angular em radiografias panorâmicas.

\subsubsection{Fidelidade das medidas angulares}

Kane (1967) desenvolveu um cefalostato que foi construído para adaptar-se ao aparelho da marca comercial Panorex. Em sua pesquisa, Kane concluiu que o aparelho panorâmico, quando associado ao novo cefalostato, promoveria um futuro maravilhoso para as pesquisas odontológicas, principalmente na ortodontia porque era capaz de reproduzir a mesma imagem em duas radiografias diferentes com um alto grau de precisão, permitindo, assim, a avaliação das alterações da posição dentária, a angulação e o paralelismo radicular dos dentes, a quantidade de perda de ancoragem e o grau de nivelamento dentário, fatores importantes que deveriam ser avaliados antes e após o tratamento ortodôntico.

Com 0 intuito de verificar se as radiografias panorâmicas poderiam documentar a movimentação ortodôntica, Hauck (1970) desenvolveu um estudo no qual avaliou 10 pacientes tratados ortodonticamente com extrações dos quatro primeiros pré-molares. Realizou o acompanhamento da trajetória dos caninos durante o movimento de retração, tendo sido obtidas 11 radiografias de cada paciente, uma inicial e as outras 10 conseguidas mensalmente após o início do tratamento. Todas as radiografias foram realizadas no aparelho da marca Panorex juntamente com a utilização de um cefalostato para auxiliar no reposicionamento do paciente. Após a obtenção das radiografias, realizaram-se os traçados e as sobreposições seriadas utilizando como referência a borda inferior da mandíbula e o plano palatino da maxila. As sobreposições foram separadas por quadrantes, o que possibilitou a determinação da quantidade de movimento dos caninos, a quantidade de perda de ancoragem dos dentes posteriores e o centro de rotação dos dentes. Os resultados desse estudo permitem concluir que a obtenção da radiografia panorâmica e a utilização do cefalostato tornaram viável uma reprodução confiável 
do posicionamento do paciente possibilitando a análise da trajetória dos caninos durante o movimento de retração. Além disso, o autor recomendou o uso da radiografia panorâmica em estudos longitudinais para avaliar o paralelismo radicular, o grau de reabsorção radicular e do padrão de erupção dentária, e para acompanhar as intervenções cirúrgicas e o tratamento ortodôntico.

Frykholm et al. (1977) relataram a importância da determinação da inclinação dentária para a ortodontia e a cirurgia bucal e a dificuldade de determinar essa inclinação por meio das técnicas radiográficas existentes, sendo que a imagem da ortopantomografia era considerada duvidosa em todos os tipos de mensurações devido à existência das distorções inerentes à imagem radiográfica. Diante disso, os autores verificaram a confiabilidade das mensurações angulares na ortopantomografia, utilizando um objeto-teste que era curvo, com a forma aproximada de um arco dentário, com três esferas de metal fixadas na região de incisivo, canino e segundo molar. Posicionou-se o objeto-teste no Ortopantomógrafo e obteve-se uma série de radiografias simulando diversas situações clínicas. Após a avaliação dos resultados alcançados, pode-se concluir que a imagem produzida pelo Ortopantomógrafo revelou-se um meio auxiliar de diagnóstico confiável para as mensurações angulares de estruturas posicionadas obliquamente, como os dentes.

Preocupados com a avaliação do paralelismo radicular, Phillip e Hurst (1978) pesquisaram as distorções radiográficas em diferentes inclinações do plano oclusal. Um dispositivo aparentando o arco dentário acomodou fios ortodônticos no sentido vertical representando os dentes, soldados perpendicularmente a um fio de maior calibre, simulando o plano oclusal. Após várias tomadas radiográficas diversificando o posicionamento do dispositivo, foram medidos os ângulos entre os fios verticais e o horizontal e pode-se concluir que as alterações de até $5^{\circ}$ não apresentavam significado clínico para determinação do relacionamento dos longos eixos dentários. Dessa forma, o significado clínico dessa pesquisa resume-se ao conhecimento de que ocorre uma pequena quantidade de distorção e esta varia de acordo com a inclinação do plano oclusal. A radiografia panorâmica eliminou os problemas de sobreposições, embora tenha apresentado o problema da magnificação da imagem o que tornava as medidas quantitativas difíceis de serem determinadas com exatidão.

Considerando a importância da determinação dos fatores etiológicos na erupção ectópica dos primeiros molares permanentes superiores, Bjerklin e Kurol 
(1983) pesquisaram os dois tipos de erupção ectópica existente em 129 crianças com idade média de 8,6 anos. O primeiro tipo considerado reversível ocorria quando o primeiro molar conseguia irromper sozinho e o segundo, o irreversível, quando o primeiro molar permanecia em contato com a região cervical da face distal do segundo molar decíduo e não conseguia irromper para sua posição normal no arco dentário, mantendo-se impactado. Para este estudo, utilizaram-se telerradiografias, modelos de gesso e, devido à dificuldade da determinação da inclinação axial na telerradiografia oriunda da sobreposição das imagens, as medições foram obtidas nas radiografias panorâmicas, utilizando como referência uma linha horizontal que passava pelos pontos mais inferiores da imagem das órbitas. Sabendo da existência das distorções na radiografia panorâmica devido a um posicionamento incorreto da cabeça do paciente, obtiveram-se radiografias em um crânio com variações de ângulos de 5, 10 e 15 graus para cima e para baixo, e concluíram que, quando a cabeça estava posicionada 5 graus para cima, as medidas angulares diminuíam e, quando inclinava-se para baixo os ângulos aumentavam. As radiografias com $10 \mathrm{e}$ 15 graus de alteração não foram aceitas clinicamente. Os autores concluíram que, nos casos de erupção irreversível, se os primeiros molares apresentavam uma inclinação axial para mesial maior antes das extrações dos segundos molares decíduos, essa inclinação mantinha-se após a realização da extração e que os dentes que irrompiam normalmente apresentavam uma inclinação axial para mesial menor do que os dentes impactados.

Preocupados com a presença das distorções lineares em graus variados das radiografias panorâmicas, e considerando a importância dessa radiografia no diagnóstico e no acompanhamento do tratamento ortodôntico, Samawi e Burke (1984) realizaram um estudo avaliando a magnitude e a distribuição das distorções angulares na radiografia panorâmica. Para desenvolver esse estudo, utilizou-se uma estrutura metálica curvada simulando a forma e a dimensão dos arcos dentários de um jovem de 12 anos de idade e marcadores de chumbo foram posicionados paralelamente entre si representando o longo eixo dentário e algumas estruturas anatômicas para verificar a exatidão da projeção dessas estruturas no filme radiográfico. Após essa ação, efetuaram-se diversas exposições radiográficas da estrutura metálica variando o posicionamento no sentido vertical e horizontal. Os autores concluíram que as distorções angulares foram influenciadas diretamente pelas alterações na inclinação da cabeça do paciente durante a tomada radiográfica 
e a região dos caninos e pré-molares em ambos os arcos dentários apresentaram a maior quantidade de distorção angular, devendo, por isso, as medidas angulares dessas áreas ser interpretadas com certo cuidado. Além disso, observou-se que a variação da distorção linear não necessariamente vinha acompanhada pelas distorções angulares, por isso a região dos terceiros molares e as estruturas esqueléticas projetadas na parte inferior da radiografia apresentaram um menor grau de variação na distorção, podendo ser utilizadas com fidelidade para a realização de pesquisas.

Dois anos depois Larheim e Svanaes (1986) encetaram uma pesquisa com objetivo de comparar a reprodutibilidade de medições lineares horizontais, verticais e, ainda, das medições angulares na região mandibular. Para essa investigação realizaram tomadas radiográficas seriadas de pacientes e crânios secos utilizando um aparelho Siemens, com intervalos de tempo variados. Em virtude da variação da distorção, as medidas lineares no sentido horizontal pareceram imprecisas, apesar de tanto as medidas lineares verticais quanto as medidas angulares mostraram-se fidedignas, contando que as radiografias fossem produzidas por um único operador.

Assim, Lucchesi, Wood e Nortjé (1988) encetaram um estudo para investigar a validade da radiografia panorâmica na avaliação da inclinação axial mesiodistal dos dentes posteroinferiores e para determinar, de maneira quantitativa, as diferenças existentes entre as inclinações reais e as obtidas pela mensuração nessa modalidade de radiografia. Para realizar esse estudo, utilizou-se um modelo com pinos metálicos que simulavam o posicionamento radicular e obtiveram-se dois tipos de radiografias, a panorâmica e a obtida pela técnica do filme plano. Os autores concluíram que a técnica radiográfica do filme plano apresentou os valores das inclinações axiais mais próximos da realidade do que a radiografia panorâmica.

Diante da necessidade da determinação da inclinação mesiodistal dos longos eixos dentários para melhorar o diagnóstico do tratamento ortodôntico, Tavano et al. (1989) verificaram, por meio de um estudo, a possibilidade de estabelecer linhas de referência para avaliar a inclinação axial mesiodistal dentária. Ao analisarem os fatores relacionados à facilidade de visualização radiográfica e pequena modificação de posicionamento promovida pelo crescimento e desenvolvimento da face ou pelo tratamento ortodôntico, determinaram que a linha que apresentava melhor comportamento para avaliar os dentes superiores foi a linha interorbital, que passa pelos pontos mais inferiores das cavidades orbitárias, e, para os dentes inferiores, a 
linha intermentoniana, que passa pelos pontos mais centrais dos forames mentonianos.

No ano de 1989, Ursi destacou a radiografia panorâmica como um método confiável para tomada de medidas angulares e estabeleceu valores padrão para as inclinações axiais mesiodistais. Em seu estudo, Ursi (1989) utilizou uma amostra de 42 jovens brasileiros leucodermas de origem mediterrânea, com idades entre 12 e 17 anos, que apresentavam uma oclusão "normal". Além disso, comparou também os valores dessas inclinações em radiografias obtidas em quatro diferentes aparelhos panorâmicos e concluiu que o aparelho de marca comercial Funk podia ser utilizado como referência para o uso clínico, apesar de os valores apresentarem diferenças estatisticamente significantes entre os aparelhos. $O$ autor ainda determinou os valores médios normais para as inclinações axiais mesiodistais dos dentes permanentes irrompidos, os quais serviriam de parâmetro para a realização de uma análise comparativa dos valores iniciais, como daqueles durante e após o tratamento ortodôntico, o que auxiliaria na obtenção de uma oclusão estável.

No ano de 1998, Catic et al. avaliaram a precisão das medidas lineares e angulares da mandíbula nas imagens obtidas pela radiografia panorâmica, utilizando 25 mandíbulas dissecadas, sendo que 16 eram de homens e 9, de mulheres, com idade de 27 a 78 anos, e empregaram marcadores metálicos como pontos de referências. Cada mandíbula foi radiografada em um aparelho panorâmico da marca Siemens. Obtiveram-se as radiografias e realizaram-se as medições lineares verticais, horizontais e oblíquas e as medições angulares diretamente nas mandíbulas dissecadas e, posteriormente, nas radiografias panorâmicas e compararam-se os resultados obtidos. Os autores concluíram que os valores das medidas horizontais que atravessavam a linha média da mandíbula, estendendo-se do processo condilar direito ao esquerdo, foram muito maiores do que os valores obtidos para a mesma distância verificada na mandíbula dissecada, ou seja, a radiografia panorâmica permite medidas precisas horizontais desde que as distâncias não ultrapassem a linha média da mandíbula. Assim, tornou-se possível utilizar a radiografia panorâmica para avaliar as medidas lineares verticais, horizontais e oblíquas e as medidas angulares, desde que se realizassem as medições em apenas um lado na mandíbula.

Considerando que a imagem da radiografia panorâmica sofria influência do posicionamento da cabeça do paciente e que isso poderia interferir negativamente 
na avaliação da inclinação axial mesiodistal dentária, Mckee et al. (2001) avaliaram os efeitos da variação do posicionamento da cabeça no sentido horizontal e vertical sobre a imagem da inclinação axial mesiodistal na radiografia panorâmica e compararam esses resultados com a imagem obtida com um correto posicionamento da cabeça. Os autores utilizaram um crânio humano como base para um typodont que foi radiografado repetidas vezes com um correto posicionamento da cabeça e com variações de $5^{\circ}$ para cada lado e $5^{\circ}$ para cima e para baixo. Os resultados analisados concluíram que a maioria dos valores angulares resultantes dos diferentes posicionamentos da cabeça foi diferente estatisticamente dos valores obtidos com o correto posicionamento. Os dentes superiores foram mais sensíveis às alterações no sentido vertical, sendo que a rotação para cima promoveu uma projeção mesial das raízes e para baixo, uma projeção distal. Portanto, concluiu-se que a avaliação da inclinação axial mesiodistal dos dentes por meio da panorâmica deveria ser realizada com extrema cautela.

Em 2002, Mckee et al. descreveram as vantagens da radiografia panorâmica, destacando a sua utilização para uma correta avaliação clínica antes, durante e após o tratamento ortodôntico na verificação do paralelismo radicular e da inclinação axial mesiodistal dentária. Baseados nisso, os autores compararam as inclinações mesiodistais determinadas em um typodont e um crânio seco, com a imagem radiográfica obtida em quatro aparelhos panorâmicos contemporâneos (OP 100, Cranex 3+, Orthophos, PM 2002 EC) com uma padronização do posicionamento da cabeça. Montou-se o typodont e determinou-se a verdadeira inclinação axial mesiodistal relativa ao arco ortodôntico por meio de uma máquina tridimensional e por um programa de computador desenvolvido especialmente para determinar essas medidas. Um crânio humano serviu de suporte para o typodont que foi repetidamente radiografado e reposicionado cinco vezes em cada aparelho panorâmico. As imagens radiográficas foram escaneadas e digitalizadas pelo programa de computador para determinar o valor das inclinações axiais mesiodistais de cada dente. Os resultados revelaram que a maioria dos valores angulares (74\%) obtidos pelos quatro aparelhos radiográficos apresentaram uma diferença estatisticamente significante em relação aos valores angulares reais. Para os dentes superiores, as imagens das raízes anteriores foram projetadas mais para a mesial, enquanto as das raízes posteriores mais para a distal, criando a impressão de uma exagerada divergência radicular entre o canino e o primeiro pré-molar, sendo que, 
na verdade, havia uma convergência ou até mesmo um paralelismo radicular. $\mathrm{O}$ arco inferior apresentou uma discrepância entre as inclinações da radiografia maior que os valores do arco superior, sendo que a imagem projetada apresentava quase todas as raízes inclinadas mais para a mesial do que realmente estavam e os caninos e os primeiros pré-molares eram os dentes mais afetados também. A maior diferença angular ocorreu entre o incisivo lateral inferior e o canino, onde o paralelismo radicular existente era projetado como uma convergência radicular. Portanto, concluiu-se que a avaliação clínica da inclinação mesiodistal deve ser abordada com extrema cautela e com certo conhecimento da existência da distorção da imagem na radiografia panorâmica.

Stramotas et al. (2002) avaliaram a exatidão das medições lineares e angulares a partir de radiografias panorâmicas tomadas em várias posições. Um modelo que representa a dentição e o plano oclusal funcional foi desenvolvido utilizando uma estrutura de acrílico e fios de aço inoxidável. O objetivo foi investigar se a variação da posição do modelo afetava as medidas lineares e angulares em radiografias panorâmicas. Quatro posições diferentes foram investigadas. Esse estudo indicou que a comparação de medidas lineares e angulares em panorâmicas tomadas em momentos diferentes é suficientemente necessária para medir as alterações no comprimento e paralelismo das raízes e para medir a angulação dos terceiros molares em desenvolvimento. Esses resultados sugerem que a medida exata das estruturas na panorâmica é possível, desde que tomadas as devidas precauções em relação ao posicionamento da cabeça. Alguma variação na posição da cabeça é possível de ser tolerada desde que o plano oclusal não esteja inclinado mais de 10 graus.

\subsection{Inclinação axial dos dentes}

Dewel (1949) observou que os dentes apresentavam uma grande tendência de se inclinarem para mesial mesmo antes de alcançarem o plano oclusal e ocluírem com os dentes antagonistas, e, quando havia qualquer alteração fora do normal, como uma força promovida pelos lábios ou pela língua, ocorria um aumento dessa inclinação mesial, ou uma rotação dentária de um ou mais dentes. De acordo com o referido autor, o contato proximal entre os dentes é proporcionado por esta inclinação mesial específica, não somente na época da irrupção, mas também nos 
anos posteriores, quando os dentes sofrem desgastes pela própria função na cavidade bucal, mas permanecem unidos pelo componente anterior de forças, que seria ativado pela pressão funcional de oclusão dos dentes antagonistas inclinados na mesma direção.

Ciente da importância do correto posicionamento mesiodistal dos longos eixos dentários para a manutenção da estabilidade dos resultados obtidos pelo tratamento ortodôntico, Holdaway (1952) sugeriu a incorporação de angulações nos braquetes substituindo as dobras de segunda ordem nos fios de nivelamento. Segundo o autor, os braquetes devem ser angulados para compensar a folga do fio ortodôntico dentro de suas canaletas nos dentes submetidos a maiores movimentações. Este artifício também pode ser empregado no preparo de ancoragem e na substituição das dobras artísticas, resultando numa inclinação mais divergente dos longos eixos dentários, e proporcionando uma anatomia mais natural, principalmente no segmento anterossuperior do arco dentário. $O$ autor alertou ainda que muitos casos eram concluídos sem a obtenção do paralelismo radicular. Nos locais das extrações, as raízes dos dentes adjacentes apresentavam uma configuração em "V", sendo este um dos fatores predisponentes à reabertura de espaço. Assim, com a angulação incorporada ao braquete, tornou-se mais fácil a obtenção do paralelismo radicular e estabilidade pós-tratamento ortodôntico. Porém, o autor destacou a importância da realização de uma técnica adequada, porque o fato de a angulação estar incorporada ao braquete não diminuía a necessidade de uma técnica cuidadosa, principalmente na fase inicial. Por conseguinte, seria possível obter melhores resultados com menor esforço do que quando se utilizava a forma convencional de posicionamento de braquete e realização das dobras de segunda ordem nos fios.

Beyron (1952) realizou um estudo sobre a relação oclusal existente entre a maxila e a mandíbula, e concluiu que as forças oclusais geradas pela mastigação deveriam ser distribuídas pelo maior número de dentes e, de preferência, na direção dos longos eixos dentários.

Ainda em 1952, buscando estabelecer os fatores relacionados ao sucesso e à estabilidade do tratamento ortodôntico, Strang (1952) observou que o posicionamento axial de cada dente poderia apresentar-se normal ou propositadamente modificado para resistir melhor a qualquer força que gerasse estresse e promovesse uma recidiva da má oclusão indicando que o procedimento 
ortodôntico corretivo deveria levar em consideração o relacionamento final das coroas e raízes dentárias.

Dempster, Adams e Duddles (1963) estudaram a disposição, inclinação e angulação das raízes dos dentes irrompidos na maxila e na mandíbula. Este tipo de estudo nunca havia sido realizado anteriormente, porque quando os autores discutiam sobre a forma do arco dentário, eles se referiam à parte da coroa dentária exposta na cavidade bucal. Essa pesquisa analisou principalmente a parte do dente que permanecia escondida, ou seja, as raízes que, até essa época, eram analisadas por meio dos dentes extraídos, radiografias ou cortes histológicos. Os autores desenvolveram um estudo qualitativo e quantitativo da disposição radicular, com o objetivo de determinar as inclinações axiais mesiodistais e vestibulolinguais de todos os dentes, utilizando-se 11 crânios secos que apresentavam dentadura permanente completa. Confeccionou-se um canal nos dentes com uma broca longa, no qual foram inseridos fios ortodônticos e obtiveram-se telerradiografias de norma lateral e frontal e fotografias dos crânios. Os autores determinaram valores médios para essas inclinações e concluíram que os longos eixos dos dentes não convergiam para uma única direção.

Young (1964) observou que cada dente encontra-se posicionado conforme o tipo de esforço requisitado, sendo que as suas distintas inclinações correspondem a um modelo perfeito de estabilidade sob função. A inclinação para distal de seus ápices possibilita a oclusão de dois dentes antagonistas numa posição bastante vantajosa, permitindo que a força oclusal seja transmitida paralelamente às suas raízes sem causar danos aos dentes e aos tecidos de sustentação.

No ano seguinte, Wheeler (1965) relatou que, nos estudos relacionados à anatomia e à oclusão dentária, era comum existirem variações dentro de uma mesma característica, mas certas tendências deveriam ser pesquisadas, pois poderiam exercer um papel importante na obtenção de novas informações sobre o assunto. Segundo o autor, os dentes não se apresentavam posicionados verticalmente no osso alveolar, o que promoveria uma má distribuição das forças mastigatórias, apresentando, ao contrário, como tendência, a inclinação dos longos eixos dentários para distal. Embora estudos realizados em diferentes crânios demonstravam que havia discrepâncias quanto aos valores absolutos da inclinação das coroas para mesial, comprovou-se que havia essa tendência de inclinação, porém em graus variáveis. Wheeler (1965) descreveu também que cada dente 
apresentava a inclinação que melhor resistia às forças mastigatórias e se algum dente encontrava-se mal posicionado, ocorria uma deficiência de sua função e estabilidade e a correta disposição no arco dentário garantia a manutenção dos pontos de contato proximais dentários e a correta dissipação das forças funcionais.

Compulsando a literatura pertinente à estabilidade dos casos ortodonticamente tratados, Graber (1966) constatou que a reabertura de espaços nos locais das extrações era consequência do paralelismo radicular inadequado.

O argumento de Wheeler (1965) corroborou com as opiniões de Sicher e Dubrul (1970) que afirmaram que as distintas posições dos dentes no osso alveolar coincidem com a direção das forças mastigatórias resultantes nesse ponto, sendo que esta obliquidade axial reflete a direção das forças exercidas pelos músculos elevadores da mandíbula.

No ano seguinte, Garino (1971) pesquisou sobre a inclinação axial mesiodistal dos dentes e concluiu que eles mostravam diferentes inclinações axiais e em graus variados. Os dentes superiores apresentavam seus ápices inclinados para distal obedecendo a um padrão de inclinação axial mesiodistal normal que aumentava progressivamente dos incisivos para os pré-molares. O primeiro molar, entretanto, encontrava-se verticalizado na base óssea e o ápice dos outros molares apresentavam-se inclinados para mesial. No arco inferior, os incisivos estão verticalizados e a partir do canino ocorre um aumento gradativo das inclinações dos ápices para distal.

Com o intuito de prevenir a recidiva em casos tratados ortodonticamente com extração, Edwards (1971) analisou 20 sítios de extração (10 pacientes com duas extrações). $O$ autor sugeriu uma cirurgia periodontal para eliminar a dobra gengival provocada pela movimentação ortodôntica, reduzindo, desta forma, o número de recidivas de reabertura de espaços. O paralelismo radicular e o contato justo dos dentes aproximados também constituem outro fator de estabilidade dos casos tratados com extração.

As inclinações axiais mesiodistais atingiram seu grau máximo de importância para o tratamento ortodôntico quando Andrews (1972) elaborou uma das mais brilhantes descrições da morfologia da oclusão normal e publicou o grande clássico da ortodontia "As seis chaves para a oclusão normal". Antes desse trabalho, os ortodontistas possuíam como referência os guias de Angle, representados pela relação molar normal, na qual a cúspide mesiovestibular do primeiro molar superior 
ocluia no sulco mesiovestibular do primeiro molar inferior. O autor avaliou, em seu estudo, 120 modelos de gesso de pacientes que não se submeteram ao tratamento ortodôntico, cujos dentes estavam alinhados e esteticamente agradáveis, oclusão aparentemente normal, e pacientes que não se beneficiariam com a realização do tratamento ortodôntico. Após avaliar as coroas dentárias nos modelos de gesso, o autor determinou seis características ou seis "chaves" que estavam presentes em uma oclusão normal, entre as quais, a inclinação axial mesiodistal ou angulação coronária. A inclinação axial referia-se apenas à angulação da coroa e não do longo eixo dentário. $\mathrm{O}$ autor relatou que as porções cervicais dos longos eixos das coroas dentárias encontravam-se inclinadas mais para distal do que a porção incisal e essa inclinação variava de acordo com o tipo de dente. A oclusão normal dependia da inclinação distal correta da coroa dentária, especialmente na região dos dentes anterossuperiores que apresentam as coroas mais alongadas. O grau de inclinação dos incisivos determinava a quantidade de espaço consumida no arco dentário e exercia um efeito considerável na oclusão posterior e no aspecto estético da região anterior.

No ano de 1974, Glickman desenvolveu um estudo para avaliar as forças oclusais e concluiu que as forças decompunham-se em diversas direções em função da inclinação axial dos longos eixos dos dentes e promoviam uma movimentação de todos os dentes no sentido mesial devido à existência do componente anterior de força. Esta força era transmitida por meio dos pontos de contatos proximais da região posterior para a região anterior e ocorria uma neutralização da mesma na linha média, porque havia o encontro de duas forças semelhantes em direções opostas.

No ano seguinte, após avaliar o posicionamento dentário obtido ao final do tratamento ortodôntico quando se utilizava o aparelho edgewise, Renfroe (1975) preconizou a colocação dos acessórios ortodônticos paralelamente às faces oclusais e incisais dos dentes, obtendo, assim, uma adequada inclinação axial mesiodistal dos dentes em relação ao plano oclusal, relatando, além disso, que, na dentadura permanente, as coroas dentárias apresentavam-se inclinação para a mesial, o que proporcionava uma estética agradável e uma adequada função oclusal.

Objetivando avaliar uma oclusão estática que correspondesse às necessidades funcionais Andrews (1976) novamente correlacionou os vários aspectos das suas "chaves para a oclusão normal" à função desenvolvida. 
Relacionou a correta inclinação mesiodistal das coroas dos dentes anteriores à obtenção de pontos de contato satisfatórios e ao preenchimento de espaço no arco dentário, posicionando corretamente os dentes posteriores, com pontos de contatos proximais cerrados, contribuindo, também, com a estética desta região. $O$ autor preconizou diferentes graus de inclinação para os dentes superiores. Para os incisivos centrais e laterais, recomendou angulações de $50^{\circ}$ e $90^{\circ}$, respectivamente, proporcionando pontos de contatos adequados, estética e função satisfatória, além de permitir um correto posicionamento dos dentes no arco dentário. Os caninos superiores apresentariam inclinação de $110^{\circ}$, de maneira que, durante os movimentos de lateralidade, estes contatassem apenas com seus homólogos inferiores. Se os caninos superiores se apresentassem muito verticalizados, poderiam interferir, em alguns movimentos excursivos, com os primeiros pré-molares inferiores e permitiriam uma desoclusão posterior prematura comprometendo a oclusão anterior mutuamente protegida. Porém, a desoclusão posterior, durante o movimento protrusivo, pode tornar-se prejudicada se os caninos superiores estiverem excessivamente inclinados para mesial. No caso dos pré-molares, para que suas cúspides vestibulares deslizem sem toque entre as cúspides dos dentes antagonistas nos movimentos de lateralidade, estes devem apresentar uma posição relativamente vertical. Já os molares superiores necessitam de uma inclinação distal de seu longo eixo para proporcionar um contato adequado com seus antagonistas.

Nesse mesmo ano, interessado na avaliação do paralelismo radicular dos dentes aproximados para fechar o espaço, Hatasaka (1976) encetou um estudo com radiografias periapicais e interproximais de 28 pacientes tratados ortodonticamente com extração dos primeiros pré-molares. $O$ autor observou quatro possíveis situações de relacionamento radicular ao final do tratamento: raízes paralelas sem espaço entre as coroas, raízes divergentes, raízes convergentes sem toque dos ápices e raízes convergentes e ápices tocando. Uma nova avaliação nesses mesmos locais num total de 110 quadrantes foi efetivada depois de um período de contenção e pós-contenção variando de 1 a 13 anos. O autor concluiu que os melhores resultados, em termos de paralelismo radicular e manutenção do fechamento do espaço ao longo do tempo, incluíam os casos que apresentaram, ao término do tratamento, raízes paralelas com uma inclinação axial adequada e com quantidades proporcionais de osso de suporte. 
Dois anos mais tarde, estudando espécimes dissecados, Berkovitz, Holland e Moxham (1978) constataram a tendência ao paralelismo radicular e à inclinação dos ápices para distal corroborando com os estudos anteriores. E ainda afirmaram que as forças mastigatórias incidiam sobre as superfícies oclusais dos dentes com uma resultante no sentido mesial, podendo este fator estar relacionado às inclinações axiais dos dentes.

Ampliando as pesquisas sobre as forças oclusais e observando o periodonto de sustentação Goldman e Cohen (1983) consideraram que a manutenção dessas estruturas depende da axialidade dos esforços oclusais, pelo fato de que 2/3 das fibras do ligamento periodontal encontram-se direcionadas para suportar esse tipo de pressão. O componente anterior participa da dissipação das forças oclusais, sendo consequência da correta distribuição destas.

Em função da literatura se mostrar escassa com relação à avaliação das inclinações axiais mesiodistais dentárias, Mylnarska-Zduaniar (1983) realizou um estudo para determinar as médias e desvios-padrão das inclinações axiais dos longos eixos dos dentes permanentes irrompidos e dos germes dentários permanentes na época do primeiro período transitório da dentadura mista, por meio da utilização da pantomografia obtida no aparelho Panelipse, em uma amostra de crianças com oclusão "normal".

No ano seguinte, Vigorito (1984) descreveu, em seu trabalho, os detalhes considerados importantes para a correta montagem de um aparelho fixo utilizando a técnica edgewise. O autor relatou que, em relação ao posicionamento dos braquetes, estes deveriam apresentar-se posicionados paralelamente às bordas incisais ou oclusais dos dentes. Para que, ao final do tratamento ortodôntico, o profissional obtivesse o posicionamento artístico dos dentes, ou seja, uma correta inclinação axial mesiodistal, os incisivos centrais superiores deveriam apresentar uma angulação de $3^{\circ}$, os laterais superiores, de $4^{\circ}$ e os caninos superiores e inferiores, de $5^{\circ}$ no sentido distocervical e, para facilitar a colagem angulada dos acessórios, o autor sugeriu a construção de anguladores de $3^{\circ}, 4^{\circ}$ e $5^{\circ}$ confeccionados com o fio retangular.

$\mathrm{Na}$ tentativa de eliminar totalmente a contenção ortodôntica na região anteroinferior, Williams (1985) apresentou seu estudo longitudinal de 21 anos. Durante esse tempo, dedicou-se ao estudo da estabilidade pós-tratamento nessa região. Sugeriu que, ao término do tratamento, os incisivos inferiores apresentem os 
ápices mais inclinados para distal do que normalmente é observado, sendo os incisivos laterais mais que os incisivos centrais. Afirmou também que as coroas destes dentes tendem a apinhar quando as raízes encontram-se convergentes ou até mesmo paralelas.

Corroborando com a opinião de Vigorito (1984), em 1986, Interlandi recomendou que os braquetes dos incisivos superiores e caninos superiores e inferiores fossem angulados, na montagem do aparelho, para obtenção do posicionamento artístico eliminando, desta forma, a incorporação das dobras de segunda ordem nos segmentos anteriores dos arcos. Preconizou para os incisivos centrais superiores uma inclinação de $3^{\circ}$, para os laterais $4^{\circ}$ e para os caninos superiores e inferiores, $6^{\circ}$ e $5^{\circ}$, respectivamente.

Picosse (1990) desenvolveu um estudo para avaliar as características da oclusão e do posicionamento dentário. O autor descreveu, em seu trabalho, que, no arco superior, todos os dentes apresentavam seus longos eixos inclinados para distal, especialmente o primeiro molar, cuja cúspide distovestibular encontrava-se num plano mais inferior que a mesiovestibular. No arco inferior, o autor observou os mesmos padrões de inclinação citados por Garino (1971), ou seja, os incisivos apresentavam-se verticalizados e ocorria um aumento gradativo das inclinações axiais para distal a partir do canino até o último molar irrompido.

$\mathrm{Na}$ tentativa de estabelecer bases quantitativas para a avaliação das inclinações axiais mesiodistais de todos os dentes permanentes durante e após o tratamento ortodôntico, Ursi et al. (1990) realizaram um estudo que determinou os padrões médios normais dessas inclinações. Para os autores, um caso bem tratado ortodonticamente deveria exibir, radiograficamente, a mesma disposição radicular daquela presente na oclusão normal. No arco superior, os incisivos centrais e laterais de cada quadrante devem encontrar-se ligeiramente convergentes. Os caninos mantêm uma discreta inclinação para a distal, assim como os demais dentes, com exceção dos segundos molares que devem se apresentar inclinados para a mesial. Os incisivos inferiores devem aparecer verticalizados e, a partir dos caninos, os dentes remanescentes aumentam gradativamente a inclinação de seus ápices para a distal.

Interessados em avaliar os resultados da reabilitação bucal em adultos, Enacar, Altay e Haydar (1992) afirmaram que a associação da ortodontia e da periodontia aumentam o êxito dos tratamentos nesses pacientes. A correção da 
inclinação axial dos dentes, por meio de aparelhos ortodônticos, pode prevenir uma exposição pulpar durante o preparo protético e, também, melhorar as condições periodontais do paciente.

Capelozza Filho e Machado (1994) introduziram um novo método para avaliação da inclinação axial mesiodistal do primeiro molar superior pela radiografia panorâmica. Utilizaram cinco radiografias ortopantomográficas de casos tratados sem extrações e sobre estas foram traçados os contornos inferiores das órbitas, 0 contorno externo da mandíbula e os contornos externos dos primeiros molares superiores. Em seguida, traçaram-se os longos eixos destes dentes de duas maneiras distintas: primeiro, seguindo a direção da raiz palatina e, depois, a bifurcação das raízes vestibulares. Verificaram que o longo eixo do primeiro molar superior, quando traçado sobre a radiografia panorâmica orientado pelo canal radicular da raiz palatina, muitas vezes apresentava-se deslocado para mesial. Assim, concluíram que a utilização da bifurcação das raízes vestibulares mostrou-se mais estável e fiel, indicando valores de inclinação próximos a $90^{\circ}$ que corroboram com os achados clínicos, devendo ser adotada como rotina na determinação do posicionamento do primeiro molar superior.

Com o propósito de avaliar e comparar as inclinações axiais mesiodistais dos dentes ao final do tratamento ortodôntico, em casos tratados pelas técnicas edgewise e straigth wire, Capelozza Filho et al. (1994) empreenderam um estudo utilizando as radiografias panorâmicas de casos tratados sem extração. A amostra constituiu-se de 52 ortopantomografias sendo 26 do grupo 1 (edgewise) e 26, pertencente ao grupo 2 (straight wire). Os braquetes adotados na técnica de Andrews (straight wire) apresentavam angulações para os dentes superiores de 50 para os incisivos centrais, 90 para os laterais, 110 para os caninos, 20 para os prémolares e 50 para os primeiros molares. Na técnica edgewise, a colagem incluiu angulação dos incisivos centrais superiores de 50, incisivos laterais superiores de 30 , angulação um pouco mais acentuada dos caninos superiores variando entre $50 \mathrm{e}$ 70 e tubos dos primeiros molares superiores com inclinação de 30 . Da avaliação das radiografias panorâmicas verificaram uma única diferença consistente entre as duas técnicas de tratamento: maior inclinação axial mesiodistal dos caninos superiores na técnica straight wire. As demais diferenças foram clinicamente desprezíveis. Concluíram, ainda, que a radiografia panorâmica, como parâmetro para detectar erros e introduzir correções no posicionamento radicular dos dentes antes do 
término do tratamento, pode ser adotada como método morfológico coadjuvante ao exame clínico.

Capelozza Filho et al. (1999) verificaram a necessidade da individualização dos braquetes totalmente programados com a finalidade de se obter uma oclusão individualizada de acordo com o tipo de má oclusão e característica facial do paciente, diminuindo, desta forma, o número de dobras de qualquer ordem a ser realizado nos arcos. Esta individualização pressupõe colocar, nos braquetes dos dentes envolvidos na movimentação, características capazes de responder às exigências da mecânica adotada, preservando, imediatamente ao final do movimento, as características de posicionamento consideradas ideais. Para que as corretas inclinações axiais mesiodistais dos dentes fossem alcançadas, os autores sugeriram que os braquetes apresentassem angulações um pouco diferentes daquelas preconizadas para a técnica edgewise e também distintas das prescrições originais introduzidas por Andrews. Assim, recomendaram, para cada tipo de má oclusão (Classe I, II e III), braquetes individualizados em relação às angulações para os arcos superiores e inferiores como seguem: para más oclusões de Classe I, angulações de $5^{\circ}$ para os incisivos centrais e $9^{\circ}$, para os laterais superiores, e de $2^{\circ}$, para os incisivos inferiores; para os caninos superiores e inferiores, 8ㅇ e 5으, respectivamente; pré-molares superiores com $0^{\circ}$ e inferiores $2^{\circ}$, e braquetes sem angulação ( $\left.0^{\circ}\right)$ para os molares superiores e inferiores; nas más oclusões de Classe II, angulações apenas para os caninos superiores ( $\left.5^{\circ}\right)$ e incisivos inferiores $\left(2^{\circ}\right)$ e, para as más oclusões de Classe III, braquetes superiores angulados em $5^{\circ}$ para os incisivos centrais, $9^{\circ}$, para os laterais e $11^{\circ}$, para os caninos.

Em 2000, Cuoghi et al. desenvolveram um estudo para estabelecer parâmetros radiográficos para a inclinação vestibulolingual e mesiodistal dos incisivos permanentes superiores durante a dentadura mista. Compararam-se 3 grupos de 20 telerradiografias em norma lateral e 20 ortopantomografias de crianças com idade de 7 a 12 anos, com uma oclusão normal. O grupo 1 apresentava apenas um incisivo central permanente irrompido, o grupo 2 apresentava ambos os centrais e os laterais permanentes e o grupo 3 possuía os incisivos centrais, laterais e os caninos permanentes irrompidos. A inclinação axial mesiodistal foi mensurada na radiografia ortopantomográfica, por meio do ângulo formado entre o longo eixo dentário e a linha que passava pelos pontos mais inferiores da cavidade orbitária. Os valores médios das inclinações vestibulolinguais, do grau de protrusão e das 
inclinações mesiodistais dos incisivos centrais e laterais no grupo 1, 2 e 3 foram, respectivamente, $112^{\circ}, 1,2 \mathrm{~mm}, 90,4^{\circ}$ e $91,7^{\circ}, 112^{\circ}, \quad 2,6 \mathrm{~mm}, 89,5^{\circ}$ e $96,8^{\circ}$ e $114^{\circ}$, $2,7 \mathrm{~mm}, 87,4^{\circ}$ e $92,6^{\circ}$. A quantidade de inclinação $v$ estibulolingual foi semelhante em todos os grupos, tendo sido a média dos valores da protrusão dentária estatisticamente significante a $5 \%$ quando se comparou o grupo 1 ao 2 e 3 . Os valores médios das inclinações mesiodistais foram estatisticamente significantes a $5 \%$ para os incisivos centrais entre o grupo 1 e 3 e a $1 \%$, para os laterais entre os grupos 1 e 2, 2 e 3.

No mesmo ano, Tsai (2000) realizou um estudo para observar o processo de erupção dos segundos molares superiores e inferiores por meio de 238 radiografias panorâmicas. Em cada uma dessas radiografias, o autor avaliou a inclinação axial mesiodistal, o padrão de erupção dos segundos molares e outros fatores. Avaliandose os resultados obtidos, concluiu-se que a inclinação axial dos segundos molares inferiores manteve-se quase constante e os superiores sofreram uma verticalização gradual considerando desde o estágio no qual a coroa apresentava-se calcificada até o estágio em que o comprimento radicular igualava-se ao tamanho da coroa dentária.

O correto posicionamento mesiodistal dos longos eixos dentários contribui sobremaneira para alcançar o equilíbrio da oclusão e do sistema estomatognático, fornecendo um perfeito alinhamento dos dentes em suas bases ósseas e uma manutenção da estabilidade dos resultados obtidos pelo tratamento ortodôntico. Um caso tratado ortodonticamente deveria apresentar, ao final do tratamento, a mesma inclinação axial encontrada na oclusão "normal". Com base nessas informações Almeida-Pedrin, Pinzan e Almeida (2001) avaliaram a inclinação axial mesiodistal dos dentes anterossuperiores e caninos inferiores ao início e término do tratamento ortodôntico, por meio das radiografias panorâmicas, de 40 jovens tratados ortodonticamente com a técnica "edgewise simplificada", sem a realização de extrações dentárias. Os autores compararam os valores obtidos entre si e com valores médios normais, propostos por Ursi (1989). Analisando os resultados, verificou-se que, com exceção do incisivo central superior direito, o tratamento ortodôntico alterou o posicionamento mesiodistal dos longos eixos dos dentes. Comparando-se os valores médios normais e as médias dos valores obtidos na fase inicial, as inclinações dos caninos superiores e inferior esquerdo, e dos incisivos centrais e laterais superiores direito não se mostravam concordes com as 
configurações anatômicas normais, sendo necessárias suas correções durante o tratamento ortodôntico. Os caninos inferiores e o incisivo lateral superior esquerdo apresentaram, ao final do tratamento, uma sobrecorreção de suas inclinações mesiodistais, sendo que o canino inferior direito encontrava-se, ao início do tratamento, bem posicionado, requerendo apenas a manutenção de sua inclinação inicial durante a terapêutica ortodôntica. Portanto, o profissional deveria atentar-se para as inclinações axiais mesiodistais dentárias, analisando-as clinicamente e, também, sempre que possível, por meio de radiografias panorâmicas iniciais e intermediárias, evitando, dessa maneira, uma sub ou sobrecorreções que provavelmente influenciariam na estabilidade dos casos. Os autores recomendaram também a avaliação das inclinações dentárias mesiodistais ao término do tratamento com o objetivo de controlar e avaliar as possíveis e tão frequentes recidivas ortodônticas. Deste modo, a angulação nos braquetes, como proposta na técnica edgewise simplificada, pode sobrecorrigir os dentes bem posicionados ao início do tratamento, resultando numa divergência radicular excessiva e contribuindo, negativamente, para a estabilidade dos casos tratados ortodonticamente sem extrações.

Brandão (2002) realizou uma pesquisa com o propósito de analisar, por meio das radiografias panorâmicas, as inclinações axiais mesiodistais dos dentes superiores e inferiores ao início, final e cinco anos após o término do tratamento ortodôntico em pacientes tratados com extrações dos quatro primeiros pré-molares, a fim de verificar se essas inclinações estavam concordes com o padrão médio normal proposto por Ursi (1989). Além disso, avaliaram se nos casos que indicavam recidiva de apinhamento após cinco anos de tratamento, avaliados pelo Índice de Irregularidade de Little, as inclinações axiais mesiodistais apresentavam valores muito discrepantes dos obtidos ao término do tratamento. Concluiu-se que as inclinações mesiodistais dos dentes na fase inicial do tratamento ortodôntico mostraram-se diferentes daquelas observadas em uma oclusão normal, em $85 \%$ dos dentes avaliados. Ao término do tratamento, $45 \%$ dos dentes analisados apresentavam valores próximos aos presentes em uma oclusão normal que foi descrita por Ursi (1989). Após cinco anos do término do tratamento, $55 \%$ dos dentes analisados apresentavam valores médios semelhantes aos valores presentes em uma oclusão normal. As alterações nas inclinações axiais mesiodistais ocorridas 
entre as fases final e pós tratamento não influenciaram na recidiva do apinhamento anteroinferior.

Santos et al. (2006) avaliaram, mediante radiografia panorâmica, a propensão de inclinação dos molares superiores para a distal durante o emprego do Pendex, aplicado no final do estágio da dentadura mista e na dentadura permanente. Foram tomadas duas radiografias panorâmicas, uma correspondente ao início do tratamento e outra aproximadamente 5 meses após, quando a relação dos molares encontrava-se sobrecorrigida. Concluíram que o aparelho Pendex mostrou-se eficiente tanto na quantidade como na velocidade de distalização dos molares superiores, favorecendo a correção da relação molar, mas às custas de inclinação da coroa para a distal.

Silva Filho et al. (2007) realizaram um estudo piloto avaliando a distalização de molares superiores com o aparelho Pendex unilateral através da radiografia panorâmica. $O$ estudo põe em pauta o efeito imediato da distalização unilateral de molares superiores. A amostra compôs-se de 3 pacientes na dentadura permanente madura, no estágio de adolescência, que apresentavam uma má oclusão de classe II, subdivisão. A metodologia baseou-se em radiografias panorâmicas inicial e pósdistalização para quantificar a inclinação axial mesiodistal dos molares superiores. Os resultados indicaram que os molares do lado esquerdo mantiveram sua inclinação mesiodistal inicial, sugerindo ancoragem, enquanto os molares do lado direito foram inclinados para distal, à semelhança do que ocorre com a distalização simétrica dos molares superiores, obtida com o aparelho Pendex convencional. Os primeiros molares foram inclinados $11,5^{\circ}$, enquanto os segundos molares, $21^{\circ}$ para distal.

Petridis et al. (2010) avaliaram as alterações na inclinação axial de dentes próximos a espaços edêntulos na região posterior. Para isso, foram utilizados modelos de estudo e radiografias panorâmicas. Os resultados mostraram que os dentes avaliados apresentaram uma inclinação para a distal com o passar do tempo após a perda do dente adjacente.

Martinelli et al. (2010) realizaram um estudo em que avaliaram as alterações normais da inclinação axial dos primeiros molares superiores em adolescentes com má oclusão esquelética de Classe II não tratada. As variáveis foram calculadas nas idades de 9, 12, 14 e 16 anos e não revelaram dimorfismo sexual. Os primeiros molares superiores apresentaram as coroas mais inclinadas para distal aos 9 anos 
idade com uma tendência a verticalizar gradualmente até 16 anos de idade. A tendência natural de verticalização foi, estatisticamente, maior no estágio entre $9 \mathrm{e}$ 12 anos do que no estágio entre 12 e 14 anos.

Cuoghi et al. (2010) compararam as inclinações mesiodistais de caninos, prémolares e molares inferiores com os valores médios normais. Os voluntários foram divididos em dois grupos, sendo o grupo I composto por 20 radiografias panorâmicas de indivíduos com ausência dos terceiros molares inferiores, e grupo II, formado por 20 radiografias de indivíduos com terceiros molares inferiores presentes. Os dois grupos, quando comparados, apresentaram valores semelhantes para a inclinação axial mesiodistal dos caninos, pré-molares e molares inferiores $(P<0,05)$, indicando que não houve influência dos terceiros molares. 

$3 P_{\text {roposição }}$ 



\section{PROPOSIÇÃO}

O propósito desta pesquisa consistiu em avaliar, por meio de radiografias panorâmicas, o comportamento longitudinal da inclinação axial mesiodistal dos primeiros e segundos molares superiores de pacientes submetidos ao tratamento distalizador da má oclusão de Classe II, corrigida com o aparelho Pendulum, seguido de aparelhagem ortodôntica fixa, nos períodos de tratamento e 5 anos pós tratamento e comparar com uma amostra de oclusão normal (1989). 

4 Materiale

Métodos 



\section{MATERIAL E MÉTODOS}

\subsection{Material}

\subsubsection{Amostra}

Para o presente estudo longitudinal e prospectivo, utilizou-se uma amostra composta vinte indivíduos, de ambos os gêneros (14 do gênero feminino, e 6 do masculino) com idade inicial média de 14,27 \pm 1,62 anos (Tabela 1), leucodermas, brasileiros, naturais da cidade de Bauru, Estado de São Paulo. Com um total de 60 radiografias panorâmicas, obtidas nas fases inicial (T1), final (T2) e cinco anos póstratamento (T3). Os pacientes foram selecionados a partir de uma amostra submetida ao tratamento distalizador com o aparelho Pendulum seguido de aparelhagem ortodôntica fixa, tratados por dois alunos do curso de pós-graduação, strictu sensu, encontrando-se a mesma em controle na Disciplina de Ortodontia da Faculdade de Odontologia de Bauru /USP.

Tabela 1- Médias, desvios-padrão, valor mínimo e máximo das idades inicial (T1), final (T2), pós-tratamento (T3), tempo de tratamento (T1-T2) e tempo pós-tratamento (T2-T3) do grupo Pendulum.

\begin{tabular}{c|c|c|c|c}
\hline Fase/Período & Idade Média & Idade Mínima & Idade Máxima & D.P. \\
\hline Idade Inicial & 14,27 & 11,35 & 17,02 & 1,62 \\
\hline Idade Final & 18,59 & 15,12 & 21,86 & 1,82 \\
\hline Idade Pós-Tratamento & 23,77 & 21,02 & 28,05 & 2,04 \\
\hline Tempo de Tratamento & 4,36 & 3,12 & 6,71 & 0,79 \\
\hline Tempo Pós-Tratamento & 5,18 & 2,84 & 7,32 & 1,14 \\
\hline
\end{tabular}

Vale ressaltar que, durante a seleção da amostra, não foi incluído nenhum critério de avaliação esquelética, somente verificou-se, ao início do tratamento, uma relação de molares e de caninos de Classe II nos modelos de estudo. Considerandose o tipo de má oclusão, 19 pacientes apresentavam, no início do tratamento, Classe II, divisão 1 (Figura 1) e 1 paciente, Classe II, divisão 2. Em relação à severidade da 
discrepância anteroposterior, 13 pacientes eram portadores de Classe II completa e 7, de 1/2 Classe II de Andrews (ANDREWS, 1975). Os pacientes apresentavam todos os dentes permanentes irrompidos, exceto os terceiros molares.

A relação molar foi corrigida por meio do uso do aparelho Pendulum, para distalização dos molares superiores, seguindo-se de instalação do aparelho ortodôntico fixo, pela mecânica Edgewise. A metodologia de tratamento desses pacientes foi previamente estabelecida por Fuziy (2001) e posteriormente por Angelieri (2002). Foi realizado um controle destes pacientes em média 5,18 anos após o término do tratamento ortodôntico. Ao início do tratamento ortodôntico (T1) 19 pacientes apresentavam os terceiros molares superiores presentes, porém não irrompidos. Ao final do tratamento (T2) somente 1 paciente necessitou a extração dos terceiros molares superiores. E na fase T3 mais 4 pacientes precisaram ter os seus terceiros molares superiores extraídos.

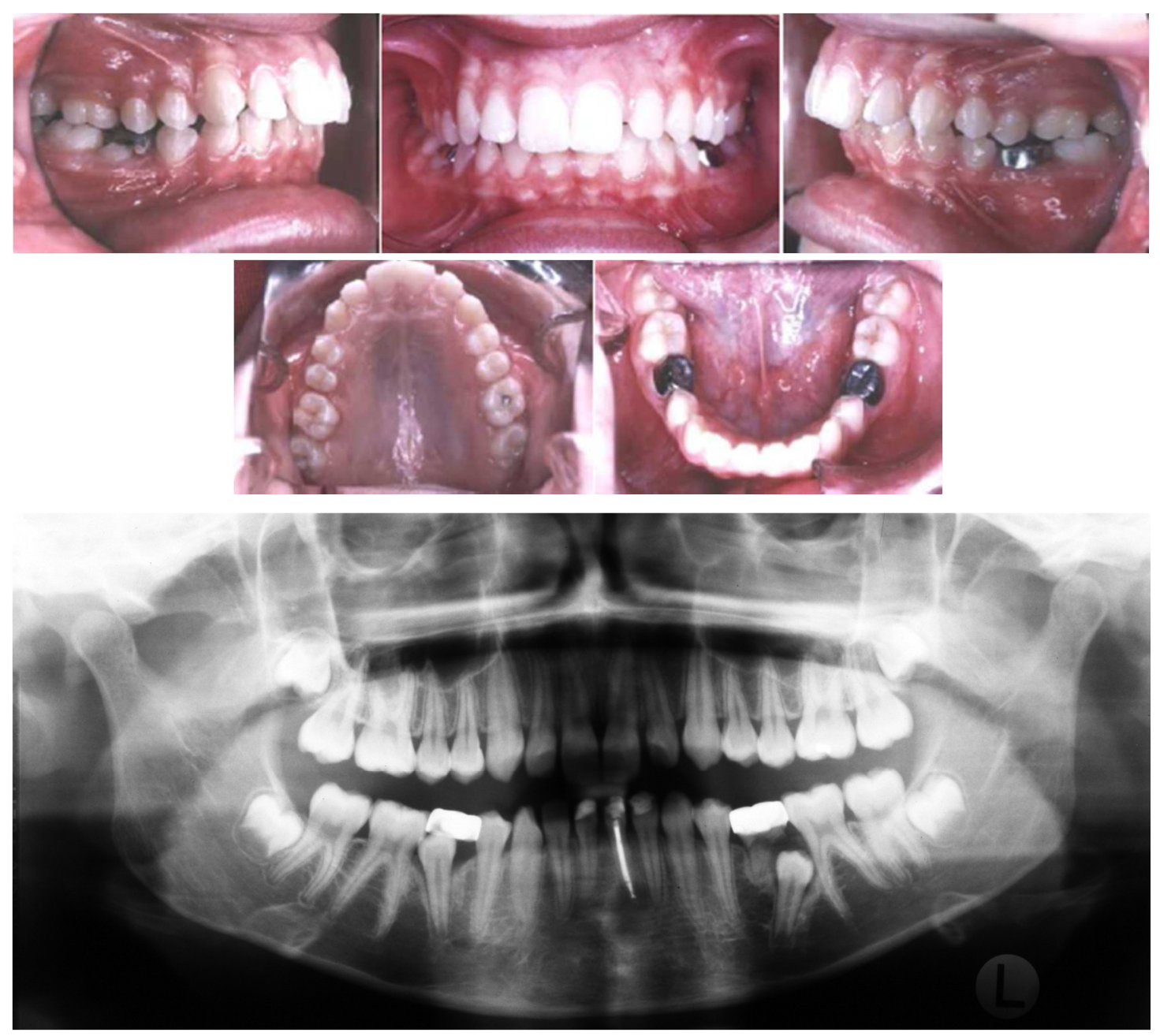

Figura 1: Fotografias intrabucais e radiografia panorâmica de uma paciente Classe II, divisão 1, antes do tratamento ortodôntico 
Como Grupo Controle, utilizou-se os valores angulares médios de molares superiores obtidos por Ursi (1989), sendo que essa obtenção partiu de radiografias panorâmicas de indivíduos apresentando idades entre 12 e 17 anos. Para fazer parte desta amostra, o autor selecionou, clinicamente, somente pacientes não tratados com oclusão normal, ou seja, com todos os dentes presentes (exceto os terceiros molares), relação molar e caninos de Classe I, máximo overbite de $3 \mathrm{~mm}$ e máximo overjet de $1 \mathrm{~mm}$. Foi obtida somente uma radiografia panorâmica de cada paciente, se tratando, portanto de uma amostra de caráter transversal.

\subsection{Métodos}

\subsubsection{Tratamento Ortodôntico}

Os pacientes receberam como mecanismos distalizadores dos molares superiores o aparelho Pendulum de Hilgers e, posteriormente, foi instalado um aparelho fixo para complementação do tratamento ortodôntico. A confecção do aparelho Pendulum se deu de acordo com Hilgers (1992) e envolveu duas fases, uma laboratorial e outra, clínica.

O aparelho Pendulum determina um sistema de força distalizadora de 250 gramas por lado, aplicada sobre os molares superiores com forças recíprocas correspondentes, atuando sobre os pré-molares, caninos e incisivos (Figura 2). Seu uso durou um período médio de $5,85 \pm 1,82$ meses até a obtenção de uma relação molar normal com aproximadamente $2 \mathrm{~mm}$ de sobrecorreção.

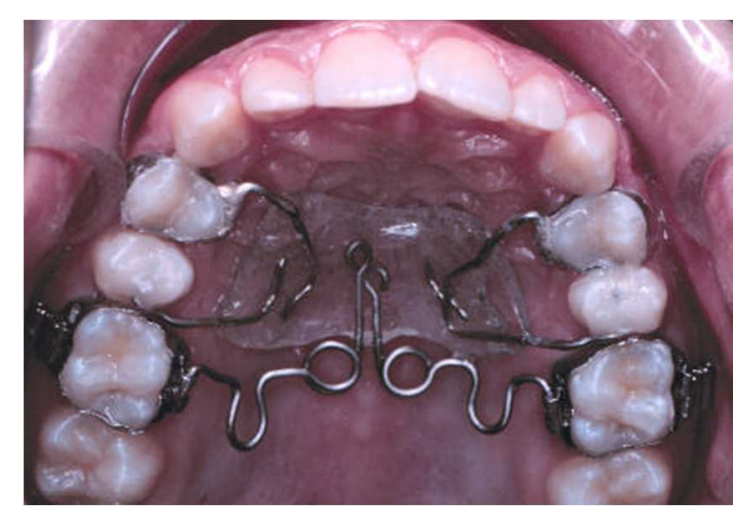

Figura 2: Aparelho Pendulum instalado 
No mesmo dia da remoção do aparelho Pendulum, foi posicionado um Botão de Nance com a finalidade de conter a tendência à recidiva dos molares distalizados, sendo que, no período decorrido da remoção e instalação, empregouse, como contenção, um botão de resina acrílica confeccionado individualmente na própria cavidade bucal do paciente. $\mathrm{O}$ aparelho construído em laboratório foi adaptado, do fio que emerge do botão de acrílico, no lado palatino ao tubo lingual dos primeiros molares superiores, anteriormente utilizado para inserção das molas distalizadoras do aparelho Pendulum.

Além disso, adicionou-se um aparelho extrabucal (AEB), tração cervical (KHG) com os braços externos levantados em 15\%, com intensidade de 400 a 500 gramas de força da cada lado, somente para uso noturno, de maneira a cooperar na manutenção do espaço obtido na distalização e proporcionar a verticalização dos molares (CARANO; TESTA; SICILIANI, 1996; CHAQUES-ASENSI; KALRA, 2001; HAYDAR; UNER, 2000; MANDURINO; BALDUCCI, 2001; PIERINGER; DROSCHL; PERMANN, 1997).

Após trinta dias, seguiu-se a montagem do aparelho ortodôntico fixo préajustado com ranhura 0,022"x 0,028", iniciando-se a sequência convencional de fios para alinhamento e nivelamento até 0 arco retangular $0,019 " x 0,025$ ", para a realização da retração dos pré-molares e caninos superiores um a um, quando esta não ocorreu espontaneamente devido à ação das fibras transeptais. Durante a retração anterossuperior, removeu-se o botão palatino de Nance, e, além do reforço de ancoragem representado pelo aparelho extrabucal de uso noturno, utilizaram-se elásticos de Classe II, de 1/4 de polegada, para uso de 12 a 20h/dia. Fechados os espaços, procedeu-se à finalização e intercuspidação dos casos. $O$ tempo médio de tratamento foi de 4,36 $\pm 0,79$ anos. Após a remoção do aparelho ortodôntico fixo, instalou-se a placa de Hawley superior e o $3 \times 3$ inferior para a contenção (Figura 3). 

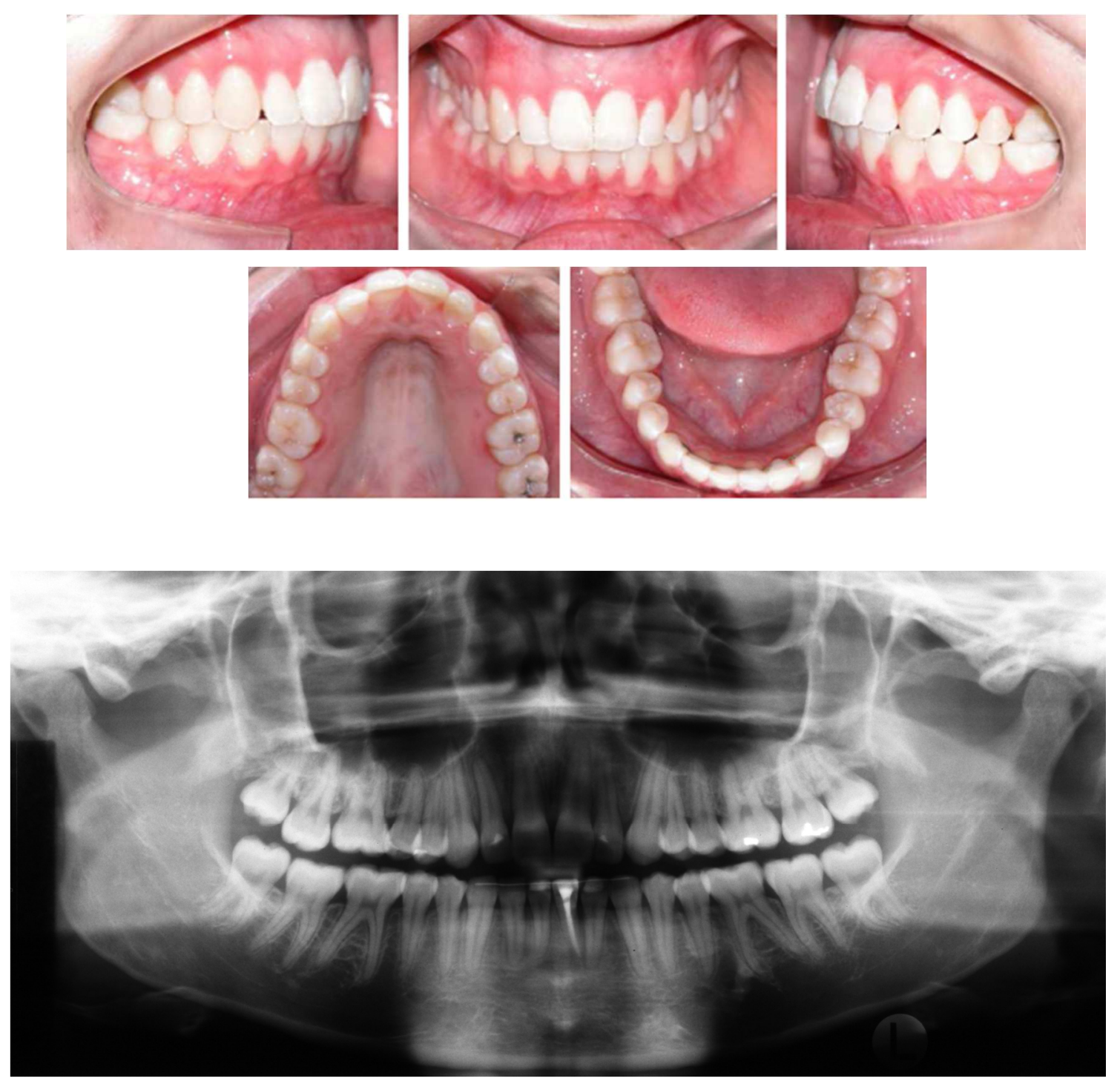

Figura 3: Fotografias intrabucais e radiografia panorâmica da paciente ilustrada na figura 1, após o término do tratamento ortodôntico

Realizou-se o controle do tratamento em média 5 anos após a término do mesmo, sendo a média da amostra avaliada de 5,18 $\pm 1,14$ anos (Tabela 1). Após a avaliação clínica dos pacientes, procedeu-se à realização de uma completa documentação incluindo radiografias (panorâmica e telerradiografia), modelos de estudo e fotografias extra e intrabucais (Figura 4). 

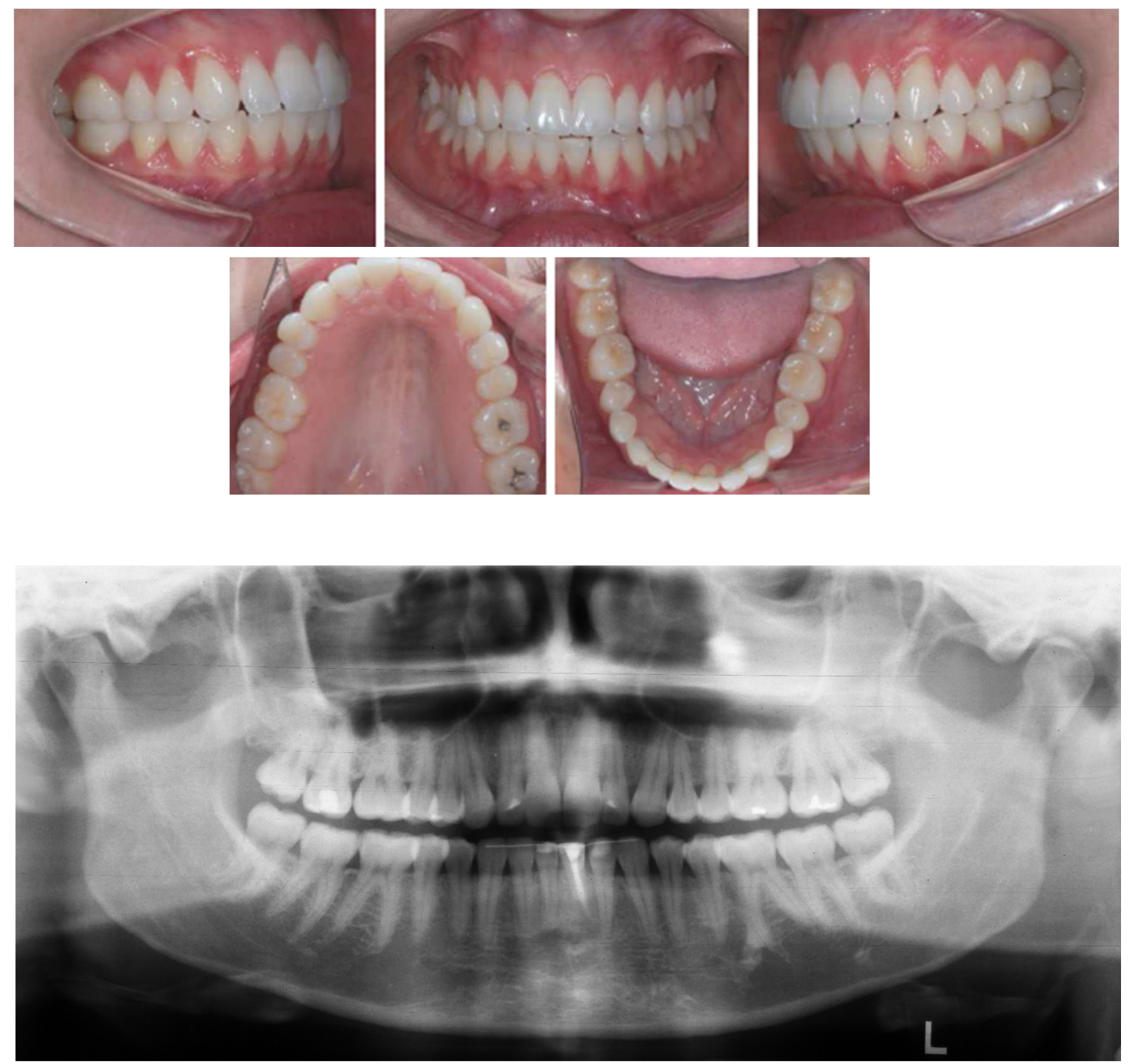

Figura 4: Fotografias intrabucais e radiografia panorâmica da paciente ilustrada na figura 1, cinco anos após o tratamento

\subsubsection{Método Radiográfico}

Para a realização deste estudo, utilizaram-se três radiografias panorâmicas de cada paciente, consideradas nos três tempos, T1 (inicial), T2 (final) e T3 (cinco anos pós-tratamento).

As radiografias foram obtidas com o paciente posicionado com plano oclusal paralelo e o plano sagital mediano perpendicular, ambos ao solo, estando os dentes desocluídos, por meio de uma espátula abaixadora de língua interposta na região anterior. 


\subsubsection{Elaboração do traçado}

Para a realização do traçado das radiografias panorâmicas, adaptou-se em cada radiografia uma folha de papel acetato "Ultraphan" de $0,07 \mathrm{~mm}$ de espessura, medindo $15 \mathrm{~cm}$ de largura por $21 \mathrm{~cm}$ de comprimento. Para facilitar a visualização e evidenciação das estruturas anatômicas necessárias para essa pesquisa, os traçados foram realizados em uma sala obscurecida sobre um negatoscópio e uma moldura confeccionada de cartolina preta foi posicionada com o intuito de eliminar focos laterais de luz, facilitando a visualização das estruturas anatômicas.

O traçado foi realizado em 3 fases:

1) Delimitação das estruturas dentoesqueléticas

2) Demarcação dos pontos de referência

3) Traçado das linhas de referência horizontais e verticais

\subsubsection{Delimitação das estruturas dentoesqueléticas}

O traçado constituiu-se dos seguintes reparos anatômicos (Figura 5):

a)-limites inferiores das cavidades orbitárias;

b)-contorno externo da imagem da mandíbula;

d)-contorno externo das coroas e raízes dos dentes permanentes superiores;

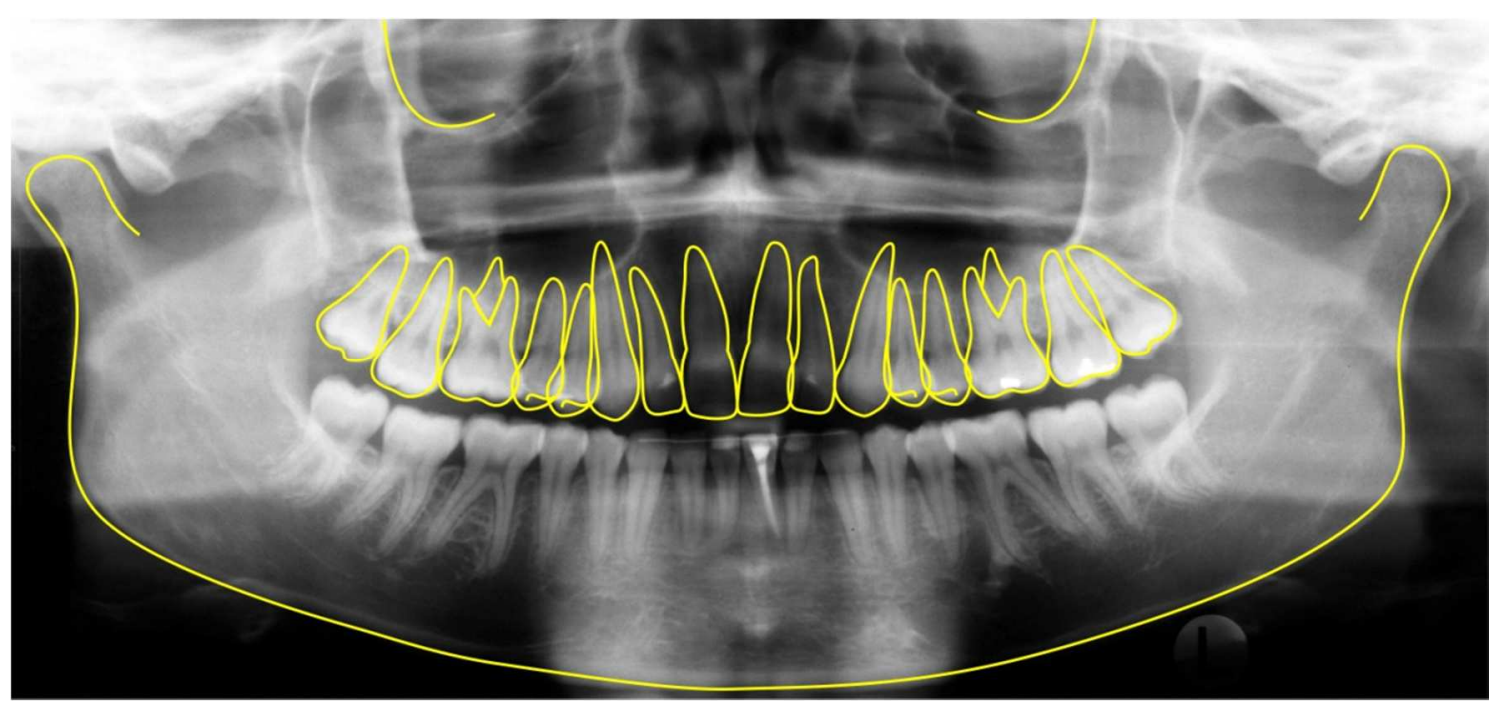

Figura 5: Delimitação das estruturas dentoesqueléticas 


\subsubsection{2.- Demarcação dos pontos de referência}

Os pontos de referência foram demarcados segundo Tavano et al. (1989) (Figura 6):

-Ord (orbital direito) ponto mais inferior da cavidade orbitária direita;

-Ore (orbital esquerdo) ponto mais inferior da cavidade orbitária esquerda;

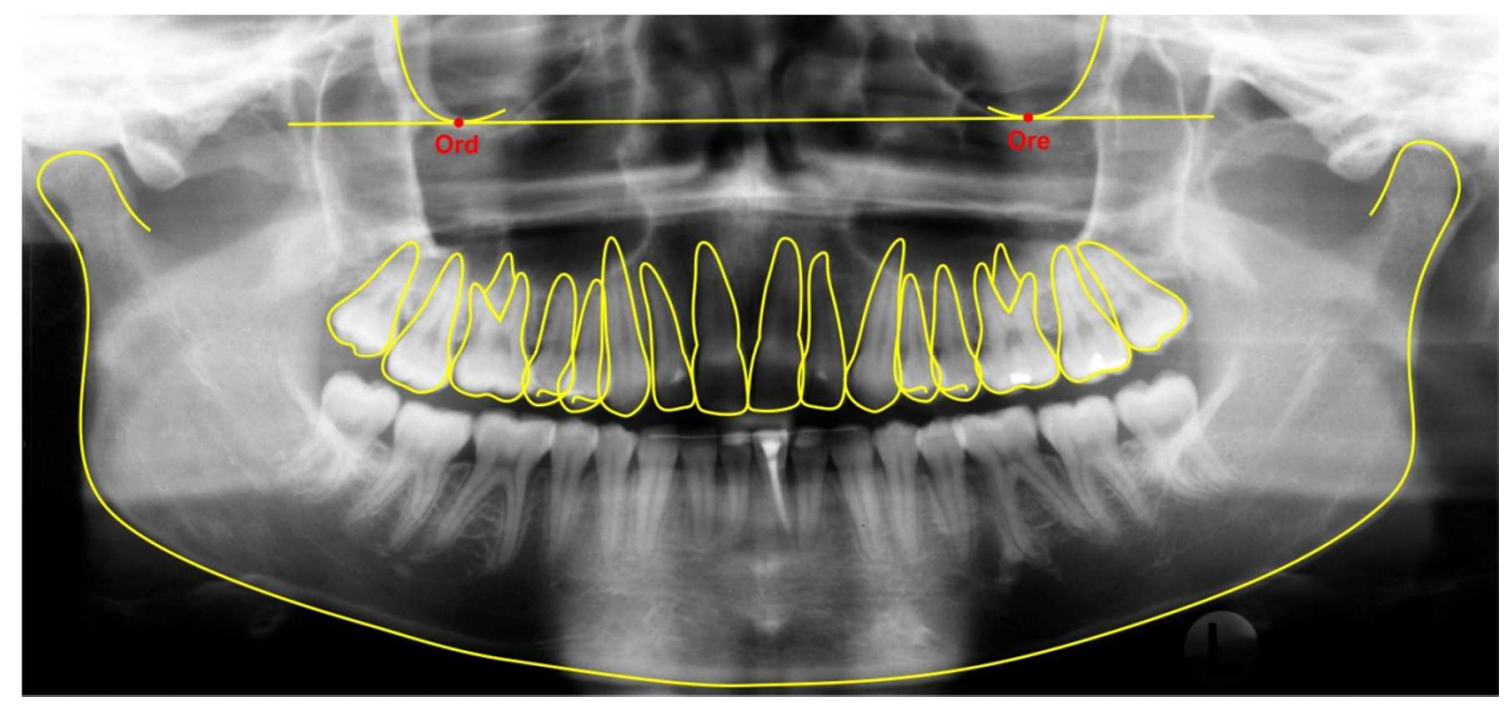

Figura 6: Demarcação dos pontos de referência

\subsubsection{Demarcação da Linha de Referência e dos Longos Eixos Dentários para Obtenção dos Ângulos}

A linha interorbital (IO) foi a linha de referência utilizada para realização das medições angulares dos dentes superiores nas radiografias panorâmicas, que segundo Tavano et al. (1989), deve passar pelos pontos orbital direito e orbital esquerdo.

- Linha interorbital - IO: linha que passa por Ord e Ore (Figura 7).

- Longo eixo dos molares superiores:

- Dentes trirradiculares ( $1^{\text {os }}$ e $2^{\text {os }}$ molares superiores): determinados pela imagem do longo eixo do canal radicular da raiz palatina sem considerar nenhum ponto de referência na coroa dentária (URSI, 1989) (Figura 7).

A intersecção dos longos eixos dentários com a linha de referência interorbitária permitiu a obtenção dos seguintes ângulos (Figura 8): 
- Â16 e Â26 - ângulo formado pela intersecção da linha do longo eixo dos $1^{\text {os }}$ molares superiores, direito e esquerdo, respectivamente, com a linha interorbitária.

- Â17 e Â27 - ângulo formado pela intersecção da linha do longo eixo dos $2^{\text {os }}$ molares superiores, direito e esquerdo, respectivamente, com a linha interorbitária.

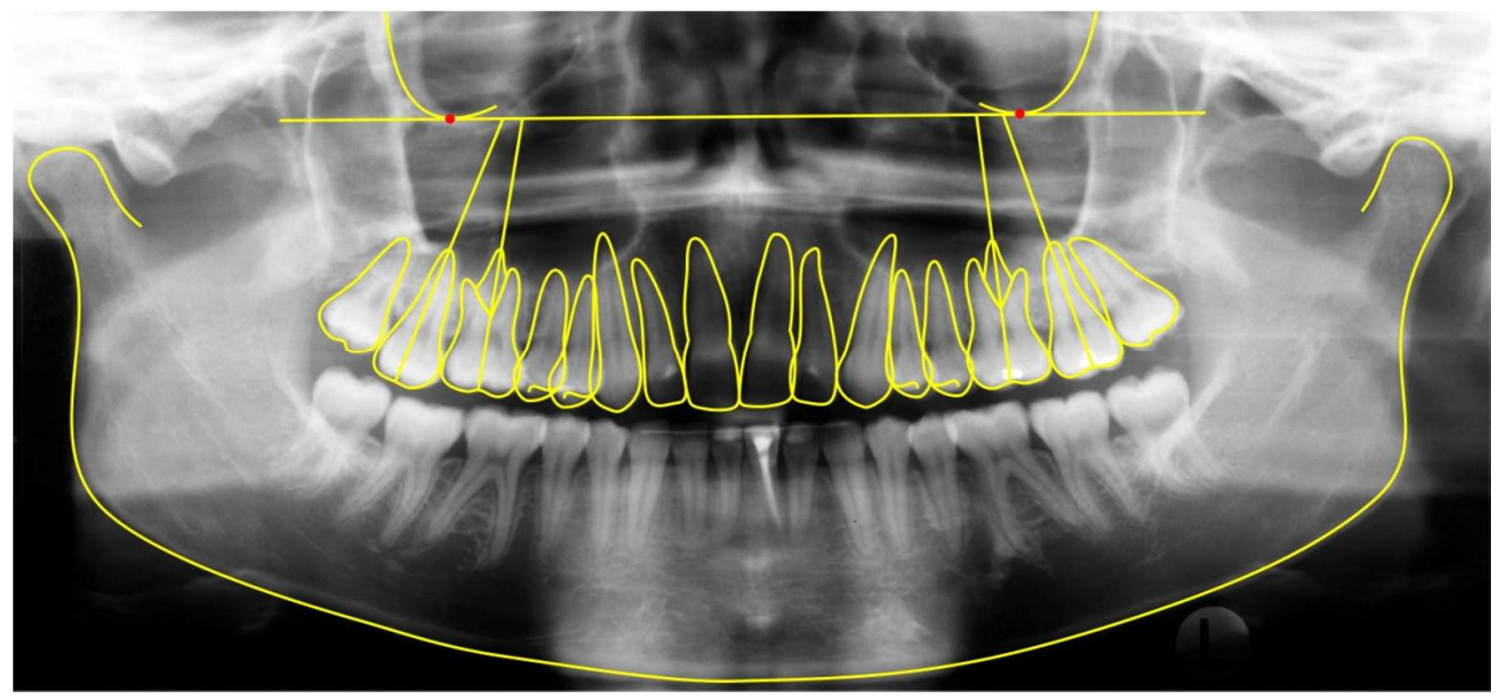

Figura 7: Demarcação da linha de referência e longo eixo dentário

\subsubsection{4- Mensuração dos ângulos}

Demarcados os pontos e as linhas, procedeu-se à mensuração dos ângulos formados pelos longos eixos dos dentes e a linha de referência utilizada para 0 arco superior (Figura 8).

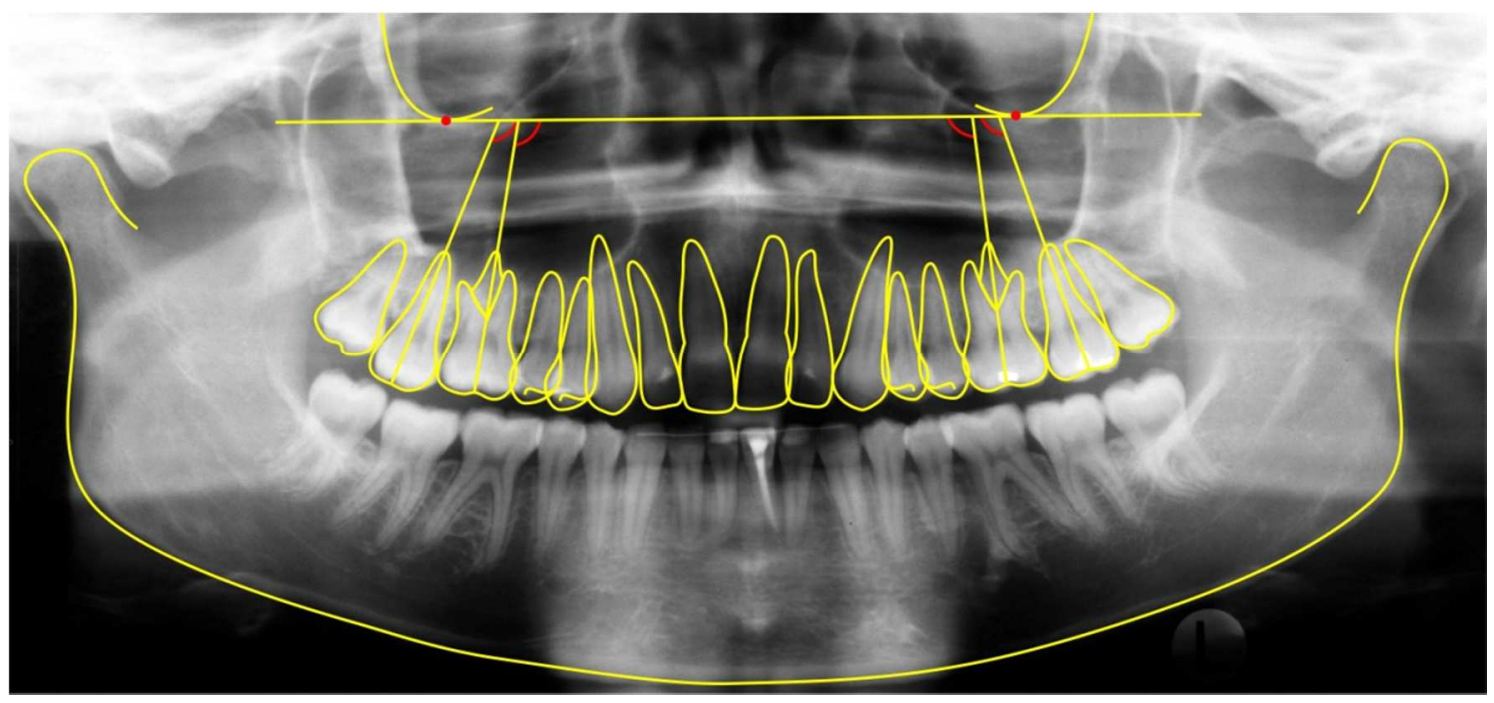

Figura 8: Mensuração dos ângulos 


\subsubsection{Análise Estatística}

\subsubsection{Erro do método}

O erro intraexaminador foi avaliado a partir da realização de novas medidas das variáveis estudadas nas fases inicial, final e cinco anos pós-tratamento de 6 pacientes da amostra, selecionados aleatoriamente. A primeira e a segunda medição foram realizadas com intervalo de tempo de um mês, obtendo-se, assim, duas medidas para as mesmas variáveis, embora em tempos diferentes. Para análise do erro casual, empregou-se a fórmula proposta por Dahlberg (1940), ( $\mathrm{Se}^{2}=$ $\Sigma \mathrm{d}^{2} / 2 \mathrm{n}$ ), aplicada para estimar a ordem de grandeza dos erros casuais, em que $\mathrm{Se}^{2}$ é o erro variável e $d$ a diferença entre as duas determinações da mesma variável e $n$ é o número das duas medidas. O erro sistemático se manifesta quando o examinador altera, inconscientemente, a técnica de mensuração com o passar do tempo. Para avaliação deste erro, foi realizado o teste t pareado sobre as medidas das variáveis (HOUSTON, 1983).

\subsubsection{Estatística}

O cálculo do tamanho da amostra para a diferença de duas médias foi realizado considerando o poder do teste de $80 \%$ e o coeficiente de confiança de $95 \%$. Os valores referentes à média e ao desvio padrão da variável avaliada em longo tempo pós-tratamento, bem como a estimativa da mínima diferença a detectar, necessários para realizar o cálculo amostral foram retirados dos resultados desta pesquisa.

Os valores obtidos para as variáveis estudadas foram dispostos em quadros do programa Excel e encaminhados para a análise estatística, para que as alterações decorrentes das fases inicial, final e cinco anos pós-tratamento fossem avaliadas.

Empregou-se a estatística descritiva das idades inicial, final e cinco anos póstratamento e para o período de tratamento (T1-T2) e período pós-tratamento (T2T3). Realizou-se também a estatística descritiva (média, desvio padrão e número) das variáveis estudadas nas fases inicial (T1), final (T2) e cinco anos pós-tratamento (T3), e as diferenças entre as fases inicial e final (T2-T1), caracterizando a correção 
do tratamento, e entre as fases final e cinco anos pós-tratamento (T3-T2), caracterizando a alteração durante o período pós-tratamento.

Para avaliação das alterações das variáveis entre as fases estudadas, foi utilizado o teste ANOVA dependente para medidas repetidas (repeated measures ANOVA), e na presença de um resultado significante, o teste de Tukey foi aplicado subsequentemente.

Realizou-se a comparação entre os valores das inclinações axiais mesiodistais dentárias obtidas nas fases inicial, final e cinco anos pós-tratamento e os valores médios normais propostos por Ursi (1989), utilizando-se, para isso, o teste "t" de Student para amostras independentes, ao nível de significância de $5 \%$.

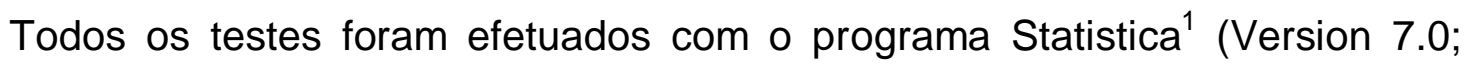
StatSoft Inc., Tulsa, OK, USA), adotando-se um nível de significância de 5\%.

${ }^{1}$ Statistica for Windows - Release 7.0 - Copyright StatSoft, Inc. 2001. 



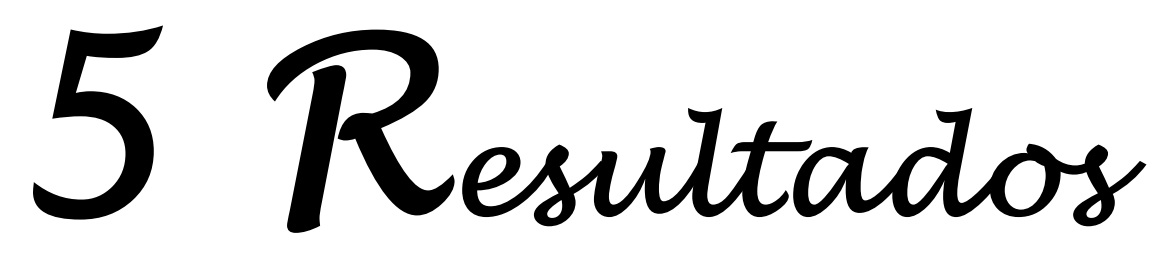





\section{RESULTADOS}

A apresentação dos resultados encontra-se organizada em tabelas.

O cálculo amostral foi realizado e revelou que o número da amostra está adequado para este estudo (Tabela 2).

Efetuou-se a análise da normalidade das variáveis, pelo teste estatístico Kolmogorov-Smirnov, que é premissa para utilizar a análise de variância. As variáveis apresentaram distribuição normal segundo o teste de Kolmogorov-Smirnov. Previamente aos resultados específicos da pesquisa, a Tabela 3 apresenta a avaliação dos erros sistemáticos e casuais, por meio do teste t pareado e da fórmula de Dahlberg (1940) aplicados a todas as variáveis estudadas.

Os resultados da análise estatística descritiva (média, desvio padrão, mínimo, máximo e número) das inclinações axiais mesiodistais das variáveis primeiro molar direito (16), primeiro molar esquerdo (26), segundo molar direito (17) e segundo molar esquerdo (27), em todas as fases (T1, T2 e T3) e períodos (T2-1 e T3-2) avaliados, encontram-se nas Tabelas de 4 a 7 . Os valores das inclinações axiais mediodistais dentárias dos dentes avaliados de cada paciente localizam-se no apêndice 2.

A Tabela 8 demonstra os resultados da análise de variância (ANOVA) para medidas repetidas e teste de Tukey, quando necessário, para todas as variáveis entre os tempos inicial, final e cinco anos pós-tratamento.

Os resultados das comparações realizadas entre os valores obtidos na fase inicial (T1), final (T2), cinco anos pós-tratamento (T3) com os valores médios normais obtidos por Ursi (1989) foram organizados nas Tabelas 9, 10 e 11, respectivamente. A Tabela 12 apresenta os valores médios normais das inclinações axiais mesiodistais, os valores na fase inicial (T1), final (T2), e cinco anos póstratamento (T3), demonstrando os valores que apresentaram diferença estatisticamente significante quando comparados aos valores médios normais. 
Tabela 2. Resultado para o cálculo do tamanho da amostra para diferença entre duas médias e um poder do teste de $80 \%$.

\section{Cálculo do tamanho da amostra para diferença entre duas médias}

\begin{tabular}{l|l}
\hline Estimativa do desvio padrão & 4,91 \\
\hline Mínima diferença a ser detectada & 4,5 \\
\hline$\alpha$ (erro tipo I) & $5 \%$ \\
\hline$\beta$ (Poder do teste) & $20 \%$ \\
\hline $\mathrm{N}$ & 20 \\
\hline
\end{tabular}

Tabela 3. Resultados do teste $t$ pareado e da fórmula de Dahlberg (1940), aplicados às variáveis 16, 26, 17 e 27, para estimativa dos erros sistemáticos e casuais, respectivamente $(\mathrm{N}=20)$.

\begin{tabular}{c|c|c|c|c|c|c}
\hline \multirow{2}{*}{ Variáveis } & \multicolumn{2}{|c}{$\mathbf{1}^{\text {a. Medição }}$} & \multicolumn{2}{c|}{ 2. Medição $^{\text {P }}$} & Dahlberg \\
\cline { 2 - 5 } & Média & DP & Média & DP & & \\
\hline $\mathbf{1 6}$ & 97,50 & 3,82 & 97,33 & 3,83 & 0,749 & 1,50 \\
\hline $\mathbf{2 6}$ & 97,67 & 4,30 & 98,00 & 3,45 & 0,518 & 1,49 \\
\hline $\mathbf{1 7}$ & 106,11 & 6,07 & 106,06 & 5,10 & 0,911 & 1,42 \\
\hline $\mathbf{2 7}$ & 106,39 & 5,36 & 105,83 & 5,12 & 0,066 & 0,91 \\
\hline
\end{tabular}

Tabela 4. Resultados da análise estatística descritiva para a variável do primeiro molar direito, em todas as fases e períodos avaliados.

\begin{tabular}{c|c|c|c|c|c}
\hline Variáveis & Média & Mínimo & Máximo & D.P. & $\mathbf{N}$ \\
\hline $\mathbf{1 6}$ T1 & 94,45 & 83,00 & 103,00 & 4,91 & 20 \\
\hline $\mathbf{1 6}$ T2 & 98,95 & 89,00 & 110,00 & 5,50 & 20 \\
\hline $\mathbf{1 6}$ T3 & 95,25 & 88,00 & 104,00 & 4,40 & 20 \\
\hline $\mathbf{1 6}$ T2-T1 & 4,50 & $-4,00$ & 17,00 & 6,10 & 20 \\
\hline $\mathbf{1 6}$ T3-T2 & $-3,70$ & $-15,00$ & 4,00 & 4,65 & 20 \\
\hline
\end{tabular}


Tabela 5. Resultados da análise estatística descritiva para a variável do primeiro molar esquerdo, em todas as fases e períodos avaliados.

\begin{tabular}{c|c|c|c|c|c}
\hline Variáveis & Média & Mínimo & Máximo & D.P. & $\mathbf{N}$ \\
\hline $\mathbf{2 6}$ T1 & 94,55 & 78,00 & 109,00 & 7,54 & 20 \\
\hline $\mathbf{2 6}$ T2 & 98,60 & 90,00 & 106,00 & 4,19 & 20 \\
\hline $\mathbf{2 6}$ T3 & 94,25 & 84,00 & 103,00 & 5,38 & 20 \\
\hline $\mathbf{2 6}$ T2-T1 & 4,05 & $-8,00$ & 18,00 & 6,55 & 20 \\
\hline $\mathbf{2 6}$ T3-T2 & $-4,35$ & $-14,00$ & 7,00 & 5,97 & 20 \\
\hline
\end{tabular}

Tabela 6. Resultados da análise estatística descritiva para a variável do segundo molar direito, em todas as fases e períodos avaliados.

\begin{tabular}{c|c|c|c|c|c}
\hline Variáveis & Média & Mínimo & Máximo & D.P. & $\mathbf{N}$ \\
\hline $\mathbf{1 7}$ T1 & 108,10 & 89,00 & 119,00 & 7,66 & 20 \\
\hline $\mathbf{1 7}$ T2 & 109,40 & 93,00 & 124,00 & 7,24 & 20 \\
\hline $\mathbf{1 7}$ T3 & 107,75 & 94,00 & 126,00 & 8,47 & 20 \\
\hline $\mathbf{1 7}$ T2-T1 & 1,30 & $-10,00$ & 22,00 & 8,04 & 20 \\
\hline $\mathbf{1 7}$ T3-T2 & $-1,65$ & $-15,00$ & 6,00 & 5,26 & 20 \\
\hline
\end{tabular}

Tabela 7. Resultados da análise estatística descritiva para a variável do segundo molar esquerdo, em todas as fases e períodos avaliados.

\begin{tabular}{c|c|c|c|c|c}
\hline Variáveis & Média & Mínimo & Máximo & D.P. & $\mathbf{N}$ \\
\hline $\mathbf{2 7}$ T1 & 106,80 & 80,00 & 121,00 & 8,56 & 20 \\
\hline $\mathbf{2 7}$ T2 & 109,25 & 89,00 & 124,00 & 7,35 & 20 \\
\hline $\mathbf{2 7}$ T3 & 106,10 & 85,00 & 125,00 & 9,49 & 20 \\
\hline 27 T2-T1 & 2,45 & $-9,00$ & 18,00 & 6,50 & 20 \\
\hline 27 T3-T2 & $-3,15$ & $-18,00$ & 5,00 & 5,71 & 20 \\
\hline
\end{tabular}


Tabela 8. Resultados da análise de variância (ANOVA) e teste de Tukey para as variáveis 16, 26, 17 e 27, entre os tempos inicial, final e cinco anos pós-tratamento (letras semelhantes significam que não há diferença estatisticamente significante).

\begin{tabular}{c|c|c|c|c|c|c|c|c}
\hline \multirow{2}{*}{ Variáveis } & \multicolumn{2}{|c|}{ T1 } & \multicolumn{2}{c|}{ T2 } & \multicolumn{2}{c|}{ T3 } & P & Sig. \\
\cline { 2 - 8 } & Média & D.P. & Média & DP & Média & D.P. & & \\
\hline $\mathbf{1 6}$ & $94,45^{\mathrm{a}}$ & 4,91 & $98,95^{\mathrm{b}}$ & 5,50 & $95,25^{\mathrm{a}}$ & 4,40 & 0,001866 & * \\
\hline $\mathbf{2 6}$ & $94,55^{\mathrm{a}}$ & 7,54 & $98,60^{\mathrm{b}}$ & 4,19 & $94,25^{\mathrm{a}}$ & 5,38 & 0,011745 & * \\
\hline $\mathbf{1 7}$ & 108,10 & 7,66 & 109,40 & 7,24 & 107,75 & 8,47 & 0,584236 & NS \\
\hline $\mathbf{2 7}$ & 106,80 & 8,56 & 109,25 & 7,35 & 106,10 & 9,49 & 0,109888 & NS \\
\hline
\end{tabular}

letras semelhantes significam que não há diferença estatisticamente significante

Tabela 9: Valores médios normais (padrão) e desvios-padrão das inclinações axiais mesiodistais de cada dente, médias (média T1) e desvios-padrão (DP T1) dos valores das inclinações axiais obtidas na fase inicial (T1) do tratamento, valor de " $\mathrm{t}$ " e níveis de probabilidade de significância (p).

\begin{tabular}{c|c|c|c|c|c|c}
\hline \multirow{2}{*}{ Variáveis } & \multicolumn{2}{|c}{ Valor Padrão } & \multicolumn{2}{c}{ Valor T1 } & \multicolumn{1}{c}{ T } \\
\cline { 2 - 7 } & Média & D.P. & Média & DP & T & P \\
\hline $\mathbf{1 6}$ & 94,50 & 6,69 & 94,45 & 4,91 & 0,021921 & 0,982678 \\
\hline $\mathbf{2 6}$ & 93,25 & 5,80 & 94,55 & 7,54 & $-0,43706$ & 0,665678 \\
\hline $\mathbf{1 7}$ & 111,37 & 8,76 & 108,10 & 7,66 & 0,982238 & 0,335035 \\
\hline $\mathbf{2 7}$ & 112,25 & 7,25 & 106,80 & 8,56 & 1,584048 & 0,125272 \\
\hline
\end{tabular}

Tabela 10: Valores médios normais (padrão) e desvios-padrão das inclinações axiais mesiodistais de cada dente, médias (média T2) e desvios-padrão (DP T2) dos valores das inclinações axiais obtidas na fase final (T2) do tratamento, valor de "t" e níveis de probabilidade de significância ( $p$ ).

\begin{tabular}{c|c|c|c|c|c|c}
\hline \multirow{2}{*}{ Variáveis } & \multicolumn{2}{|c}{ Valor Padrão } & \multicolumn{2}{c}{ Valor T2 } & \multicolumn{1}{c}{ T } \\
\cline { 2 - 7 } & Média & D.P. & Média & DP & T & P \\
\hline $\mathbf{1 6}$ & 94,50 & 6,69 & 98,95 & 5,50 & $-1,81924$ & 0,080411 \\
\hline $\mathbf{2 6}$ & 93,25 & 5,80 & 98,60 & 4,19 & $-2,73547$ & 0,011072 \\
\hline $\mathbf{1 7}$ & 111,37 & 8,76 & 109,40 & 7,24 & 0,614507 & 0,544221 \\
\hline $\mathbf{2 7}$ & 112,25 & 7,25 & 109,25 & 7,35 & 0,978955 & 0,336624 \\
\hline
\end{tabular}


Tabela 11: Valores médios normais (padrão) e desvios-padrão das inclinações axiais mesiodistais de cada dente, médias (média T3) e desvios-padrão (DP T3) dos valores das inclinações axiais obtidas cinco anos pós-tratamento (T3), valor de "t" e níveis de probabilidade de significância $(p)$.

\begin{tabular}{c|c|c|c|c|c|c}
\hline \multirow{2}{*}{ Variáveis } & \multicolumn{2}{|c|}{ Valor Padrão } & \multicolumn{2}{c|}{ Valor T3 } & \multicolumn{1}{c}{} \\
\cline { 2 - 7 } & Média & D.P. & Média & DP & t & P \\
\hline $\mathbf{1 6}$ & 94,50 & 6,69 & 95,25 & 4,40 & $-0,35012$ & 0,729069 \\
\hline $\mathbf{2 6}$ & 93,25 & 5,80 & 94,25 & 5,38 & $-0,43497$ & 0,667170 \\
\hline $\mathbf{1 7}$ & 111,37 & 8,76 & 107,75 & 8,47 & 1,013242 & 0,320282 \\
\hline $\mathbf{2 7}$ & 112,25 & 7,25 & 106,10 & 9,49 & 1,643933 & 0,112230 \\
\hline
\end{tabular}

Tabela 12: Valores médios normais das inclinações axiais mesiodistais de cada dente, médias dos valores obtidos na fase inicial (T1), final (T2) e cinco anos póstratamento (T3).

\begin{tabular}{c|c|c|c|c}
\hline Variáveis & Média & Média T1 & Média T2 & Média T3 \\
\hline $\mathbf{1 6}$ & 94,50 & 94,45 & 98,95 & 95,25 \\
\hline $\mathbf{2 6}$ & 93,25 & 94,55 & $98,60^{*}$ & 94,25 \\
\hline $\mathbf{1 7}$ & 111,37 & 108,10 & 109,40 & 107,75 \\
\hline $\mathbf{2 7}$ & 112,25 & 106,80 & 109,25 & 106,10 \\
\hline
\end{tabular}

* valores que apresentaram diferença estatisticamente significante quando comparados aos valores médios normais 



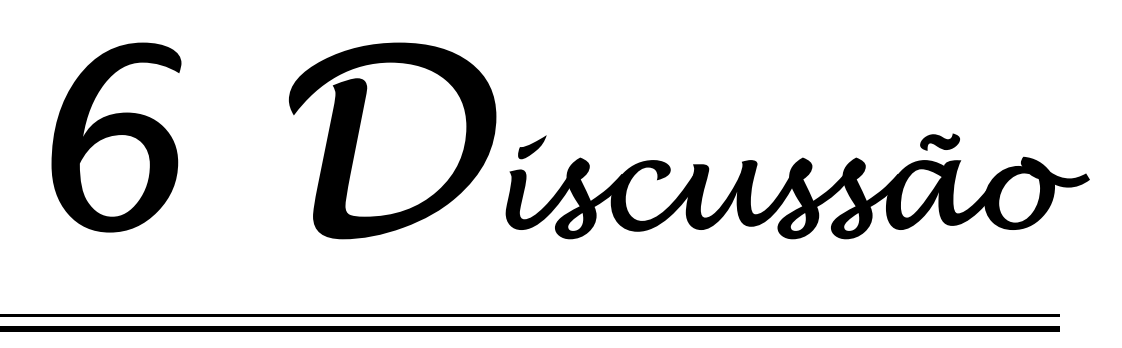





\section{DISCUSSÃO}

Com o intuito de proporcionar um melhor entendimento dos resultados obtidos e um maior discernimento sobre as variáveis envolvidas neste estudo, discutiu-se numa sequência estratificada, a amostra utilizada, a metodologia aplicada, sua precisão e os resultados obtidos.

\subsection{A amostra utilizada}

A amostra utilizada neste estudo constou de 60 radiografias panorâmicas de brasileiros de ambos os gêneros, tratados através da distalização dos molares superiores seguida do aparelho fixo. Um dos critérios mais importantes da seleção da amostra foi a presença inicial de má oclusão de Classe II, com a severidade de pelo menos meia Classe II (WHEELER . et al., 2002).

Esta amostra possui caráter prospectivo de maior poder avaliativo que os estudos retrospectivos (TULLOCH; MEDLAND; TUNCAY, 1990), já que minimiza as variações que podem ocorrer durante o tratamento ortodôntico. Além disso, o número de pacientes apresentado nesta amostra compreende uma quantidade, considerável em termos de valor estatístico sendo o mesmo utilizado em outros estudos (ANGELIERI et al., 2006; BYLOFF; DARENDELILER, 1997; BYLOFF et al., 1997; CHAQUES-ASENSI; KALRA, 2001; CLEMMER; HAYES, 1979; KLOCKE; NANDA; KAHL-NIEKE, 2002; TANER et al., 2003).

A representatividade de uma amostra é importante para que os dados coletados sejam extrapolados para a população, embora, o correto dimensionamento da amostra seja uma tarefa complexa (VALLADARES-NETO; DOMINGUES; CAPELLOZZA-FILHO, 2000) e, muitas vezes, independe da boa vontade do pesquisador. Evidentemente, amostras compostas por grandes números de pacientes são preferíveis, apesar de vários fatores influenciarem no tamanho das mesmas. Com o tempo, o número de pacientes de toda amostra tende invariavelmente a diminuir, seja por desistência do tratamento, mudança de cidade, falta de colaboração ou até mesmo pela recusa de o paciente realizar a documentação necessária, especialmente com relação aos controles após o 
tratamento (BONDEMARK et al., 2007). Desse modo, os estudos longitudinais, apesar de grande importância no contexto científico, apresentam algumas limitações quanto a dimensão da amostra. O tamanho da amostra necessário para a obtenção de resultados confiáveis se baseia no comportamento do parâmetro a ser avaliado, ou seja, quando se almeja estudar um efeito de grande expressão ou que sofre pequena variação é necessária uma amostra menor do que quando se estuda um parâmetro que sofre muita variação, caso em que há a necessidade de um maior número de observações para se verificar o efeito estudado (TULLOCH; MEDLAND; TUNCAY, 1990). O número de pacientes utilizado pode ser considerado suficiente para conferir confiabilidade aos resultados, levando-se em conta que outros trabalhos semelhantes empregaram amostras de tamanho compatível com 0 presente estudo (JANSON et al., 2004; LEHMAN; ROMULI; BAKKER, 1988; MILLS; MCCULLOCH, 2000; PANCHERZ, 1977). Convém ressaltar que a amostra encontra-se dentro dos limites preconizados por Houston, em 1983, o qual relata que, para a validade de qualquer estudo longitudinal, a amostra deve apresentar, no mínimo, 15 componentes. Além disso, foi realizado o cálculo do tamanho da amostra para diferença entre duas médias que mostrou que, para ser satisfatória, esta amostra deve apresentar pelo menos 20 pacientes. Para esse cálculo, é necessário um valor para estimativa do desvio padrão e um valor para mínima diferença a ser detectada. Foram utilizados como base os valores obtidos neste estudo. Portanto, a amostra utilizada neste estudo deve ser considerada satisfatória.

É importante destacar que os pacientes desta amostra apresentavam os segundos molares irrompidos. A maioria dos estudos pertinentes não dá importância para o estágio de erupção dos segundos molares superiores durante a distalização dos primeiros molares com distalizadores intrabucais, atribuindo pouca influência desses dentes na resposta dos primeiros molares sob influência do Pendulum ou Pendex (BUSSICK; MCNAMARA, 2000; BYLOFF; DARENDELILER, 1997; GHOSH; NANDA, 1996; JOSEPH; AUTCHART, 2000). Porém, o artigo de Kinzinger et al. (2004) estabelece que a condição de erupção dos segundos molares superiores influencia significativamente na distalização dos primeiros molares. O germe do segundo molar não irrompido funciona como fulcro para rotação do primeiro molar, durante a distalização com o aparelho Pendulum. O ponto de contato intraósseo do primeiro molar com o segundo molar não irrompido determina maior inclinação do 
primeiro molar para distal. O ponto de contato das coroas do primeiro e segundo molares reduz a inclinação axial do primeiro molar durante a distalização.

A respeito dos terceiros molares, alguns pacientes realizaram extrações dos mesmos durante o período pós-tratamento e outros não o possuíam ao início do tratamento. Os terceiros molares superiores irrompidos ou semi-irrompidos tendem a impedir a distalização dos primeiros e segundos molares durante o tratamento. Por esta razão, quando possível, indica-se a extração dos mesmos (GIANELLY, 1998; KINZINGER et al., 2004). Quando o germe do terceiro molar é removido, há um maior movimento de corpo dos molares para distal.

O período de controle de mais 5 anos após o tratamento é favorável para a observação do comportamento da inclinação axial mesiodistal das variáveis avaliadas. Segundo a metodologia empregada para a realização da revisão sistemática que versa sobre a estabilidade em longo prazo e satisfação do paciente, Bondemark et al. (2007) utilizaram como principal critério para seleção dos estudos o período de observação maior que 5 anos.

Visando a um estudo cientificamente satisfatório, o ideal seria comparar o grupo experimental a um grupo controle com características de má oclusão de Classe II não tratada, a fim de avaliar possíveis alterações dentoesqueléticas, apesar de a obtenção de um grupo controle com essas características e que não tenha sido submetido a tratamento ser extremamente difícil (DERMAUT; VAN DEN EYNDE; DE PAUW, 1992; PANCHERZ; FACKEL, 1990). Uma das razões para tamanha dificuldade é a necessidade de tratamento ortodôntico que a maioria destes pacientes apresenta, uma vez que esse tipo de má oclusão envolve problemas estéticos e funcionais. Além disso, as razões éticas, muito discutidas atualmente, tornam-se ainda mais difíceis a coletânea longitudinal desses dados, já que os pacientes seriam examinados apenas com o propósito de pesquisa (DERMAUT; VAN DEN EYNDE; DE PAUW, 1992). Martinelli et al. (2010) realizaram um estudo em que avaliaram as alterações normais da inclinação axial dos primeiros molares superiores em adolescentes com má oclusão esquelética de Classe II não tratada. As variáveis foram calculadas nas idades de 9, 12, 14 e 16 anos e não houve registro de dimorfismo sexual. Os primeiros molares superiores apresentaram as coroas mais inclinadas pra distal aos 9 anos idade com uma tendência a verticalizar gradualmente até 16 anos de idade. A tendência natural de verticalização foi 
estatisticamente maior no estágio entre 9 e 12 anos do que no estágio entre 12 e 14 anos.

A média de idade inicial, neste estudo, foi de 14,27, finalizando-se o tratamento aos 18,59 e com idade pós-tratamento de 23,77. Ou seja, ao término do tratamento, os pacientes encontravam-se em uma idade na qual a verticalização normal dos molares já havia ocorrido, sendo que o pico de crescimento acontece por volta dos 12 e 14 anos para meninas e meninos, respectivamente. Ressalta-se, portanto, que a terapia foi realizada após o surto de crescimento, e a avaliação das variáveis se deu quando o mesmo já estava no final desse processo. Portanto, a comparação do grupo experimental com um controle com características de má oclusão de Classe II não tratada torna-se pouco relevante para esta pesquisa.

Em busca de uma complementação para este estudo, a amostra foi comparada com os valores médios normais propostos por Ursi (1989), sendo que, de acordo com ele, a média de idade do grupo em que foram obtidos os valores médios normais varia de 12 a 17 anos. Convém lembrar que, para fazer parte desta amostra, o autor selecionou somente pacientes não tratados com oclusão normal, ou seja, com todos os dentes presentes, relação molar de Classe I, máximo overbite e overjet de $3 \mathrm{~mm}$ e $1 \mathrm{~mm}$, respectivamente. É importante ressaltar que a metodologia deste trabalho é a mesma utilizada no trabalho de Ursi.

\subsection{Metodologia}

\subsubsection{Radiografia panorâmica}

Para a realização dessa pesquisa, foi empregada a radiografia panorâmica como meio auxiliar para obter e mensurar as inclinações axiais mesiodistais dos molares superiores.

O principal responsável pelo desenvolvimento e aprimoramento das radiografias panorâmicas foi Paatero, que, em 1961, criou o primeiro ortopantomógrafo (PAATERO, 1948, 1954, 1961). A partir de então, a técnica radiográfica tornou-se fundamental e imprescindível como meio auxiliar de diagnóstico em todas as áreas da odontologia. Desde então, desenvolveram-se diversas pesquisas referentes à quantidade de radiação, às vantagens e indicações da técnica, às distorções das estruturas anatômicas e ao aperfeiçoamento dos 
aparelhos no sentido de melhorar a qualidade da imagem. Os principais motivos da difusão da técnica encontram-se relacionados à operacionalidade, à simplicidade de uso aliada ao posicionamento do paciente no aparelho, ao custo reduzido e a baixa exposição do paciente à radiação $X$, quando se analisa sua grande área de abrangência (BLACKMAN, 1960; CAPELLI, 1991; FRYKHOLM et al., 1977; GARDINER; MILLS, 1971; ISHIKAWA, 1968; KITE, 1962; PHILLIPS, 1967). Por esses motivos, a radiografia panorâmica constitui um dos itens essenciais na documentação ortodôntica ainda nos dias atuais (PECK et al., 2007).

Vários autores (ALMEIDA; BÓSCOLO; MONTEBELLO FILHO, 1995; ALPERN, 1984; BLACKMAN, 1956; BREZDEN; BROOKS, 1987; CUOGHI; SELLA; MENDONÇA, 2010; GILBERT, 1962; LUND; MANSON-HING, 1975; MCKEE et al., 2001; NELSEN; KUMPULA, 1952; PAATERO, 1954; RUSHTON; HORNER; WORTHINGTON, 1999) relataram a importância do correto posicionamento do paciente no aparelho durante a tomada radiográfica para diminuir as distorções e fornecer uma radiografia com boa qualidade da imagem e que pudesse ser utilizada como um instrumento confiável nas pesquisas odontológicas. Baseado nisso, e com intuito de melhorar o posicionamento do paciente e permitir o uso da radiografia panorâmica nas pesquisas odontológicas, Kane (1967) desenvolveu um cefalostato para o aparelho Panorex; Richardson, Langland e Sippy (1969) desenvolveram um cefalostato para ser utilizado no aparelho Ortopantomógrafo e Alpern (1979), para o aparelho Panelipse.

As radiografias panorâmicas foram consideradas um método de diagnóstico auxiliar indispensável na clínica odontológica, por demonstrar, em um único filme, a relação de toda a dentição, o osso alveolar, a articulação temporomandibular e as estruturas adjacentes (PHILLIPS, 1967).

A radiografia panorâmica é amplamente utilizada em diversos campos da odontologia para realizar exames dentários rotineiros (MITCHELL, 1963), permitindo um diagnóstico clínico correto, tanto em crianças quanto em adultos (BLACKMAN, 1960; CHILES; GORES, 1973).

Em ortodontia as radiografias panorâmicas também apresentam grande destaque porque auxiliam na determinação da inclinação axial mesiodistal dos dentes antes e após o tratamento ortodôntico (ALMEIDA-PEDRIN et al., 2006; BRANDÃO, 2002; CUOGHI; SELLA; MENDONÇA, 2010; FRYKHOLM et al., 1977; KANE, 1967; MCKEE et al., 2002; URSI et al., 1990) e do paralelismo radicular, 
principalmente nas áreas próximas às extrações (FRYKHOLM et al., 1977; GRABER, 1966; KANE, 1967; MCKEE et al., 2002).

Com relação às radiografias empregadas no estudo, convém salientar uma atenção especial à padronização, com o objetivo de obter radiografias com boa qualidade de imagem de modo a permitir um correto diagnóstico (ALPERN, 1984; GILBERT, 1962; LUND; MANSON-HING, 1975; NELSEN; KUMPULA, 1952; PAATERO, 1954; SAMAWI; BURKE, 1984), com mínimas distorções, visto que o posicionamento inadequado do paciente no aparelho compromete a qualidade da imagem, aumentando as distorções e prejudicando a interpretação da radiografia (ALMEIDA; BÓSCOLO; HAITER NETO, 1995; BREZDEN; BROOKS, 1987; CHRISTEN; SEGRETO, 1968; KITE, 1962; RICHARDSON; LANGLAND; SIPPY, 1969; RUSHTON; HORNER; WORTHINGTON, 1999; SAMAWI; BURKE, 1984; STRAMOTAS et al., 2002). Dessa forma, os pacientes foram posicionados com o plano oclusal paralelo ao solo e o plano sagital mediano perpendicular ao mesmo.

No entanto, sabe-se que as radiografias panorâmicas, assim como os outros tipos de radiografias extrabucais, apresentam magnificação da imagem real (ALMEIDA; BÓSCOLO; MONTEBELLO FILHO, 1995; BLACKMAN, 1956; BREZDEN; BROOKS, 1987). Tal fato é explicado pela divergência dos raios $X$, que torna o método sensível a alterações na distância e no alinhamento do objeto, filme e fonte de raios X (ALMEIDA; BÓSCOLO; MONTEBELLO FILHO, 1995; GRABER, 1967; PHILLIPS, 1967). Além disso, ao contrário das demais radiografias extrabucais obtidas através de uma exposição estática do objeto aos raios $\mathrm{X}$, esse tipo de radiografia forma-se por meio da movimentação do tubo, o que torna impossível o estabelecimento de um único fator de correção para toda a imagem (ROWSE, 1971). Essa característica produz uma distorção ainda maior das medidas lineares, principalmente no sentido horizontal, variando de 15 a 30 \% (BLACKMAN, 1956; CHRISTEN; SEGRETO, 1968; LANGLAND; SIPPY, 1968). Em contrapartida, as distorções angulares apresentam-se menores e menos críticas (BLACKMAN, 1956; CATIC et al., 1998; FRYKHOLM et al., 1977; LARHEIM; SVANAES, 1986; MATTILA; ALTONEN; HAAVIKKO, 1977; MCKEE et al., 2002; PHILLIP; HURST, 1978; SAMAWI; BURKE, 1984), tornando-se insignificantes quando se tomam os cuidados básicos em relação ao posicionamento de um mesmo paciente entre várias tomadas radiográficas. É importante salientar ainda que uma variação de até 5 graus do posicionamento da cabeça do paciente tem sido considerada clinicamente 
aceitável, quando se comparam duas tomadas radiográficas de um mesmo paciente (FRYKHOLM et al., 1977; PHILLIP; HURST, 1978; SAMAWI; BURKE, 1984). Isso revela a possibilidade do uso da radiografia panorâmica em estudos com medidas angulares com grande acuidade (ALMEIDA et al., 1991; LARHEIM; SVANAES, 1986; MATTILA; ALTONEN; HAAVIKKO, 1977; STRAMOTAS et al., 2002).

Recentemente, uma nova geração de tomógrafos computadorizados com tecnologia 3D foi desenvolvida, sendo alguns deles especialmente para a região maxilofacial, especificamente para a Odontologia. Esse sistema é conhecido como tomografia computadorizada de feixe cônico (cone beam). Essa evolução implica em mudanças em relação aos atuais meios de diagnóstico, já que esse método apresenta uma grande acurácia e precisão em relação à imagem real (PECK et al., 2007). É evidente que esse meio diagnóstico seria o ideal para mensuração das inclinações mesiodistais dos dentes. Contudo, a tomografia computadorizada de feixe cônico (cone bean) ainda não existia quando esta amostra foi composta e o único meio diagnóstico disponível para esse fim foram as radiografias panorâmicas.

De acordo com o Board Americano de Ortodontia, embora a radiografia panorâmica não seja a maneira perfeita para avaliar a inclinação axial mesiodistal das raízes dentárias, representa o método mais viável (CASKO et al., 1998).

Portanto, para a determinação das inclinações mesiodistais dentárias, a radiografia panorâmica demonstrou ser um instrumento de grande valia (ALMEIDAPEDRIN et al., 2006; ALMEIDA-PEDRIN; PINZAN; ALMEIDA, 2001; ALMEIDA, 1999; BRANDÃO, 2002; CUOGHI; SELLA; MENDONÇA, 2010; FRYKHOLM et al., 1977; KANE, 1967; MCKEE et al., 2002; MLYNARSKA-ZDUNIAK, 1983; URSI et al., 1990; URSI, 1989), embora devamos utilizá-la com cautela e com certo conhecimento da existência da distorção da imagem (MCKEE et al., 2001; MCKEE et al., 2002).

\subsection{2 - Inclinação axial mesiodistal}

O principal objetivo do tratamento ortodôntico consiste em posicionar adequadamente os dentes nos três planos do espaço, obtendo assim as seis chaves para uma oclusão normal preconizadas por Andrews (1972), estando entre elas a inclinação axial mesiodistal dos dentes (ANDREWS, 1972; ANDREWS, 1976; BERKOVITZ; HOLLAND; MOXHAM, 1978; DEWEL, 1949; GARINO, 1971; 
PICOSSE, 1990; SICHER, 1970; WHEELER, 1965; YOUNG, 1964), os quais, de maneira geral, apresentam-se com uma angulação da raiz para distal em relação à sua respectiva coroa. O espaço para cada dente varia conforme essas angulações, que, além de um relacionamento adequado no sentido anteroposterior, geram contatos proximais justos (ANDREWS, 1972).

Os longos eixos dentários, quando posicionados corretamente, fornecem condições adequadas para que o equilíbrio oclusal seja atingido e estabelece-se como um importante requisito para obtenção da estabilidade dos resultados gerados pelo tratamento (ANDREWS, 1976; EDWARDS, 1971; HATASAKA, 1976).

Um caso tratado ortodonticamente deve, ao final do tratamento, apresentar a inclinação axial muito próxima à encontrada na oclusão "normal" (URSI et al., 1990). Diversos estudos revelam que, em uma oclusão considerada normal, os dentes encontram-se em equilíbrio, mantendo entre si um posicionamento correto na cavidade bucal e, dessa maneira, exercem sua função adequada. O posicionamento adequado do dente no arco dentário contribui sobremaneira para uma correta distribuição das forças oclusais (BERKOVITZ, 1978; GLICKMAN, 1974; SICHER, 1970; WHEELER, 1965; YOUNG, 1964) o mais próximo possível dos longos eixos dos dentes (BEYRON, 1952; YOUNG, 1964), de modo que essa força seja dissipada por meio dos pontos de contato proximais e forme um componente anterior de força (BERKOVITZ, 1978; DEWEL, 1949; GLICKMAN, 1974), que se inicia na região posterior e caminha para a região anterior, onde ocorre uma neutralização dessa força na linha média, porque há o encontro de duas forças semelhantes em direções opostas (GLICKMAN, 1974).

Em relação aos aspectos ortodônticos, a correta inclinação axial mesiodistal dos dentes representa uma das chaves para obtenção dos objetivos do tratamento (ANDREWS, 1972; ANDREWS, 1976). Quando as inclinações axiais mesiodistais encontram-se inadequadas, a possibilidade de ocorrência de reabertura de espaços fechados por meio do tratamento ortodôntico aumenta em decorrência do paralelismo radicular incorreto (EDWARDS, 1971; GRABER, 1966; HATASAKA, 1976; HOLDAWAY, 1952; STRANG, 1952). O aumento destas angulações pode, ainda, compensar certas discrepâncias de tamanho dentário interarcos e otimizar a estabilidade do alinhamento dentário na região anteroinferior (TUVERSON, 1980). Quanto à estabilidade do posicionamento dentário obtido por meio do tratamento 
ortodôntico e ocorrência de recidiva, Ferrario et al. (2001) explicaram que a alteração da angulação dentária relacionada com a idade pode ser o efeito de um deslocamento mesial progressivo.

A busca para obtenção clínica da inclinação axial mesiodistal correta envolveu desde alterações no posicionamento dos braquetes, (HOLDAWAY, 1952; INTERLANDI, 1986; RENFROE, 1975; ROTH, 1987; VIGORITO, 1984) até a sua incorporação nos acessórios (ANDREWS, 1976; ANDREWS, 1976b, 1976a; CAPELOZZA FILHO et al., 1999; ROTH, 1987). Pesquisas que compararam a efetividade de técnicas, como a de Capelozza Filho et al. (1994), investigações concernentes ao posicionamento mesiodistal dos incisivos permanentes superiores na fase de dentadura mista, como a de Cuoghi et al. (2000), e estudos que avaliaram a obtenção das inclinações axiais mesiodistais corretas comparando-as ao início e ao término do tratamento, como o de Almeida-Pedrin et al. (2006), reiteram a importância do assunto.

Preocupados com a obtenção de uma correta inclinação axial mesiodistal, Ursi et al. (1990) desenvolveram uma pesquisa na qual concluíram que todo caso tratado ortodonticamente deveria apresentar, ao término do tratamento, a mesma inclinação axial mesiodistal de um paciente que possuísse uma oclusão normal. Desse modo, as raízes dos incisivos centrais e laterais superiores devem apresentar-se ligeiramente convergentes e dos demais dentes superiores devem indicar uma inclinação para a distal, com exceção dos segundos molares que possuem inclinação para a mesial. Os incisivos inferiores mostraram-se verticalizados e os outros dentes apresentam uma inclinação que aumenta gradativamente para a distal, corroborando com Garino (1971) e Picosse (1990).

Com base nos relatos da literatura de que seria necessário obter uma correta inclinação axial mesiodistal ao término do tratamento ortodôntico (ALMEIDAPEDRIN; PINZAN; ALMEIDA, 2001; ALMEIDA-PEDRIN et al., 2006; ALMEIDA, 1999; BRANDÃO, 2002; URSI et al., 1990; URSI, 1989), um dos objetivos desta pesquisa consistiu em avaliar se, nos pacientes tratados com distalização dos molares superiores através do uso do aparelho Pendulum, as inclinações obtidas ao término do tratamento apresentaram-se concordes com os valores normais e se essas inclinações se mantiveram estáveis após cinco anos de tratamento. 


\subsection{3 - Traçado de orientação}

O traçado de orientação para medições angulares em radiografias panorâmicas vem sendo amplamente utilizado (ALMEIDA-PEDRIN; PINZAN; ALMEIDA, 2001; ALMEIDA-PEDRIN et al., 2006; BRANDÃO, 2002; CUOGHI et al., 2000; CUOGHI; SELLA; MENDONÇA, 2010; URSI et al., 1990; URSI, 1989). A procura pela técnica ideal constitui o objetivo de diversos trabalhos (CAPELOZZA FILHO; MACHADO, 1994; TAVANO et al., 1989).

A metodologia utilizada para realização dos traçados de orientação seguiu as informações descritas por Tavano et al. (1989), que desenvolveram um protocolo para o traçado das radiografias panorâmicas com objetivo de analisar os posicionamentos dentários. Os autores defenderam que as estruturas anatômicas devem ser traçadas sempre em seu contorno mais externo e pesquisaram as linhas de referência mais indicadas para realização da avaliação das inclinações dentárias mesiodistais em radiografias ortopantomográficas. Concluíram que quanto à exatidão da determinação dos pontos de referência, as linhas que se comportaram melhor foram, respectivamente, a linha interorbital para os dentes superiores e a linha intermentoniana, para os inferiores, em virtude de sua fácil visualização radiográfica e pequena ou quase nenhuma modificação causada pelo crescimento e desenvolvimento da face nesses pontos (TAVANO et al., 1989).

Apesar de existir na literatura o trabalho de Capelozza Filho e Machado (1994), que sugeriram uma nova maneira de determinar o longo eixo do primeiro molar superior, baseando-se na bifurcação das raízes vestibulares, a determinação do longo eixo dos molares seguiu a determinação de acordo com Ursi (1989), ou seja, seguindo o canal radicular da raiz palatina sem considerar nenhum ponto de referência na coroa dentária.

\section{3 - Precisão da metodologia:}

O estudo radiográfico, panorâmico ou cefalométrico, representa um inestimável recurso para o diagnóstico, planejamento e acompanhamento ortodôntico. Embora as pesquisas com radiografias panorâmicas e cefalométricas apresentem alta frequência na literatura científica envolvendo estudos clássicos, é importante salientar que esses estudos revelam certas limitações devido à dificuldade de 
identificação de estruturas anatômicas e alto grau de subjetividade, o que pode acarretar uma imprecisão nos diversos procedimentos envolvidos tais como na realização dos traçados radiográficos, na demarcação dos pontos e na mensuração das medidas utilizadas (HOUSTON, 1983). Por conseguinte, a avaliação dos erros sistemáticos e casuais são recursos indispensáveis em pesquisas científicas que utilizam esta metodologia (GOLDREICH et al., 1998). Para que os resultados deste trabalho sejam confiáveis, procurou-se minimizar os erros dos métodos de mensuração empregados.

Cabe salientar que não houve a necessidade de relevar o fator de magnificação das radiografias para determinação do erro sistemático, pois, além das medidas utilizadas representarem ângulos, que não são alterados pelo fator de magnificação, todas as radiografias foram obtidas seguindo uma correta padronização, sem diferenças quanto a essa característica.

Para avaliação do erro intraexaminador, foram selecionados aleatoriamente 6 pacientes compreendendo um total de $30 \%$ da amostra. Foram retraçadas três radiografias de cada paciente, sendo uma da fase inicial, uma da final e outra da fase cinco anos pós-tratamento. $O$ traçado e a medição das 18 radiografias selecionadas foram realizados exatamente nas mesmas condições e seguindo rigorosamente os mesmos critérios utilizados para o traçado e mensuração dos ângulos de todas as panorâmicas que compuseram a amostra.

O erro casual, calculado pela fórmula proposta por Dahlberg (1940), surge diante da dificuldade de identificação e definição de certos pontos radiográficos, pois muitos desses pontos apresentam dificuldade na sua demarcação, e a opinião do examinador, quanto à sua correta localização, pode variar. No presente estudo o erro casual variou de $0,91^{\circ}$ a $1,50^{\circ}$, e de acordo co m Sandler (1988), Liu e Gravelly (1991) e Almeida-Pedrin et al. (2001), o valor do índice de Dahlberg é considerado relevante apenas quando acima de $1,50^{\circ}$. Ao analisar mos os resultados (Tabela 3 ), observamos que nenhuma das variáveis apresenta valores acima de 1,50\%, constatando-se, assim, a satisfatória precisão da metodologia.

O erro sistemático, calculado pelo teste t pareado com valor de $p<0,05$, se manifesta quando um examinador altera sua técnica de mensuração com o passar do tempo e de modo inconsciente, tende a sub ou superestimar os valores de acordo com o resultado esperado em sua pesquisa, refletindo uma falta de padronização do método. Ao analisar os resultados obtidos (Tabela 3), observa-se 
que nenhuma das variáveis mostra diferença estatisticamente significante, o que indica a precisão da metodologia.

Desta forma, pode-se considerar que a metodologia empregada expressou satisfatória precisão, o que dá confiabilidade aos resultados deste trabalho.

\section{4 - Resultados}

Os valores das inclinações axiais mesiodistais obtidos nas fases inicial (T1), final (T2) e cinco anos pós-tratamento (T3) foram comparados entre si e, posteriormente, com os valores médios normais propostos por Ursi em 1989. Os resultados das análises estatísticas estão expostos nas tabelas 4 a 12, e, com base nessas tabelas, os resultados apresentados abaixo serão discutidos.

\subsection{1 - Primeiros Molares Superiores Direito (16) e Esquerdo (26)}

Ao início do tratamento, os molares superiores direito e esquerdo apresentavam a inclinação axial mesiodistal semelhante aos valores médios normais propostos por Ursi (1989). Isso nos revela que, mesmo em casos de má oclusão de Classe II, a inclinação dos molares se mostrou adequada. Ao final do tratamento, os primeiros molares superiores mostraram uma inclinação para a distal maior do que o normal (Figura 9), o que já era esperado, visto que o aparelho Pendulum, bem como todos os distalizadores intrabucais, tendem a inclinar os molares para a distal, devido a fatores inerentes da própria mecânica (ANGELIERI et al., 2006; BONDEMARK; KUROL, 1992; BRICKMAN; SINHA; NANDA, 2000; BUSSICK; MCNAMARA, 2000; BYLOFF; DARENDELILER, 1997; BYLOFF et al., 1997; CHAQUES-ASENSI; KALRA, 2001; FUZIY et al., 2006; GHOSH; NANDA, 1996; ITOH et al., 1991; JOSEPH; AUTCHART, 2000; RUNGE; MARTIN; BUKAI, 1999; SANTOS et al., 2007; SANTOS et al., 2006; SILVA FILHO et al., 2007).

No entanto, somente o primeiro molar esquerdo apresentou valor estatisticamente significante em relação aos valores normais. Especula-se que houve essa falta de significância estatística do primeiro molar direito devido ao amplo desvio padrão apresentado pela amostra de Ursi (1989). Quando comparadas entre si, as fases T1 e T2 apresentaram diferença estatisticamente significante para os primeiros molares superiores. 
Na tentativa de evitar a inclinação exagerada do molar para a distal foram realizadas dobras de anti-inclinação, para que houvesse um maior controle sobre a inclinação distal das coroas dos molares (FUZIY et al., 2006). Além disso, logo após a distalização, os pacientes utilizaram aparelho extrabucal de tração cervical, de uso noturno com o intuito de verticalizar as raízes e colaborar na contenção dos molares distalizados (ANGELIERI et al., 2006). Dobras compensatórias nas molas distalizadoras podem favorecer a movimentação das raízes para distal, mas são incapazes de fazer com que o movimento do dente seja por translação ao invés de inclinação. Os precursores desta dobra foram Byloff et al. (1997) que estudaram o efeito de incorporação desta dobra na mola distalizadora com a finalidade de corrigir a inclinação da raiz depois da distalização da coroa dos molares. Eles encontraram uma menor inclinação dos molares nos aparelhos com a incorporação da dobra, apesar de não terem obtido um movimento de corpo, ou seja, mesmo lançando mão de todos estes artifícios para evitar a inclinação do molar e em seguida tentar a verticalização da raiz, o primeiro molar superior permanece mais inclinado para distal ao final do tratamento com aparelho fixo. O aparelho extrabucal, em conjunto com o fixo, não consegue verticalizar as raízes a valores próximos do apresentado ao início do tratamento.

Entretanto, a inclinação foi reduzida a valores próximos do normal no quinto ano pós-tratamento, ou seja, após o término do tratamento, os primeiros molares superiores tenderam a verticalizarem-se (ALESSIO JR, 2009; BADELL, 1976; MELSEN; DALSTRA, 2003), voltando a apresentar valores próximos aos valores médios normais propostos por Ursi (1989). Quando comparadas entre si, as fases T2 e T3 apresentaram diferença estatisticamente significante para os primeiros molares superiores. Martinelli et al. (2010), avaliando as alterações naturais da inclinação axial dos primeiros molares superiores em indivíduos com má oclusão de Classe II, viram também que esses dentes revelam uma tendência natural de verticalizar a inclinação distal apresentada por eles com o tempo. Estas informações vão ao encontro dos achados de Badel (1976), que observou uma forte tendência de verticalização dos molares superiores após o uso do AEB. Melsen e Dalstra (2003) demonstraram que o deslocamento do molar para a distal pelo aparelho extrabucal retornou mesialmente para recuperar uma posição comparável à de indivíduos não tratados. Isto porque a cúspide lingual do molar superior permanece encaixada na fossa central do molar inferior e esta posição é mantida pela transferência das 
cargas oclusais. Portanto, a inclinação molar para mesial não indica uma tendência à recidiva da relação molar de Classe I obtida durante o tratamento, pois a relação sagital do molar foi mantida. Esses achados podem ser suportados pelo trabalho de Alessio Jr (2009) que avaliou a estabilidade do tratamento da má oclusão de Classe II, corrigida com o aparelho Pendulum e observou, em telerradiografias, que a relação molar não apresentou diferença estatisticamente significante ao final do tratamento em relação ao longo tempo pós-tratamento, assim como o índice PAR não apresentou diferença estatística entre os períodos.

Além disso, os distalizadores, também, por realizarem uma distalização rápida dos molares superiores e geralmente causarem uma inclinação para distal da coroa, podem aumentar a recidiva (MAVROPOULOS et al., 2005; NGANTUNG; NANDA; BOWMAN, 2001). Elms, Buschang e Alexander (1996) afirmaram que, a cada $3^{\circ} \mathrm{de}$ inclinação do molar para trás, haverá cerca de $1^{\circ} \mathrm{d}$ e recidiva.

Há ainda um componente horizontal de forças mesiais durante a mastigação, sugerindo que a causa desta inclinação para mesial é uma tendência de adaptá-lo às demandas funcionais (SOUTHARD; SOUTHARD; TOLLEY, 1992).

Kinzinger et al. (2004) observaram uma maior inclinação dos primeiros molares superiores durante o tratamento com Pendulum em indivíduos que não apresentavam os segundos molares superiores irrompidos. Segundo o autor, a justificativa desta maior inclinação é o fulcro criado no ponto de contato entre a raiz do primeiro molar e a coroa do segundo molar. Graber (1955) também observou que, quando a tração extrabucal foi aplicada aos primeiros molares, essa inclinação foi maior na ausência dos segundos molares irrompidos. No presente estudo todos os indivíduos tratados mostravam os segundos molares irrompidos. No entanto, se os primeiros e segundos molares são distalizados simultaneamente por meio do Pendulum, a duração da distalização será maior, maiores forças terão de ser aplicadas e mais ancoragem será perdida (GIANCOTTI; COZZA, 1998; HILGERS, 1992; KINZINGER et al., 2004). Outros autores (BUSSICK; MCNAMARA, 2000; JOSEPH; AUTCHART, 2000) também observaram uma maior inclinação durante o tratamento em casos nos quais não havia os segundos molares irrompidos. 


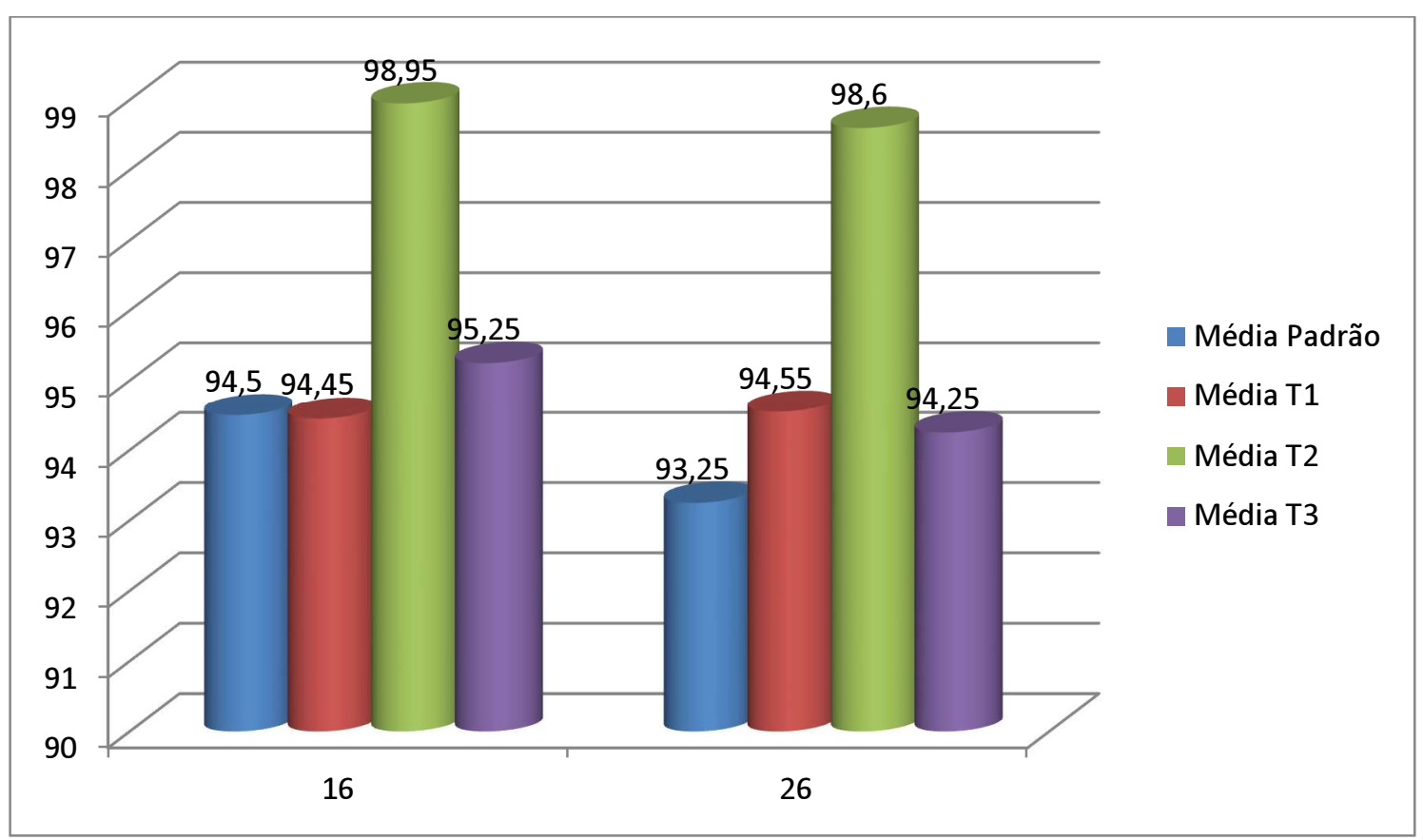

Figura 9: Valores médios das inclinações axiais mesiodistais dos primeiros molares superiores direito (16) e esquerdo (26)

\subsection{2 - Segundos Molares Superiores Direito (17) e Esquerdo (27)}

Ao início do tratamento, os segundos molares superiores direito e esquerdo, apresentavam uma leve inclinação para mesial, apesar de esta não se apresentar estatisticamente significante em relação aos valores normais (Figura 10). Ao final do tratamento, esses dentes mostraram uma moderada inclinação para a distal, ainda condizente, porém, com os valores normais, sendo que, cinco anos pós-tratamento, esses dentes apresentaram uma suave verticalização. As alterações da inclinação axial mesiodistal dos segundos molares superiores nas fases T1, T2 e T3 não se apresentaram estatisticamente significantes quando comparadas entre si, nem quando comparadas com os valores normais.

Isso já era esperado, já que, no aparelho Pendulum, a força é aplicada nos primeiros molares superiores, não influenciando de maneira significativa a inclinação dos segundo molares superiores. 


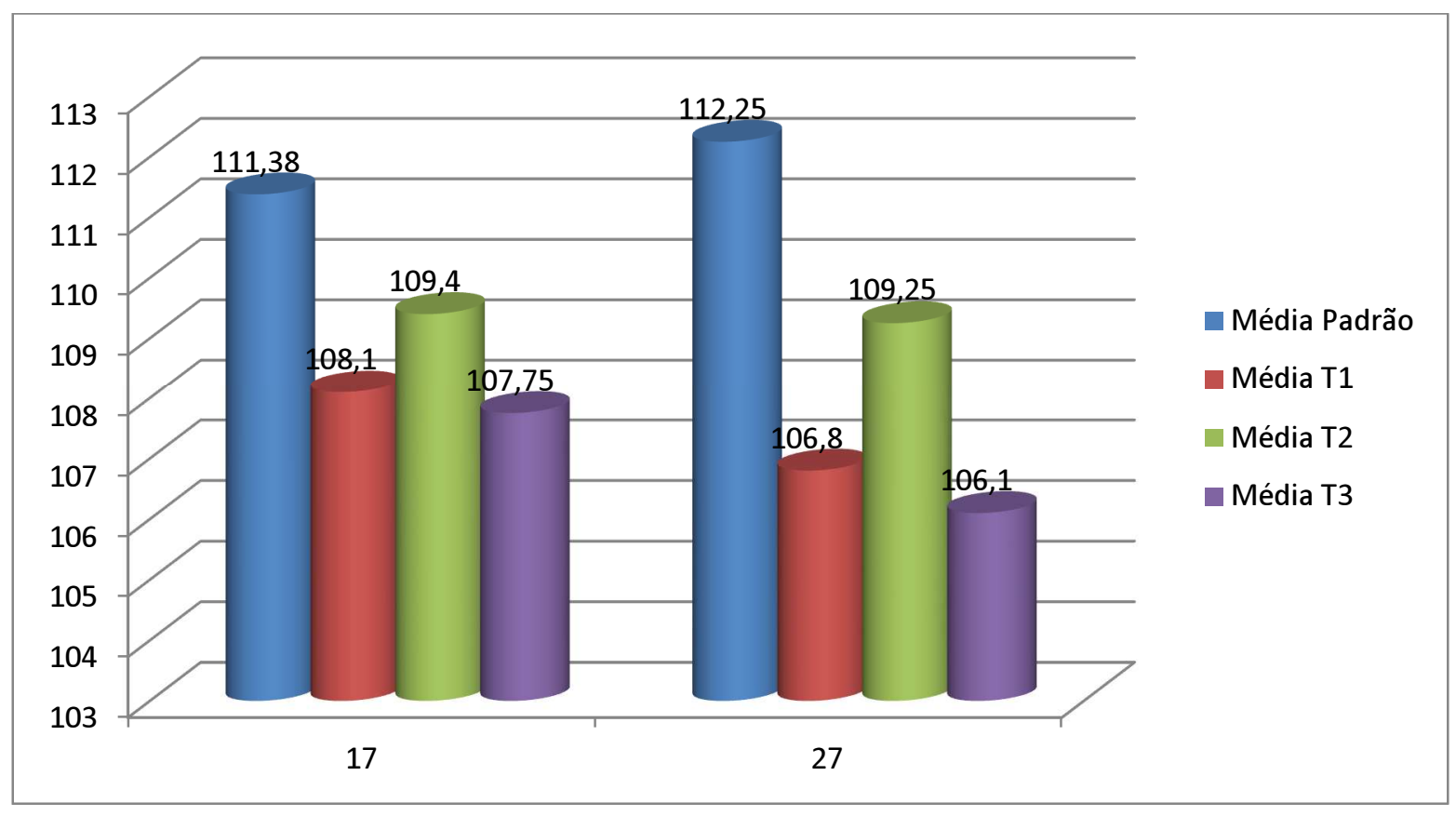

Figura 10: Valores médios das inclinações axiais mesiodistais dos segundo molares superiores direito (17) e esquerdo (27)

\section{5 - Considerações clínicas}

A inclinação distal dos molares durante sua distalização é previsivelmente extensiva a todos os distalizadores intrabucais, não se restringindo ao efeito do aparelho Pendulum (ANGELIERI et al., 2006; BUSSICK; MCNAMARA, 2000; BYLOFF; DARENDELILER, 1997; CHAQUES-ASENSI; KALRA, 2001; FUZIY et al., 2006; GHOSH; NANDA, 1996; JOSEPH; AUTCHART, 2000; SANTOS et al., 2007; SANTOS et al., 2006). A explicação mecânica para a inclinação está na localização do ponto de aplicação da força em relação ao centro de resistência do molar e na impossibilidade em fazer com que a linha de ação de força passe pelo centro de resistência. Essa inclinação para distal não desqualifica o resultado, mas impõe limites na quantidade de distalização possível durante o planejamento ortodôntico, bem como exige providências durante a execução da distalização, como o uso de dobra anti-inclinação, sobrecorreção e a estabilização do molar distalizado depois da suspensão do aparelho distalizador. 
As dobras compensatórias nas molas distalizadoras não cumprem em toda plenitude a função anunciada de distalizar a raiz dos molares distalizados (BYLOFF; DARENDELILER, 1997; SANTOS et al., 2007), pelo menos de um modo geral.

A utilização destes recursos é importante, pois, como observado no presente estudo, o primeiro molar superior tende a mesializar durante o período cinco anos pós-tratamento (ALESSIO JR, 2009; FUZIY, 2001; GIANELLY, 1998). Como controle da ancoragem durante a retração anterossuperior, deve-se lançar mão dos elásticos de Classe II, aparelho extrabucal de tração cervical, ou até da distalização sequencial dos molares, iniciando-se com os segundos molares, e finalmente, os primeiros molares (ANGELIERI et al., 2006; FUZIY et al., 2006; HILGERS, 1992). Os dispositivos utilizados durante o período de retração atuam como uma contenção ativa, e, além de manter os molares em posição, reforçam a contenção e proporcionam a verticalização das raízes dos molares distalizados.

Mesmo lançando mão de todos esses recursos, pode-se observar neste estudo que, ao final do tratamento ortodôntico com aparelhagem fixa os primeiros molares superiores terminam mais inclinados para a distal.

No entanto, constatou-se que cinco anos após o tratamento os molares apresentaram uma inclinação para mesial, ou seja, tenderam a verticalizarem-se. Isso se explica pelo componente anterior de força que é um dos fatores que afeta a dinâmica da posição dentária no sentido sagital (VARDIMON et al., 2007). Esse é um vetor vertical derivado da força mastigatória, que contribui para o movimento mesial dos dentes posteriores (SOUTHARD; BEHRENTS; TOLLEY, 1990).

Quanto à estabilidade do posicionamento dentário obtido por meio do tratamento ortodôntico e ocorrência de recidiva, Ferrario et al. (2001) explicaram que a alteração da inclinação mesiodistal dentária relacionada com a idade pode ser 0 efeito de um deslocamento mesial progressivo.

Observa-se na literatura que o tratamento ortodôntico busca a obtenção de um correto paralelismo radicular e, consequentemente, um resultado estável ao término do tratamento ortodôntico (ALMEIDA-PEDRIN; PINZAN; ALMEIDA, 2001; ALMEIDA-PEDRIN et al., 2006; ANDREWS, 1972; ANDREWS, 1976; DEWEL, 1949; PICOSSE, 1990; WHEELER, 1965), devendo o profissional, estar atento às inclinações tanto ao início quanto, principalmente ao término e nos anos de acompanhamento pós-tratamento e, para isso, as radiografias panorâmicas mostraram ser um valioso instrumento que permite a análise das inclinações 
(ALMEIDA-PEDRIN; PINZAN; ALMEIDA, 2001; ALMEIDA-PEDRIN et al., 2006; BRANDÃO, 2002; FRYKHOLM et al., 1977; KANE, 1967; MCKEE et al., 2002; MLYNARSKA-ZDUNIAK, 1983; URSI et al., 1990; URSI, 1989) em todas as fases do tratamento (ALMEIDA-PEDRIN et al., 2006; CAPELOZZA FILHO et al., 1994; CAPELOZZA FILHO; MACHADO, 1994; URSI et al., 1990; URSI, 1989), possibilitando a correção ou manutenção das inclinações axiais mesiodistais e auxiliando a finalização de um tratamento ortodôntico com resultados mais estáveis.

A tendência de verticalização dos molares que já foi mostrada em estudos em indivíduos não tratados (CARTER, 1987; FERRARIO et al., 2001; MARTINELLI et al., 2010) foi também observada neste trabalho em pacientes tratados. Trata-se de um fato relevante, pois a inclinação axial correta é uma meta a ser atingida durante a finalização ortodôntica, uma vez que propicia um adequado paralelismo radicular e melhor distribuição de forças oclusais (ANDREWS, 1972; ANDREWS, 1976; BERKOVITZ, 1978; DEWEL, 1949; GARINO, 1971; PICOSSE, 1990; SICHER, 1970; WHEELER, 1965; YOUNG, 1964). Desta forma, mesmo quando não obtida ao final do tratamento ortodôntico, há uma tendência de melhora da inclinação axial mesiodistal favorecendo a estabilidade em longo prazo, já que os longos eixos dentários, quando posicionados corretamente, fornecem condições adequadas para que o equilíbrio oclusal seja atingido e estabelece-se como um importante requisito para obtenção da estabilidade dos resultados gerados pelo tratamento (ANDREWS, 1976; EDWARDS, 1971; HATASAKA, 1976).

\section{6 - Sugestão de estudos futuros}

Avaliar a estabilidade da relação molar após o tratamento da má oclusão de Classe II por meio do uso do aparelho Pendulum seguido de aparelhagem ortodôntica fixa em pacientes na fase da dentadura mista. 


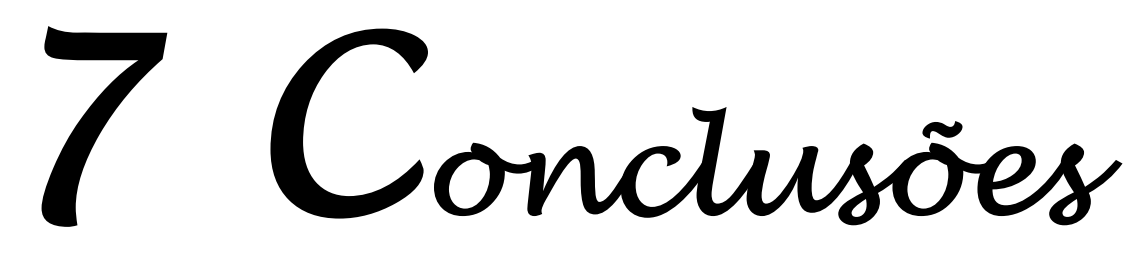





\section{CONCLUSÕES}

De acordo com a metodologia utilizada, com os resultados e discussão apresentados, pode-se concluir:

7.1- as inclinações mesiodistais dos molares na fase inicial (T1) do tratamento ortodôntico mostraram-se próximas das observadas em uma oclusão normal.

7.2- ao término do tratamento (T2), os primeiros molares apresentaram as coroas mais inclinadas para a distal, os segundos molares não apresentaram diferença estatisticamente significante, porém, apenas o primeiro molar superior esquerdo evidenciou uma inclinação mesiodistal diferente das observadas na oclusão normal.

7.3- após cinco anos do término do tratamento (T3), os molares tenderam a verticalizarem-se, quando comparados com a fase final (T2), apresentando valores médios semelhantes aos valores iniciais e de uma oclusão normal. 

Referencias 



\section{REFERÊNCIAS}

Ackerman JL, Proffit WR. The characteristics of malocclusion: a modern approach to classification and diagnosis. Am J Orthod. 1969;56(5):443-54.

Alessio Jr LE. Avaliação longitudinal da estabilidade do tratamento da má oclusão de Classe II com o aparelho Pendulum seguido pelo aparelho fixo [dissertação]. Bauru (SP): Faculdade de Odontologia de Bauru, Universidade de São Paulo; 2009.

Almeida-Pedrin RR, Pinzan A, Almeida RR. Estudo ortopantomográfico das inclinações axiais dos dentes anteriores, comparando pacientes tratados ortodonticamente e jovens com oclusão normal. Rev Dental Press Ortodont Ortop Facial. 2001;6(5):31-47.

Almeida-Pedrin RR, Pinzan A, Almeida RR, Ursi W, de Almeida MR. Panoramic evaluation of mesiodistal axial inclinations of maxillary anterior teeth in orthodontically treated subjects. Am J Orthod Dentofacial Orthop. 2006;130(1):56-60.

Almeida-Pedrin RR, Henriques JF, Almeida RR, de Almeida MR, McNamara JA, Jr. Effects of the pendulum appliance, cervical headgear, and 2 premolar extractions followed by fixed appliances in patients with Class II malocclusion. Am J Orthod Dentofacial Orthop. 2009;136(6):833-42.

Almeida MR, Freitas MR, Almeida RR, Almeida RR, Henriques JFC. A correção da Classe II de Angle utilizando o aparelho de Jones Jig - Apresentação de um caso clínico. J bras ortodon ortop facial. 2000;5(27):9-20.

Almeida RR, Martins DR, Pretti H, Ursi WJS . Determinação do ângulo goníaco: telerradiografia x ortopantomografia. Rev Odont USP. 1991;5(2):118-23.

Almeida RR. Estudo ortopantomográfico das inclinações axiais dos dentes anteriores, comparando pacientes tratados ortodonticamente e jovens com oclusão normal [dissertação]. Bauru (SP): Faculdade de Odontologia de Bauru, Universidade de São Paulo; 1999.

Almeida SM, Bóscolo FN, Haiter Neto F. Erros em radiografias panorâmicas. Rev Odont Brasil Central-ROBRAC. 1995;5(16):25-9. 
Almeida SM, Bóscolo FN, Montebello Filho A. Estudo das distorções da imagem radiográfica produzida em aparelhos panorâmicos que se utilizam dos princípios ortopantomográficos e elipsopantomográficos. Rev Odont USP. 1995;9(2):91-9.

Alpern MC. Analysis of panoramic cephalometrics using s skeletal cephalostat. Angle Orthod. 1979;49(2):110-20.

Alpern MC. Clinical radiography in the orthodontic practice. Angle Orthod. $1984 ; 54(3): 233-46$.

Alvares LC, Tavano O. Curso de radiologia em odontologia. 3.ed. São Paulo,. Editora Santos. 1993.

Andreasen G, Naessig C. Experimental findings on mesial relapse of maxillary first molars. Angle Orthod. 1968;38(1):51-5.

Andrews LF. The six keys to normal occlusion. Am J Orthod. 1972;62(3):296-309.

Andrews LF. The straight wire appliance. Syllabus of philosophy and techniques. San Diego: Larry F. Andrews Foundation for Orthodontic Education and Research; 1975.

Andrews LF. The straight-wire appliance. Explained and compared. J Clin Orthod. 1976a;10(3):174-95.

Andrews LF. The straight-wire appliance, origin, controversy, commentary. J Clin Orthod. 1976b;10(2):99-114.

Andrews LF. The diagnostic system: occlusal analysis. Dent Clin N Amer. $1976 ; 20(4): 671-90$.

Angelieri F. Avaliação cefalométrica pós-distalização realizada por meio do aparelho Pendulum, em pacientes em tratamento ortodôntico com aparelho fixo [dissertação]. Bauru (SP): Faculdade de Odontologia de Bauru, Universidade de São Paulo; 2002.

Angelieri F, Almeida RR, Almeida MR, Fuziy A. Dentoalveolar and skeletal changes associated with the pendulum appliance followed by fixed orthodontic treatment. Am J Orthod Dentofacial Orthop. 2006;129(4):520-7. 
Angelieri F, de Almeida RR, Janson G, Castanha Henriques JF, Pinzan A. Comparison of the effects produced by headgear and pendulum appliances followed by fixed orthodontic treatment. Eur J Orthod. 2008;30(6):572-9.

Angle E. Classification of malocclusion. Dent Cosmos. 1899;41:246-64.

Armstrong MM. Controlling the magnitude, direction, and duration of extraoral force. Am J Orthod. 1971;59(3):217-43.

Arvystas MG. Nonextraction treatment of Class II, Division 1 malocclusions. Am J Orthod. 1985;88(5):380-95.

Ast DB, Carlos JP, Cons NC. The Prevalence and Characteristics of Malocclusion among Senior High School Students in Upstate New York. Am J Orthod. 1965;51:437-45.

Baccetti T, Franchi L, McNamara JA, Jr., Tollaro I. Early dentofacial features of Class II malocclusion: a longitudinal study from the deciduous through the mixed dentition. Am J Orthod Dentofacial Orthop. 1997;111(5):502-9.

Badell MC. An evaluation of extraoral combined high-pull traction and cervical traction to the maxilla. Am J Orthod. 1976;69(4):431-46.

Baumirind S. The decision to extract: Part II. Analysis of clinician's stated reasons for extraction. Am J Orthod Dentofacial Orthop. 1996;109(4):393-402.

Bell WH, Jacobs JD, Legan HL. Treatment of Class II deep bite by orthodontic and surgical means. Am J Orthod. 1984;85(1):1-20.

Berkovitz BKB, Holland, GR, Moxham, BJ. The alignment and occlusion of the permanent teeth. In: Berkovitz BKB, Holland, GR, Moxham, BJ. A colour atlas \& textbook of oral anatomy. London: Wolfe Medical; 1978. p. 35-41.

Bertoz FA. Características cefalométricas de pacientes com má oclusão Classe II. Rev APEO. 2003;1(1):35-41.

Beyron HL. Occlusal relationship. Int dent J. 1952;2(4):467-96. 
Binda SK, Kuijpers-Jagtman AM, Maertens JK, van 't Hof MA. A long-term cephalometric evaluation of treated Class II division 2 malocclusions. Eur $\mathrm{J}$ Orthod. 1994;16(4):301-8.

Bishara SE, Cummins DM, Jakobsen JR. The morphologic basis for the extraction decision in Class II, division 1 malocclusions: a comparative study. Am J Orthod Dentofacial Orthop. 1995;107(2):129-35.

Bishara SE, Cummins DM, Jakobsen JR, Zaher AR. Dentofacial and soft tissue changes in Class II, division 1 cases treated with and without extractions. Am J Orthod Dentofacial Orthop. 1995;107(1):28-37.

Bishara SE, Jakobsen JR, Vorhies B, Bayati P. Changes in dentofacial structures in untreated Class II division 1 and normal subjects: a longitudinal study. Angle Orthod. 1997;67(1):55-66.

Bishara SE, Zaher AR, Cummins DM, Jakobsen JR. Effects of orthodontic treatment on the growth of individuals with Class II division 1 malocclusion. Angle Orthod. 1994;64(3):221-30.

Bjerklin K, Kurol J. Ectopic eruption of the maxillary first permanent molar: etiologic factors. Am J Orthod. 1983;84(2):147-55.

Blackman S. Mass dental radiography. Radiography. 1956;22(254):21-5.

Blackman S. Rotational tomography of the face. Brit J Radiol. 1960;33(391):408-18.

Block MS, Hoffman DR. A new device for absolute anchorage for orthodontics. Am J Orthod Dentofacial Orthop. 1995;107(3):251-8.

Bolla E, Muratore F, Carano A, Bowman SJ. Evaluation of maxillary molar distalization with the distal jet: a comparison with other contemporary methods. Angle Orthod. 2002;72(5):481-94.

Bondemark L, Holm AK, Hansen K, Axelsson S, Mohlin B, Brattstrom V, et al. Longterm stability of orthodontic treatment and patient satisfaction. A systematic review. Angle Orthod. 2007;77(1):181-91. 
Bondemark L, Kurol J. Distalization of maxillary first and second molars simultaneously with repelling magnets. Eur J Orthod. 1992;14(4):264-72.

Brandão AG. Estudo ortopantomográfico longitudinal das inclinações axiais mesiodistais em pacientes tratados ortodonticamente com extrações dos quatro primeiros pré-molares [dissertação]. Bauru (SP): Faculdade de Odontologia de Bauru, Universidade de São Paulo; 2002.

Brezden NA, Brooks SL. Evaluation of panoramic dental radiographs taken in private practice. Oral Surg Oral Med Oral Pathol. 1987;63(5):617-21.

Brickman CD, Sinha PK, Nanda RS. Evaluation of the Jones jig appliance for distal molar movement. Am J Orthod Dentofacial Orthop. 2000;118(5):526-34.

Brusola JAC. Ortodoncia clinica. Barcelona: Salvat Editores; 1989.

Burkhardt DR, McNamara JA, Jr., Baccetti T. Maxillary molar distalization or mandibular enhancement: a cephalometric comparison of comprehensive orthodontic treatment including the pendulum and the Herbst appliances. Am J Orthod Dentofacial Orthop. 2003;123(2):108-16.

Burstone CJ. Beta titanium: a new orthodontic alloy. Am J Orthod. 1980;77(2):12132.

Bussick TJ, McNamara JA, Jr. Dentoalveolar and skeletal changes associated with the pendulum appliance. Am J Orthod Dentofacial Orthop. 2000;117(3):333-43.

Byloff FK, Darendeliler MA. Distal molar movement using the pendulum appliance. Part 1: Clinical and radiological evaluation. Angle Orthod. 1997;67(4):249-60.

Byloff FK, Darendeliler MA, Clar E, Darendeliler A. Distal molar movement using the pendulum appliance. Part 2: The effects of maxillary molar root uprighting bends. Angle Orthod. 1997;67(4):261-70.

Capelli J. Avaliação de interesse clínico entre a radiografia panorâmica e o conjunto periapical aplicado à clínica odontológica. Rev Inst Cienc Saúde. 1991;9(2):59-68. 
Capelozza Filho L, Machado GB, Ozawa TO, Trevisi HJ. Angulação dentária após o tratamento ortodôntico pela técnica de Andrews e Edgewise: avaliação pela ortopantomografia. Ortodontia. 1994;27(2):60-5.

Capelozza Filho L, Silva Filho OG, Ozawa TO, Cavassan AO. Individualização de braquetes na técnica de straight wire: revisão de conceitos e sugestão de indicações para uso. Rev Dental Press Ortodon Ortop Facial. 1999;4(4):87-106.

Capelozza Filho L, Machado GB. Inclinação axial mésio-distal do primeiro molar superior na ortopantomografia: sugestão de modificação do método de avaliação. Rev Soc bras Ortodont. 1994;2(5):142-4.

Carano A, Testa M. The distal jet for upper molar distalization. J Clin Orthod. 1996;30(7):374-80.

Carano A, Testa M, Siciliani G. The lingual distalizer system. Eur J Orthod. $1996 ; 18(5): 445-8$.

Carter NE. Dentofacial changes in untreated Class II division 1 subjects. Br J Orthod. 1987;14(4):225-34.

Casko JS, Vaden JL, Kokich VG, Damone J, James RD, Cangialosi TJ, et al. Objective grading system for dental casts and panoramic radiographs. American Board of Orthodontics. Am J Orthod Dentofacial Orthop. 1998;114(5):589-99.

Catic A, Celebic A, Valentic-Peruzovic M, Catovic A, Jerolimov V, Muretic I. Evaluation of the precision of dimensional measurements of the mandible on panoramic radiographs. Oral Surg Oral Med Oral Pathol Oral Radiol Endod. 1998;86(2):242-8.

Celenza F, Hochman MN. Absolute anchorage in orthodontics: direct and indirect implant-assisted modalities. J Clin Orthod. 2000;34(7):397-402.

Cetlin NM, Ten Hoeve A. Nonextraction treatment. J Clin Orthod. 1983;17(6):396413.

Chaques-Asensi J, Kalra V. Effects of the pendulum appliance on the dentofacial complex. J Clin Orthod. $2001 ; 35(4): 254-7$. 
Chiles JL, Gores RJ. Anatomic interpretation of the orthopantomogram. Oral Surg Oral Med Oral Pathol. 1973;35(4):564-74.

Christen AG, Segreto VA. Distortion and artifacts encountered in Panorex radiography. J Am Dent Assoc. 1968;77(5):1096-101.

Ciger S, Aksu M, Germec D. Evaluation of posttreatment changes in Class II Division 1 patients after nonextraction orthodontic treatment: cephalometric and model analysis. Am J Orthod Dentofacial Orthop. 2005;127(2):219-23.

Clemmer EJ, Hayes EW. Patient cooperation in wearing orthodontic headgear. Am J Orthod. 1979;75(5):517-24.

Craig CE. The skeletal patterns characteristic of Class I and Class II, Division I malocclusions in norma lateralis. Angle Orthod. 1951;21(1):44-56.

Cuoghi OA, Bertoz FA, Mendonça MR, Santos EC, Li AT. Labiolingual and mesiodistal positioning of maxillary permanent incisors during the eruption process. $J$ Clin Pediatr Dent. 2000;25(1):13-21.

Cuoghi OA, Sella RC, Mendonça MR. Mesiodistal angulations of the mandibular canines, premolars and molars with or without the presence of third molars. Eur $\mathrm{J}$ Orthod. 2010;32(4):472-6.

Dahlberg. Statistical methods for medical and biological students. New York: Interscience; 1940.

Dempster WT, Adams, H.J., Duddles, R.A. Arrangement in the jaws of the roots of the teeth. J Amer dent Ass. 1963;67(6):779-97.

Dermaut LR, van den Eynde F, de Pauw G. Skeletal and dento-alveolar changes as a result of headgear activator therapy related to different vertical growth patterns. Eur J Orthod. 1992;14(2):140-6.

Derringer K. A cephalometric study to compare the effects of cervical traction and Andresen therapy in the treatment of class II division 1 malocclusion. Part 2-Dentoalveolar changes. Br J Orthod. 1990;17(2):89-99. 
Dewel BF. Clinical observations on the axial inclination of teeth. Am J Orthod. 1949;35(2):98-115.

Doruk C, Agar U, Babacan $\mathrm{H}$. The role of the headgear timer in extraoral cooperation. Eur J Orthod. 2004;26(3):289-91.

Edwards JG. The prevention of relapse in extraction cases. Am J Orthod. $1971 ; 60(2): 128-44$.

Elms TN, Buschang PH, Alexander RG. Long-term stability of Class II, Division 1, nonextraction cervical face-bow therapy: II. Cephalometric analysis. Am J Orthod Dentofacial Orthop. 1996;109(4):386-92.

Enacar A, Altay OT, Haydar B. Orthodontic intervention in adult patients as an adjunct to prosthetic and restorative dentistry. J Nihon Univ Sch Dent. 1992;34(1):506.

Ferrario VF, Sforza C, Colombo A, Ciusa V, Serrao G. Three-dimensional inclination of the dental axes in healthy permanent dentitions--A cross-sectional study in a normal population. Angle Orthod. 2001;71(4):257-64.

Fidler BC, Artun J, Joondeph DR, Little RM. Long-term stability of Angle Class II, division 1 malocclusions with successful occlusal results at end of active treatment. Am J Orthod Dentofacial Orthop. 1995;107(3):276-85.

Fisk G. The morphology and physiology of distocclusion. Am J Orthod. 1953;39:3-12.

Fogle LL, Southard KA, Southard TE, Casko JS. Treatment outcomes of growing Class II Division 1 patients with varying degrees of anteroposterior and vertical dysplasias, Part 1. Cephalometrics. Am J Orthod Dentofacial Orthop. 2004;125(4):450-6.

Freitas A. Radiografias panorâmicas. In: Alvares LC, Tavano O. Curso de radiologia em odontologia. 3 ed. São Paulo: Editora Santos; 1993. p. 42-8.

Freitas A, Rosa JE, Souza IF. Radiologia odontológica. 4.ed. São Paulo: Artes Médicas; 1998. 
Freitas A, Torres FA. Radiografias panorâmicas. In: Freitas A, Rosa JE, Souza IF. Radiologia odontológica. 4ed. São Paulo: Artes Médicas; 1998. p. 211-36.

Freitas MR, Freitas DS, Pinheiro FHSL, Freitas KMS. Prevalência das más oclusões em pacientes inscritos para tratamento ortodôntico na Faculdade de Odontologia de Bauru - USP. Rev Fac Odontol Bauru. 2002;10(3):194-9.

Frykholm A, Malmgren O, Samfors KA, Welander U. Angular measurements in orthopantomography. Dentomaxillofac Radiol. 1977;6(2):77-81.

Fuziy A. Estudo das alteraçöes sagitais, verticais e transversais decorrentes da distalizaçäo dos molares superiores com o aparelho Pendulum [tese]. Bauru (SP): Faculdade de Odontologia de Bauru, Universidade de São Paulo; 2001.

Fuziy A, Almeida RR, Janson G, Angelieri F, Pinzan A. Sagittal, vertical, and transverse changes consequent to maxillary molar distalization with the pendulum appliance. Am J Orthod Dentofacial Orthop. 2006;130(4):502-10.

Gardiner JH, Mills KM. Panoramic x-ray techniques in orthodontic diagnosis. Orthodontist. 1971;3(1):12-7.

Garino RR. Sistema dentário. In: Aprile H, Figun ME, Garino RR. Anatomia odontologica orocervicofacial. Buenos Aires: El Ateneo; 1971. p. 302-516.

Ghosh J, Nanda RS. Evaluation of an intraoral maxillary molar distalization technique. Am J Orthod Dentofacial Orthop. 1996;110(6):639-46.

Giancotti A, Cozza P. Nickel titanium double-loop system for simultaneous distalization of first and second molars. J Clin Orthod. 1998;32(4):255-60.

Gianelly A. Dr. Anthony Gianelly on current issues in orthodontics. Interview by Dr. Larry W. White. J Clin Orthod. 1996;30(8):439-46.

Gianelly AA. Distal movement of the maxillary molars. Am J Orthod Dentofacial Orthop. 1998;114(1):66-72.

Gianelly AA, Vaitas AS, Thomas WM, Berger DG. Distalization of molars with repelling magnets. J Clin Orthod. 1988;22(1):40-4. 
Gilbert SG. Orthodontics and the panorex x-ray. Philadelphia Co D Soc. 1962;28:115.

Glickman I. Principios de oclusion. In: Glickman I. Periodontologia clínica. 4ed. México: Interamericana; 1974. p. 808-33.

Goldman HM, Cohen, DW. Anatomia e histologia. In: Goldman HM, Cohen, DW. Periodontia. 6ed. Rio de Janeiro: Guanabara Koogan; 1983. p. 1-56.

Goldreich HN, Martins JCR, Martins LP, Sakima PR. Considerações sobre os erros em cefalometria. Rev Dent Press Ortodon Ortop Facial. 1998;3:81-90.

Graber TM. Extraoral force - facts and fallacies. Am J Orthod. 1955;41:490-505

Graber TM. Postmortems in posttreatment adjustments. Amer J Orthodont. 1966;52(5):311-52.

Graber TM. Panoramic radiography. Angle Orthod. 1966;36(4):293-311.

Graber TM. Panoramic radiography in orthodontic diagnosis. Amer J Orthodont. 1967;53(11):799-821.

Gurgel JA, Almeida RR, Pinzan A. Avaliaçäo comparativa das alteraçöes esqueléticas maxilomandibulares entre jovens, do sexo masculino, tratados ortodonticamente da má oclusäo de Classe II, 1 a divisão e com oclusão normal. R Dental Press Ortodon Ortop Facial. 2001;6(1):39-50.

Harris EF, Vaden JL, Dunn KL, Behrents RG. Effects of patient age on postorthodontic stability in Class II, division 1 malocclusions. Am J Orthod Dentofacial Orthop. 1994;105(1):25-34.

Hatasaka $\mathrm{HH}$. A radiographic study of roots in extraction sites. Angle Orthod. 1976;46(1):64-8.

Hauck RM. Documentation of tooth movement by means of panoral radiography. Am J Orthod. 1970;57(4):386-92. 
Haydar S, Uner O. Comparison of Jones jig molar distalization appliance with extraoral traction. Am J Orthod Dentofacial Orthop. 2000;117(1):49-53.

Henriques JFC, Maltagliati LA, Pinzan A, Freitas MR. Estudo longitudinal das características da má-oclusão de Classe II, 1를 Divisão sem tratamento, em jovens brasileiros, leucodermas, por um período médio de 3 anos e 4 meses. R Dental Press Ortodon Ortop Facial. 1998;3(3):52-66.

Henry R. A classification of Class II, division 1 malocclusion. Angle Orthod. 1957;27(2):83-92.

Herschcopf SA. Class II, Division 2 malocclusion-Nonextraction. Am J Orthod Dentofacial Orthop 1990;97(5):374-80.

Hilgers JJ. The pendulum appliance for Class II non-compliance therapy. J Clin Orthod. 1992;26(11):706-14.

Hitchcock HP. A cephalometric description of Class II, Division 1 malocclusion. Am J Orthod. 1973;63(4):414-23.

Holdaway RA. Bracket angulation as applied to the edgewise appliance. Angle Orthodont. 1952;22(4):227-36.

Houston WJ. The analysis of errors in orthodontic measurements. Am J Orthod. 1983;83(5):382-90.

Interlandi S. Ortodontia mecânica do arco de canto. Introdução à técnica. São Paulo: Sarvier, 1986.

Ishikawa F. Orthodontic applications of panoramic radiography with panorex. J Jap Orthodont Soc. 1968;27(1):151-6.

Itoh T, Tokuda T, Kiyosue S, Hirose T, Matsumoto M, Chaconas SJ. Molar distalization with repelling magnets. J Clin Orthod. 1991;25(10):611-7.

Janson G, Caffer DC, Henriques JF, Freitas MR, Neves LS. Stability of Class II, division 1 treatment with the headgear-activator combination followed by the edgewise appliance. Angle Orthod. 2004;74(5):594-604. 
Johnson BE. Distal movement of the maxillary molar using an active removable appliance and extraoral force: a case report. Quintessence Int. 1994;25(1):43-8.

Johnston LE. Answers in search of quetioners. Am J Orthod Dentofacial Orthop 2002;121(6):552-3.

Jones RD, White JM. Rapid Class II molar correction with an open-coil jig. J Clin Orthod. 1992;26(10):661-4.

Joseph AA, Autchart CJ. An evaluation on the pendulum "distalizing" appliance. Semin Orthod,. 2000;6(2):129-35.

Kane EG. A cephalostat for panoramic radiography. Angle Orthodont. 1967;37(4):325-33.

Karlsen AT. Craniofacial morphology in children with Angle Class II-1 malocclusion with and without deepbite. Angle Orthod. 1994;64(6):437-46.

Keles A, Sayinsu K. A new approach in maxillary molar distalization: intraoral bodily molar distalizer. Am J Orthod Dentofacial Orthop. 2000;117(1):39-48.

Keski-Nisula K, Lehto R, Lusa V, Keski-Nisula L, Varrela J. Occurrence of malocclusion and need of orthodontic treatment in early mixed dentition. Am J Orthod Dentofacial Orthop. 2003;124(6):631-8.

Kinzinger G, Fuhrmann R, Gross U, Diedrich P. Modified pendulum appliance including distal screw and uprighting activation for non-compliance therapy of Class-II malocclusion in children and adolescents. J Orofac Orthop. 2000;61(3):175-90.

Kinzinger G, Pantel C, Ludwig B, Gulden N, Glasl B, Lisson J. Effects of conventional anchorage on premolar root development during treatment with a pendulum appliance. J Orofac Orthop. 2010;71(4):281-9.

Kinzinger GS, Fritz UB, Sander FG, Diedrich PR. Efficiency of a pendulum appliance for molar distalization related to second and third molar eruption stage. Am J Orthod Dentofacial Orthop. 2004;125(1):8-23. 
Kinzinger GS, Gross U, Fritz UB, Diedrich PR. Anchorage quality of deciduous molars versus premolars for molar distalization with a pendulum appliance. Am J Orthod Dentofacial Orthop. 2005;127(3):314-23.

Kite OW. Radiation and image distortion in the Panorex X-ray unit. Oral Surg. 1962;15(10):1201-10.

Klocke A, Nanda RS, Kahl-Nieke B. Skeletal Class II patterns in the primary dentition. Am J Orthod Dentofacial Orthop. 2002;121(6):596-601.

Langland OE, Sippy FH. Anatomic structures as visualized on the orthopantomogram. Oral Surg. 1968;26(4):475-84.

Larheim TA, Svanaes DB. Reproducibility of rotational panoramic radiography: mandibular linear dimensions and angles. Am J Orthod Dentofacial Orthop. 1986;90(1):45-51.

Lee BW. The force requirements for tooth movement. Part II: Uprighting and root torque. Aust Orthod J. 1995;14(1):34-9.

Lehman R, Romuli A, Bakker V. Five-year treatment results with a headgear-activator combination. Eur J Orthod. 1988;10(4):309-18.

Lenz GJ, Woods MG. Incisal changes and orthodontic stability. Angle Orthod. 1999;69(5):424-32.

Litt RA, Nielsen IL. Class II, division 2 malocclusion. To extract--or not extract? Angle Orthod. 1984;54(2):123-38.

Liu YT, Gravely JF. The reliability of the 'Ortho Grid' in cephalometric assessment. $\mathrm{Br}$ J Orthod. 1991;18(1):21-7.

Locatelli R, Bednar J, Dietz VS, Gianelly AA. Molar distalization with superelastic NiTi wire. J Clin Orthod. 1992;26(5):277-9.

Lucchesi MV, Wood RE, Nortje CJ. Suitability of the panoramic radiograph for assessment of mesiodistal angulation of teeth in the buccal segments of the mandible. Am J Orthod Dentofacial Orthop. 1988;94(4):303-10. 
Lund TM, Manson-Hing LR. Relations between tooth positions and focal troughs of panoramic machines. Oral Surg. 1975;40(2):285-93.

Macedo DM, Aidar LAdA. Uso do pêndulo de Hilgers: apresentaçäo de um caso clínico. Rev dent press ortodon ortop maxilar. $2001 ; 6(1): 63-71$.

Mandurino M, Balducci L. Asymmetric distalization with a TMA transpalatal arch. J Clin Orthod. 2001;35(3):174-8.

Martin RA. An analysis of normal cases and Class II, division 1 cases by cephalometric evaluation. Am J Orthod. 1958;44(2):147.

Martinelli FL, de Oliveira Ruellas AC, de Lima EM, Bolognese AM. Natural changes of the maxillary first molars in adolescents with skeletal Class II malocclusion. Am J Orthod Dentofacial Orthop. 2010;137(6):775-81.

Massler M, Frankel JM. Prevalence of malocclusion in children aged 14 to 18 years. Am J Orthod. 1951;37(10):751-68.

Mattila K, Altonen M, Haavikko K. Determination of the gonial angle from the orthopantomogram. Angle Orthod. 1977;47(2):107-10.

Mavropoulos A, Karamouzos A, Kiliaridis S, Papadopoulos MA. Efficiency of noncompliance simultaneous first and second upper molar distalization: a threedimensional tooth movement analysis. Angle Orthod. 2005;75(4):532-9.

Mayoral G. Treatment results with light wires studied by panoramic radiography. Am J Orthod. 1982;81(6):489-97.

Mc Donald FT. The influence of age on patient cooperation in orthodontic treatment. Dent Abstr. 1973;18:52.

McKee IW, Glover KE, Williamson PC, Lam EW, Heo G, Major PW. The effect of vertical and horizontal head positioning in panoramic radiography on mesiodistal tooth angulations. Angle Orthod. 2001;71(6):442-51. 
McKee IW, Williamson PC, Lam EW, Heo G, Glover KE, Major PW. The accuracy of 4 panoramic units in the projection of mesiodistal tooth angulations. Am J Orthod Dentofacial Orthop. 2002;121(2):166-75; quiz 92.

McNamara JA, Jr. Components of class II malocclusion in children 8-10 years of age. Angle Orthod. 1981;51(3):177-202.

Melsen B, Dalstra M. Distal molar movement with Kloehn headgear: is it stable? Am J Orthod Dentofacial Orthop. 2003;123(4):374-8.

Mills CM, McCulloch KJ. Posttreatment changes after successful correction of Class II malocclusions with the twin block appliance. Am J Orthod Dentofacial Orthop. 2000;118(1):24-33.

Mitchell LD. Panoramic roentgenography. J Amer dent Ass. 1963;66:777-86.

Miura F, Mogi M, Ohura Y, Karibe M. The super-elastic Japanese NiTi alloy wire for use in orthodontics. Part III. Studies on the Japanese NiTi alloy coil springs. Am J Orthod Dentofacial Orthop. 1988;94(2):89-96.

Mlynarska-Zduniak E. Angles of inclination of the axes of teeth and the buds of permanent teeth in pantomographs in normal occlusion in the early period of tooth eruption. Czas Stomatol. 1983;36(7):541-6.

Moyers RE, Riolo ML, Guire KE, Wainright RL, Bookstein FL. Differential diagnosis of class II malocclusions. Part 1. Facial types associated with class II malocclusions. Am J Orthod. 1980;78(5):477-94.

Murrell F, Levin P, Kalbfleisch J. Create the space. The pendulum appliance. Ont Dent. 1996;73(3):26-8.

Nashed RR, Reynolds IR. A cephalometric investigation of overjet changes in fifty severe Class II division I malocclusions. Br J Orthod. 1989;16(1):31-7.

Nelsen RJ, Kumpula JW. Panographic radiography. J dent Res. 1952;31(2):159-65.

Nelson B, Hansen K, Hagg U. Overjet reduction and molar correction in fixed appliance treatment of class II, division 1, malocclusions: sagittal and vertical components. Am J Orthod Dentofacial Orthop. 1999;115(1):13-23. 
Nelson BG. Extraoral anchorage in the treatment of Class II, division 1 malocclusions- its possibilities and limitations. Angle Orthod. 1953;23(2):121-33.

Ngantung V, Nanda RS, Bowman SJ. Posttreatment evaluation of the distal jet appliance. Am J Orthod Dentofacial Orthop. 2001;120(2):178-85.

Omblus J, Malmgren O, Pancherz H, Hagg U, Hansen K. Long-term effects of Class II correction in Herbst and Bass therapy. Eur J Orthod. 1997;19(2):185-93.

Oppenheim A. Prognatism from the anthropological and orthodontic viewpoints. Dental Cosmos. 1928;70(12):1170-84.

Otuyemi OD, Jones SP. Long-term evaluation of treated class II division 1 malocclusions utilizing the PAR index. Br J Orthod. 1995;22(2):171-8.

Paatero YV. A new tomographical method for radiographing curved outer surfaces. Acta Radiol. 1948;32:177-84.

Paatero YV. Pantomography in theory and use. Acta Radiol. 1954;41:321-35.

Paatero YV. Pantomography and orthopantomography. Oral Surg. 1961;14(8):94753.

Pancherz $\mathrm{H}$. Relapse after activator treatment. A biometric, cephalometric, and electromyographic study of subjects with and without relapse of overjet. Am J Orthod. $1977 ; 72(5): 499-512$.

Pancherz H, Fackel U. The skeletofacial growth pattern pre- and post-dentofacial orthopaedics. A long-term study of Class II malocclusions treated with the Herbst appliance. Eur J Orthod. 1990;12(2):209-18.

Pancherz H, Zieber K, Hoyer B. Cephalometric characteristics of Class II division 1 and Class II division 2 malocclusions: a comparative study in children. Angle Orthod. 1997;67(2):111-20.

Patel MP, Janson G, Henriques JF, Almeida RR, Freitas MR, Pinzan A, et al. Comparative distalization effects of Jones jig and pendulum appliances. Am J Orthod Dentofacial Orthop 2009;135(3):336-42. 
Peck JL, Sameshima GT, Miller A, Worth P, Hatcher DC. Mesiodistal root angulation using panoramic and cone beam CT. Angle Orthod. 2007;77(2):206-13.

Petridis HP, Tsiggos N, Michail A, Kafantaris SN, Hatzikyriakos A, Kafantaris NM. Three-dimensional positional changes of teeth adjacent to posterior edentulous spaces in relation to age at time of tooth loss and elapsed time. Eur $\mathrm{J}$ Prosthodont Restor Dent. 2010;18(2):78-83.

Phillip RG, Hurst RVV. The cant of the occlusal plane and distortion in the panoramic radiograph. Angle Orthodont. 1978;48(4):317-23.

Phillips JE. Principles and function of the orthopantomograph. Oral Surg. 1967;24(1):41-9.

Picosse M. Oclusão dentária. In: Picosse M. Anatomia dentária. 5ed. São Paulo: Sarvier; 1990. p. 93-110.

Pieringer M, Droschl H, Permann R. Distalization with a Nance appliance and coil springs. J Clin Orthod. 1997;31(5):321-6.

Pinzan-Vercelino CR, Janson G, Pinzan A, de Almeida RR, de Freitas MR, de Freitas KM. Comparative efficiency of Class II malocclusion treatment with the pendulum appliance or two maxillary premolar extractions and edgewise appliances [corrected]. Eur J Orthod. 2009;31(3):333-40.

Pirttiniemi P, Kantomaa T, Mantysaari R, Pykalainen A, Krusinskiene V, Laitala T, et al. The effects of early headgear treatment on dental arches and craniofacial morphology: an 8 year report of a randomized study. Eur J Orthod. 2005;27(5):42936.

Proffit WR. Forty-year review of extraction frequencies at a university orthodontic clinic. Angle Orthod. 1994;64(6):407-14.

Renfroe EW. Construction of the basic appliance. In: Renfroe EW. Edgewise. Philadelphia: Lea \& Febiger; 1975. p. 65-125.

Richardson JE, Langland OE, Sippy FH. A cephalostat for the orthopantomograph. Oral Surg Oral Med Oral Pathol. 1969;27(5):643-6. 
Roberts WE, Marshall KJ, Mozsary PG. Rigid endosseous implant utilized as anchorage to protract molars and close an atrophic extraction site. Angle Orthod. 1990;60(2):135-52.

Rondeau BH. The pendulum appliance. J Gen Orthod. 1995;6(1):22-30.

Rosemblum R. Class II malocclusion: mandibular retrusion or maxillary protrusion? Angle Orthod. 1995;65(1):49-62.

Roth RH. Functional occlusion for the Orthodontist. Part III. J Clin Orthod. 1981;15(3):174-9, 82-98.

Roth $\mathrm{RH}$. The straight-wire appliance 17 years later. J Clin Orthod. 1987;21(9):63242.

Rowse CW. Notes on interpretation of the orthopantomogram. Br Dent J. $1971 ; 130(10): 425-34$.

Runge ME, Martin JT, Bukai F. Analysis of rapid maxillary molar distal movement without patient cooperation. Am J Orthod Dentofacial Orthop. 1999;115(2):153-7.

Rushton VE, Horner K, Worthington HV. The quality of panoramic radiographs in a sample of general dental practices. Br Dent J. 1999;186(12):630-3.

Samawi SS, Burke PH. Angular distortion in the orthopantomogram. Br J Orthod. 1984;11(2):100-7.

Sandler PJ. Reproducibility of cephalometric measurements. Br J Orthod. 1988;15(2):105-10.

Santos ECA, Silva Filho OG, Reis PMP, Bertoz APM. Distalização dos molares superiores com aparelho Pendex: estudo cefalométrico prospectivo. R Dental Press Ortodon Ortop Facial. 2007;12(4):49-62.

Santos ECA, Silva Filho OGd, Reis PMP, Bertoz FA. Distalização dos molares superiores com aparelho Pendex: Avaliação mediante radiografia panorâmica. J Bras ortodon ortop facial. 2006;11(64):355-62. 
Santos MAC. Caracterização cefalométrica da Classe II, 1divisão, esquelética [dissertação]. Bauru (SP): Faculdade de Odontologia de Bauru, Universidade de São Paulo; 2003.

Sassouni V. The Class II syndrome: differential diagnosis and treatment. Angle Orthod. 1970;40(4):334-41.

Scott Conley R, Jernigan C. Soft tissue changes after upper premolar extraction in Class II camouflage therapy. Angle Orthod. 2006;76(1):59-65.

Sella RC, Mendonça MR, Cuoghi OA. Avaliação ortopantomográfica das angulações mesiodistais de caninos, pré-molares e molares inferiores com e sem a presença dos terceiros molares. Rev dent press ortodon ortopedi facial. 2009;14(6):97-108.

Servoss JM. Classification of occlusion. ASDC J Dent Child. 1975;42(1):28-30.

Sfondrini MF, Cacciafesta V, Sfondrini G. Upper molar distalization: a critical analysis. Orthod Craniofac Res. 2002;5(2):114-26.

Sicher H, Dubrul EL. The víscera of head and neck. In: Sicher H, Dubrul EL. Oral anatomy. $5^{\text {th }}$ ed. Saint Louis: Mosby; 1970. p. 174-296.

Silva Filho OG, Cavassan AO, Freitas SF. Oclusão: escolares de Bauru. Prevalência de oclusão normal e má oclusão na dentadura mista em escolares da cidade de Bauru (SP). Rev Ass Paul Cirurg Dent. 1989;43(6):287-90.

Silva Filho OG, Santos ECA, Silva APJL, Bertoz APM. Distalização dos molares superiores com aparelho Pendex unilateral: estudo piloto com radiografia panorâmica. R Dental Press Ortodon Ortop Facial. 2007;12(1):56-66.

Southard TE, Behrents RG, Tolley EA. The anterior component of occlusal force. Part 2. Relationship with dental malalignment. Am J Orthod Dentofacial Orthop. 1990;97(1):41-4.

Southard TE, Southard KA, Tolley EA. Periodontal force: a potential cause of relapse. Am J Orthod Dentofacial Orthop. 1992;101(3):221-7. 
Stramotas S, Geenty JP, Petocz P, Darendeliler MA. Accuracy of linear and angular measurements on panoramic radiographs taken at various positions in vitro. Eur $\mathrm{J}$ Orthod. 2002;24(1):43-52.

Strang RHW. Factors associated with successful orthodontic treatment. Amer J Orthodont. 1952;38(10):790-800.

Strang RHW. Tratado de ortodoncia. Buenos Aires: Editorial Bibliográfica Argentina; 1957.

Taner TU, Yukay F, Pehlivanoglu M, Cakirer B. A comparative analysis of maxillary tooth movement produced by cervical headgear and pend-x appliance. Angle Orthod. 2003;73(6):686-91.

Tavano O, Ursi WJS, Almeida RR, Henriques JFC. Determinação de linhas de referência para medições angulares em radiografias ortopantomográficas. Odontol. mod. 1989;16(9):22-5.

Toroglu M, Uzel I, Cam O, Hancioglu Z. Cephalometric evaluation of the effects of pendulum appliance on various vertical growth patterns and of the changes during short-term stabilization. Clin Orthod Res. 2001;4(1):15-27.

Tsai HH. Eruption process of the second molar. ASDC J Dent Child. 2000;67(4):27581.

Tulloch JF, Medland W, Tuncay OC. Methods used to evaluate growth modification in Class II malocclusion. Am J Orthod Dentofacial Orthop. 1990;98(4):340-7.

Tuverson DL. Anterior interocclusal relations. Part I. Am J Orthod. 1980;78(4):36170.

Unde MD, Sadowsky C, BeGole EA. Long-term stability of dental relationships after orthodontic treatment. Angle Orthod. 1983;53(3):240-52.

Ursi W, Almeida GA. Cooperação mínima utilizando o pêndulo de Hilgers. Rev dent press ortodon ortop maxilar. 2002;7(2):87-123.

Ursi WJS, Almeida RR, Tavano O, Henriques JF. Assessment of mesiodistal axial inclination through panoramic radiography. J Clin Orthod. 1990;24(3):166-73. 
Ursi WJS. Avaliação das inclinações axiais mesiodistais dos dentes superiores e inferiores, em uma amostra de oclusão normal, não tratada ortodonticamente, utilizando radiografias ortopantomográficas obtidas em diferentes aparelhos [dissertação]. Bauru (SP): Faculdade de Odontologia de Bauru, Universidade de São Paulo; 1989.

Valarelli F. Relação entre o grau de severidade e o sucesso do tratamento sem extração da má oclusão de Classe II [tese]. Bauru (SP): Faculdade de Odontologia de Bauru, Universidade de São Paulo; 2006.

Vale DM, Martins DR. Avaliação cefalométrica das estruturas dento-esqueléticas em jovens portadores de Classe II, divisão 1, brasileiros, leucodermas e de origem mediterrânea. Ortodontia. 1987;20(1/2):5-17.

Valladares-Neto J, Domingues MHMS, Capellozza-Filho L. Pesquisa em ortodontia: bases para a produção e a análise crítica. Rev Dent Press Ortod Ortop Facial. 2000;5(4):89-105.

Vardimon AD, Beckmann S, Shpack N, Sarne O, Brosh T. Posterior and anterior components of force during bite loading. J Biomech. 2007;40(4):820-7.

Vigorito JW. Estudo comparativo de algumas características mandibulares em maloclusões de Classe I e Classe II, divisão 1, de Angle. Rev Fac Odont USP. 1973;11(1):75-82.

Vigorito JW. Introdução à mecânica ortodôntica com aparelhos fixos. In: Vigorito JW. Ortodontia clínica preventiva. São Paulo: Panamed; 1984. p. 255-93.

Weber FN. Clinical investigations related to use of the Begg technique at the University of Tennessee. Am J Orthod. 1971;59(1):24-36.

Weiland FJ. The role of occlusal discrepancies in the long-term stability of the mandibular arch. Eur J Orthod. 1994;16(6):521-9.

Wheeler RC. The arrangement of the teeth and occlusion. In: Wheeler RC. A textbook of dental anatomy and physiology. 4th ed. Philadelphia: Saunders Company; 1965. p. 365-412. 
Wheeler TT, McGorray SP, Dolce C, Taylor MG, King GJ. Effectiveness of early treatment of Class II malocclusion. Am J Orthod Dentofacial Orthop. 2002;121(1):917.

Williams R. Eliminating lower retention. J Clin Orthod. 1985;19(5):342-9.

Wilson WL. Modular orthodontic systems. Part 2. J Clin Orthod. 1978a;12(5):358-75.

Wilson WL. Modular orthodontic systems. Part 1. J Clin Orthod. 1978b;12(4):259-67, 70-8.

Woods M, Lee D, Crawford E. Finishing occlusion, degree of stability and the PAR index. Aust Orthod J. 2000;16(1):9-15.

Yavari J, Shrout MK, Russell CM, Haas AJ, Hamilton EH. Relapse in Angle Class II Division 1 Malocclusion treated by tandem mechanics without extraction of permanent teeth: A retrospective analysis. Am J Orthod Dentofacial Orthop. 2000;118(1):34-42.

Young J. Outline of oral and dental anatomy. New York: McGraw-Hill; 1964. 
Apênalices 



\section{APÊNDICES}

APÊNDICE 1 - Características dos pacientes - gênero e idades cronológicas

\begin{tabular}{|r|l|l|l|r|r|r|r|r|}
\hline No & Pacientes & Gênero & Tipo da Classe II & Idade Inicial & Idade Final & $\begin{array}{r}\text { Idade Pós- } \\
\text { Tratamento }\end{array}$ & $\begin{array}{r}\text { Tempo } \\
\text { Tratamento }\end{array}$ & $\begin{array}{r}\text { Tempo Pós- } \\
\text { Tratamento }\end{array}$ \\
\hline 1 & A. O. & F & Divisão 1 & 13,14 & 16,90 & 22,76 & 3,76 & 5,85 \\
\hline 2 & A. V. & F & Divisão 1 & 14,25 & 17,61 & 22,60 & 4,29 & 4,99 \\
\hline 3 & A. L. & F & Divisão 1 & 14,78 & 21,50 & 26,52 & 6,71 & 5,03 \\
\hline 4 & A. G. & F & Divisão 1 & 14,85 & 19,07 & 23,14 & 4,21 & 4,07 \\
\hline 5 & B. F. & M & Divisão 1 & 11,35 & 15,34 & 21,02 & 3,99 & 5,68 \\
\hline 6 & C. T. & F & Divisão 1 & 16,21 & 19,77 & 24,95 & 3,55 & 5,18 \\
\hline 7 & C. G. & F & Divisão 1 & 17,02 & 21,86 & 28,05 & 4,83 & 6,19 \\
\hline 8 & C. R. & M & Divisão 1 & 14,48 & 18,95 & 23,49 & 4,47 & 4,54 \\
\hline 9 & F. G. & M & Divisão 1 & 13,95 & 18,36 & 25,68 & 4,41 & 7,32 \\
\hline 10 & F. O. & M & Divisão 1 & 16,99 & 20,68 & 27,19 & 3,69 & 6,50 \\
\hline 11 & H. C. & M & Divisão 1 & 12,00 & 15,12 & 21,17 & 3,12 & 6,05 \\
\hline 12 & L. P. & F & Divisão 1 & 14,86 & 18,19 & 23,43 & 3,33 & 5,23 \\
\hline 13 & L. I. & F & Divisão 1 & 13,24 & 18,19 & 24,65 & 4,95 & 6,46 \\
\hline 14 & M. V. & F & Divisão 1 & 12,68 & 17,74 & 22,39 & 5,06 & 4,65 \\
\hline 15 & M. O. & F & Divisão 1 & 14,78 & 18,67 & 24,96 & 3,89 & 6,29 \\
\hline 16 & R. O. & F & Divisão 1 & 13,06 & 17,50 & 22,07 & 4,44 & 4,58 \\
\hline 17 & R. S. & F & Divisão 1 & 11,92 & 16,91 & 21,02 & 4,99 & 4,11 \\
\hline 18 & S. B. & F & Divisão 1 & 14,48 & 18,77 & 21,98 & 4,28 & 3,22 \\
\hline 19 & T. G. & F & Divisão 1 & 15,84 & 20,00 & 24,83 & 4,16 & 4,83 \\
\hline
\end{tabular}


APÊNDICE 2 - Valores amostrais, em graus, das inclinações axiais mesiodistais dos dentes avaliados, nos períodos inicial, final e 5 anos após o tratamento.

\begin{tabular}{|c|c|c|c|c|c|c|c|c|c|c|c|c|}
\hline $\mathrm{N}^{\circ}$ & $\mathrm{T} 1$ & $\mathrm{~T} 2$ & $\mathrm{~T} 3$ & $\mathrm{~T} 1$ & $\mathrm{~T} 2$ & $\mathrm{~T} 3$ & $\mathrm{~T} 1$ & $\mathrm{~T} 2$ & $\mathrm{~T} 3$ & $\mathrm{~T} 1$ & $\mathrm{~T} 2$ & $\mathrm{~T} 3$ \\
Pacientes & $1 \mathrm{MD}$ & $1 \mathrm{MD}$ & $1 \mathrm{MD}$ & $1 \mathrm{ME}$ & $1 \mathrm{ME}$ & $1 \mathrm{ME}$ & $2 \mathrm{MD}$ & $2 \mathrm{MD}$ & $2 \mathrm{MD}$ & $2 \mathrm{ME}$ & $2 \mathrm{ME}$ & $2 \mathrm{ME}$ \\
\hline 1 & 95 & 96 & 92 & 94 & 100 & 99 & 111 & 110 & 111 & 107 & 110 & 106 \\
\hline 2 & 93 & 105 & 96 & 93 & 106 & 98 & 109 & 118 & 108 & 111 & 115 & 110 \\
\hline 3 & 97 & 110 & 104 & 109 & 101 & 99 & 112 & 113 & 116 & 121 & 114 & 119 \\
\hline 4 & 96 & 100 & 91 & 100 & 99 & 96 & 105 & 114 & 120 & 102 & 113 & 117 \\
\hline 5 & 97 & 96 & 95 & 103 & 99 & 87 & 104 & 100 & 95 & 111 & 105 & 99 \\
\hline 6 & 95 & 102 & 99 & 91 & 91 & 98 & 113 & 112 & 112 & 105 & 110 & 109 \\
\hline 7 & 90 & 105 & 102 & 96 & 106 & 103 & 102 & 124 & 126 & 106 & 124 & 125 \\
\hline 8 & 103 & 103 & 104 & 95 & 95 & 100 & 114 & 105 & 108 & 108 & 99 & 101 \\
\hline 9 & 93 & 89 & 88 & 95 & 97 & 90 & 102 & 103 & 101 & 105 & 110 & 99 \\
\hline 10 & 90 & 95 & 98 & 92 & 96 & 99 & 102 & 100 & 103 & 101 & 103 & 104 \\
\hline 11 & 94 & 101 & 93 & 96 & 104 & 95 & 106 & 107 & 97 & 110 & 107 & 101 \\
\hline 12 & 100 & 100 & 91 & 103 & 98 & 91 & 114 & 118 & 114 & 114 & 117 & 115 \\
\hline 13 & 93 & 96 & 96 & 100 & 99 & 91 & 115 & 118 & 115 & 112 & 112 & 112 \\
\hline 14 & 100 & 96 & 95 & 90 & 97 & 89 & 118 & 108 & 104 & 109 & 111 & 100 \\
\hline 15 & 83 & 91 & 95 & 79 & 90 & 93 & 107 & 110 & 109 & 100 & 102 & 105 \\
\hline 16 & 90 & 107 & 92 & 92 & 100 & 86 & 95 & 109 & 94 & 98 & 108 & 90 \\
\hline 17 & 101 & 102 & 96 & 102 & 102 & 100 & 119 & 109 & 109 & 118 & 115 & 110 \\
\hline 18 & 98 & 96 & 94 & 88 & 96 & 96 & 115 & 107 & 109 & 106 & 110 & 110 \\
\hline 19 & 94 & 97 & 94 & 95 & 100 & 91 & 110 & 110 & 108 & 112 & 111 & 105 \\
\hline 20 & 87 & 92 & 90 & 78 & 96 & 84 & 89 & 93 & 96 & 80 & 89 & 85 \\
\hline
\end{tabular}


Anexo 



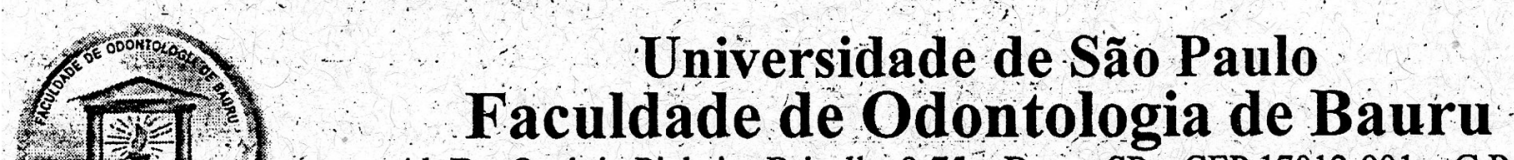

Al. Dr. Octávio Pinheiro Brisolla, 9-75 - Bauru-SP-CEP 17012-901 - C.P. 73

PABX (0XX14)3235-8000 - FAX (0XX14)3223-4679

Comitê de Ética em Pesquisa (14)3235-8356

e-mail: mferrari@fob.usp.br

Processo n9 081/2009

Bauru, 30 de junho de 2009.

Senhor Professor,

o projeto de pesquisa encaminhadó a este Comitê de Ética em Pesquisa em Seres Humanos, denominado "Análise longitudinal por meio de radiografias panorâmicas do tratamento da Classe II utilizando o distalizador intrabucal Pendulum, seguido do aparelho fixo", de autoria de Caroline Andrade Rocha, que será desenvolvido sob sua orientação, foi enviado ao relator para avaliação.

Na reunião de 24 de junho de 2009 o parecer do relator, aprovando o projeto, foi aceito pelo Comitê, , considerando quie não existem infrações éticas pendentes.

Informamos que qualquer álteração efetuada no trabalho de pesquisa, o pesquisador/órientador deverá comunicar ao CEP-FOB/USP, bem como ao final do trabalho enviar um Relatório para novo parecer, o qual será utilizado para publicação científica.

Atenciosamente,

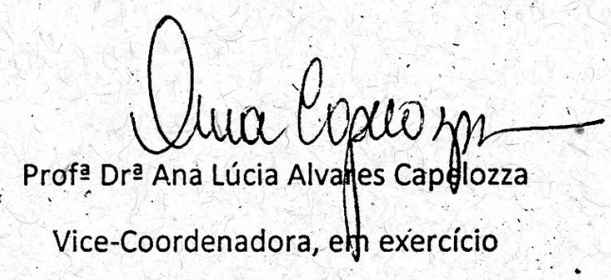

Prof. Dr. Renato Rodrigues de Almeida 


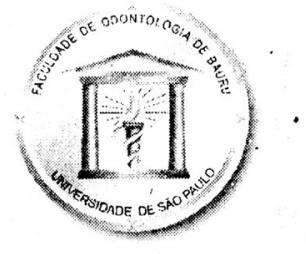

Proc. CEP no 081/2009

Bauru, 30 de novembro de 2010.

\section{Universidade de São Paulo \\ Faculdade de Odontologia de Bauru}

Al. Dr. Octávio Pinheiro Brisolla, 9-75 - Bauru-SP - Brasil-CEP 17012-901 - C.P. 73 PABX (0XX14)3.235-8000 - FAX (0XX14)3223-4679

Camitê de Ética em Pesquisa (14)3235-8356 e-mail: mferrari@fob.usp.br

Senhor Professor,

Informamos Vossa Senhoria que após análise por um Relatọr deste Comitê de Ética em Pesquisa, ó relatório final cio trabalho de pesquisa "Análise longitudinal por meio de radiografias panorâmicas do tratamento da Classe II utilizando o distalizador intrabucal Pendulum", seguido do aparelho fixo, de autoria de Caroline Andrade Rocha, sob sua orientação foi APROVADO em reunião deste Comitê, realizada no dia $\mathbf{2 4}$ de novembro de $\mathbf{2 0 1 0}$, bem como a alteração do título para Avaliação longitudinal da inclinação axial mesiodistal dos molares superiores decorrente do uso do aparelho Pendulum associado ao aparelho fixo por meio de radiografias panorâmicas, considerando não haver impedimentos éticos.

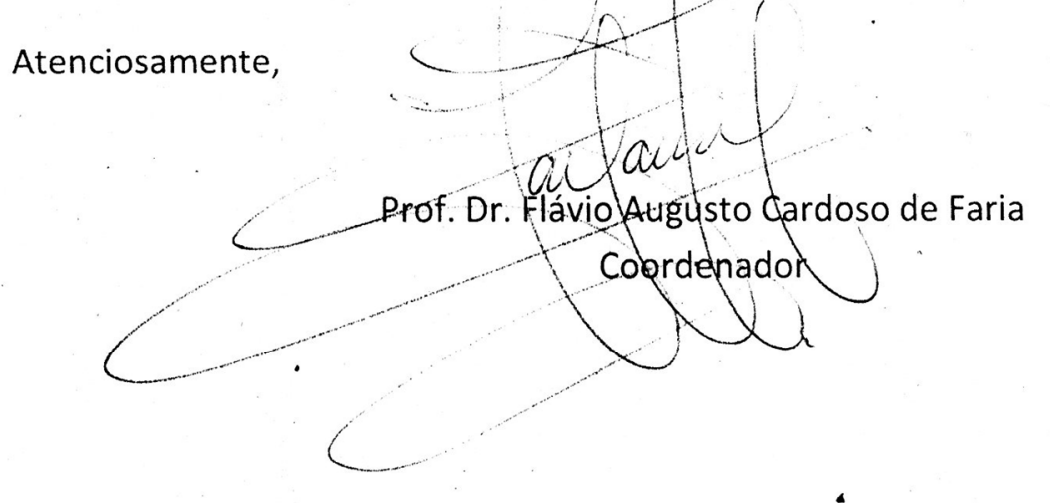

Prof. Dr. Renato Rodrigues de Almeida

Docente do Departamento de Odontopediatria, Ortodontia e Saúde Coletiva 